\title{
PRELIMINARY FIELD EVALUATION OF MERCURY CONTROL USING COMBUSTION MODIFICATIONS
}

Final Report

\section{DOE Contract No. DE-FC26-03NT41725}

\author{
January 23, 2003 - January 22, 2005 \\ Dr. P. Botros \\ U.S. DOE Contracting Office Representative
}

\author{
Prepared by: \\ V. Lissianski, P. Maly, and T. Marquez
}

February 17, 2005

Submitted by:

GE Energy

Energy and Environmental Research Corporation (EER)

18 Mason, Irvine, CA 92618 


\section{$\underline{\text { Disclaimer }}$}

This report was prepared as an account of work sponsored by an agency of the United States Government. Neither the United States nor any agency thereof, nor any of their employees, makes any warranty, express or implied, or assumes any legal liability or responsibility for the accuracy, completeness, or usefulness of any information, apparatus, product, or process disclosed, or represents that its use would not infringe privately owned rights. Reference herein to any specific commercial product, process, or service by trade name, trademark, manufacturer, or otherwise does not necessarily constitute or imply its endorsement, recommendation, or favoring by the United States Government or any agency thereof. The views and opinions of authors expressed herein do not necessarily state or reflect those of the United States Government or any agency thereof. 


\begin{abstract}
In this project EER conducted a preliminary field evaluation of the integrated approach for mercury $(\mathrm{Hg})$ and $\mathrm{NO}_{\mathrm{x}}$ control. The approach enhanced the "naturally occurring" $\mathrm{Hg}$ capture by fly ash through combustion optimization, increasing carbon in ash content, and lowering ESP temperature. The evaluation took place in Green Station Units 1 and 2 located near Henderson, Kentucky and operated by Western Kentucky Energy. Units 1 and 2 are equipped with cold-side ESPs and wet scrubbers. Green Station Units 1 and 2 typically fire two types of fuel: a bituminous coal and a blend of bituminous coals based on availability.

Testing of $\mathrm{Hg}$ emissions in Unit 2 without reburning system in operation and at minimum OFA demonstrated that efficiencies of $\mathrm{Hg}$ reduction downstream of the ESP were $30-40 \%$. Testing also demonstrated that OFA system operation at $22 \%$ air resulted in $10 \%$ incremental increase in $\mathrm{Hg}$ removal efficiency at the ESP outlet. About $80 \%$ of $\mathrm{Hg}$ in flue gas at ESP outlet was present in the oxidized form.

Testing of $\mathrm{Hg}$ emissions under reburning conditions showed that $\mathrm{Hg}$ emissions decreased with LOI increase and ESP temperature decrease. Testing demonstrated that maximum $\mathrm{Hg}$ reduction downstream of ESP was $40-45 \%$ at ESP temperatures higher than $300^{\circ} \mathrm{F}$ and $60-80 \%$ at ESP temperatures lower than $300^{\circ} \mathrm{F}$. The program objective to demonstrate $80 \% \mathrm{Hg}$ removal at the ESP outlet has been met.
\end{abstract}




\section{Table of Contents}

Section

$\underline{\text { Page }}$

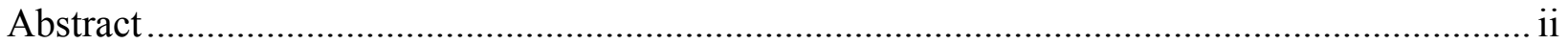

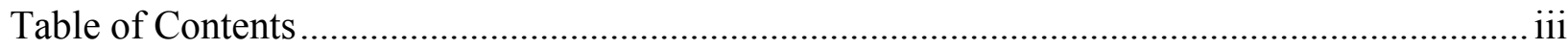

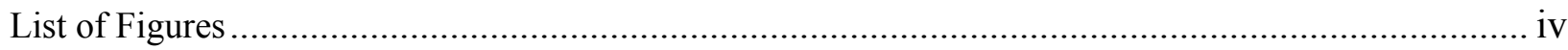

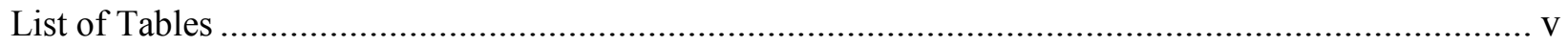

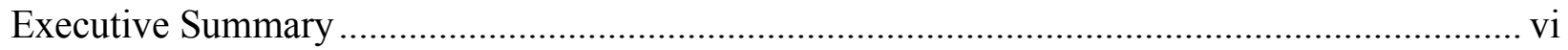

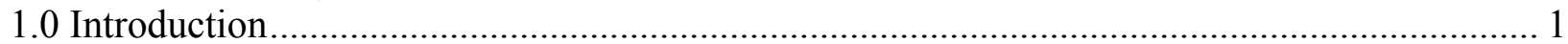

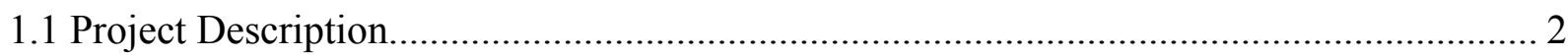

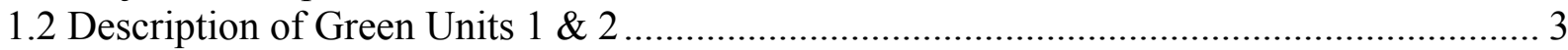

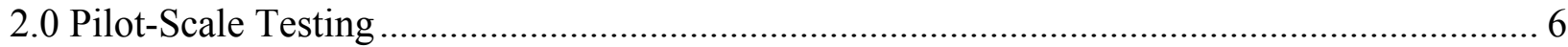

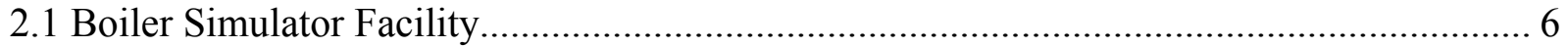

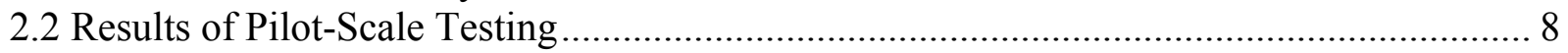

3.0 Testing of Baseline Mercury Emissions ....................................................................... 14

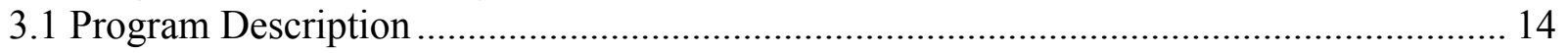

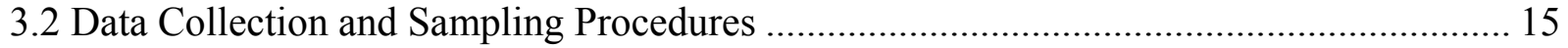

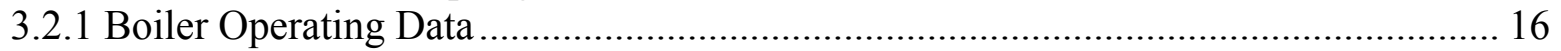

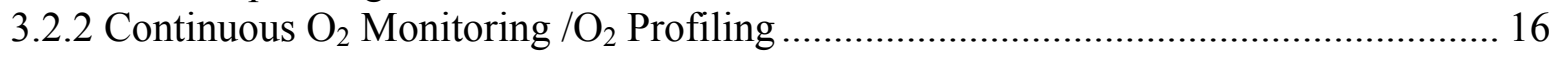

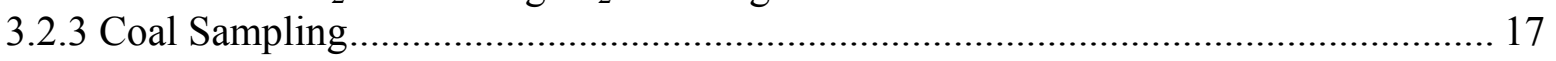

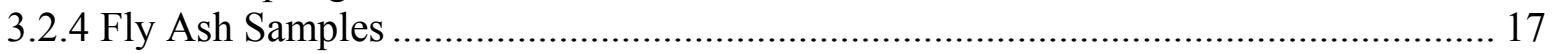

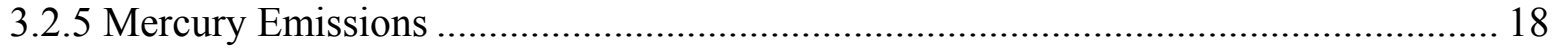

3.3 Comparison of Pilot-Scale and Baseline Measurements ............................................... 21

4.0 Mercury Emissions In Unit 2 Under Reburning Conditions ............................................. 25

4.1 Mercury Emissions in Unit 2 In Reburning ........................................................ 25

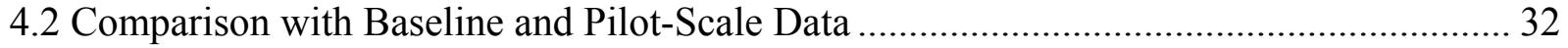

5.0 Mercury Emissions In Unit 1 Under Reburning Conditions ............................................ 34

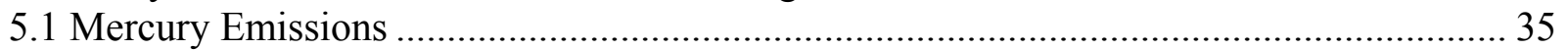

5.2 Comparison With Previously Obtained Data............................................................. 38

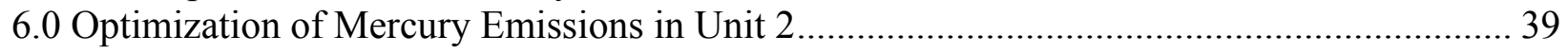

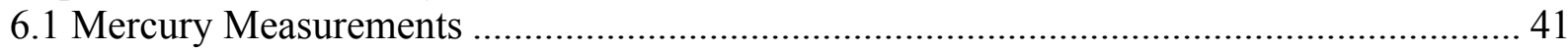

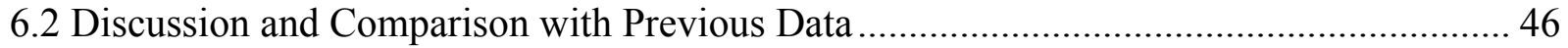

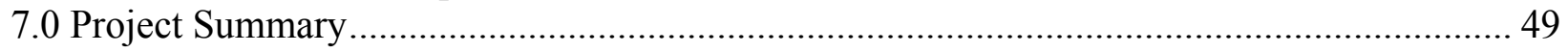

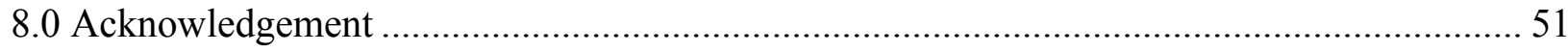

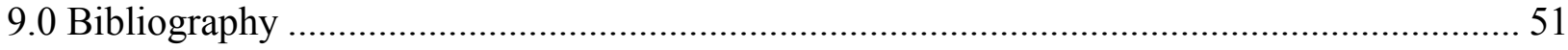

Attachment I. Fuel Composition and Plant Data ......................................................... . I 


\section{List of Figures}

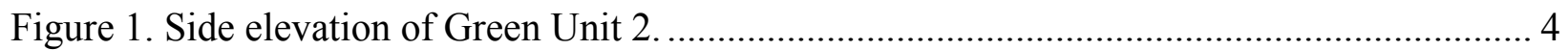

Figure 2. Reburning system on Green Unit 2............................................................... 5

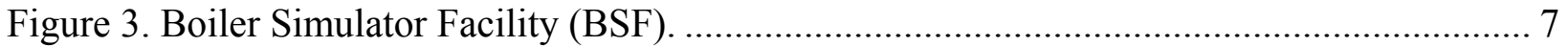

Figure 4. Axial temperature profiles in BSF and WKE Green Unit 2 .................................... 8

Figure 5. Mercury removal (a) and $\mathrm{Hg}$ emissions (b) as a function of LOI at air staging.............. 9

Figure 6. Mercury removal (a) and $\mathrm{Hg}$ emissions (b) as a function of LOI at reburning conditions at ESP temperatures of $310-360^{\circ} \mathrm{F}$........................................................................... 10

Figure 7. Mercury removal for coal 1 at reburning conditions at different ESP temperatures as a function of LOI. Data obtained by Consol on re-injection of high carbon fly ash are also shown.

Figure 8. Effect of ESP temperature on Hg removal. Filled symbols represent present data, open symbols Consol data, lines correlation predictions.

Figure 9. Mercury removal (a) and Hg emissions (b) in reburning as a function of LOI. ESP

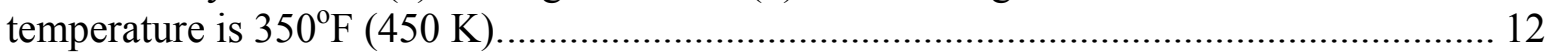

Figure 10. Predicted effect of temperature and LOI on $\mathrm{Hg}$ removal (solid lines). Numbers indicate level of mercury removal. .................................................................................. 12

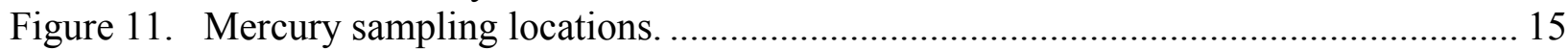

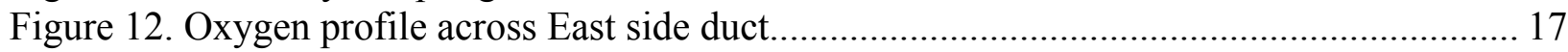

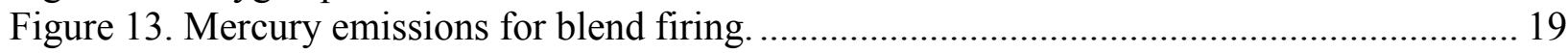

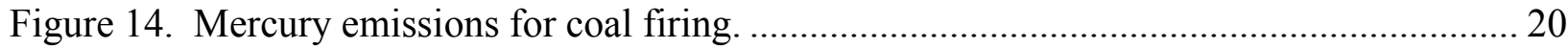

Figure 15. Mercury removal efficiencies (a) and $\mathrm{Hg}$ emissions (b) for coal firing. ..................... 21

Figure 16. Mercury removal efficiencies (a) and Hg emissions (b) for blend firing.................... 21

Figure 17. Comparison of pilot- (open symbols) and full-scale (filled symbols) data for OFA

tests for $\mathrm{Hg}$ removal efficiency (a) and $\mathrm{Hg}$ emissions (b) for coal firing............................ 22

Figure 18. Comparison of pilot- (open symbols) and full-scale (filled symbols) data for OFA tests for $\mathrm{Hg}$ removal efficiency (a) and $\mathrm{Hg}$ emissions (b) for blend firing........................... 22

Figure 19. Mercury partition in full- and pilot-scale tests for coal firing.................................... 23

Figure 20. Mercury partition in full- and pilot-scale tests for blend firing.................................. 23

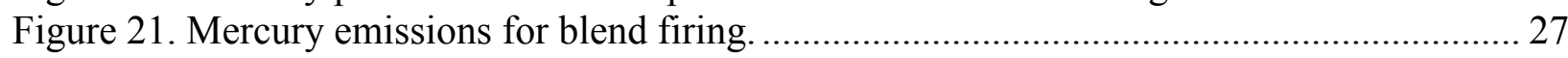

Figure 22. Mercury emissions at ESP inlet for coal firing. ......................................................... 28

Figure 23. Mercury emissions at ESP outlet for coal firing. ...................................................... 28

Figure 24. Mercury emissions at the stack for coal firing. ........................................................ 29

Figure 25. Mercury removal efficiencies for blend firing. ........................................................ 29

Figure 26. Mercury removal efficiencies (a) and Hg emissions (b) for coal firing. ...................... 30

Figure 27. Effect of temperature on $\mathrm{Hg}$ removal (a) and $\mathrm{Hg}$ emissions (b) for coal firing. .......... 30

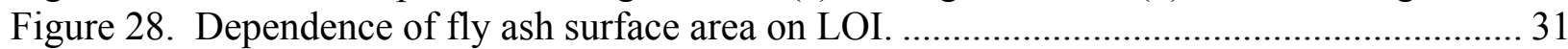

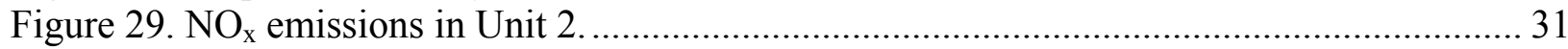

Figure 30. Comparison of $\mathrm{Hg}$ removal efficiencies measured in pilot- scale, baseline testing and reburning for coal firing

Figure 31. Comparison of $\mathrm{Hg}$ removal efficiencies (a) and $\mathrm{Hg}$ emissions (b) measured in pilotscale, baseline testing and in reburning for blend firing.................................................... 33

Figure 32. FAMS (filled bars) and FSTM (open bars) results for total Hg at ESP outlet............ 36

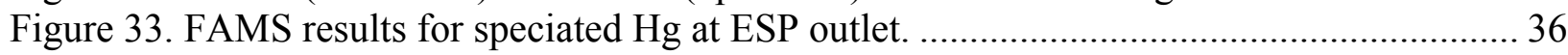

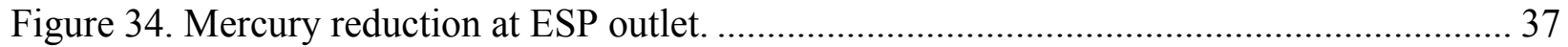


Figure 35. Mercury emissions at ESP outlet. 37

Figure 36. Comparison of pilot-scale and data on $\mathrm{Hg}$ removal (a) and $\mathrm{Hg}$ emissions (b) in

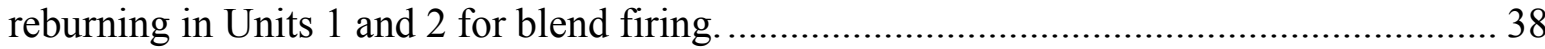

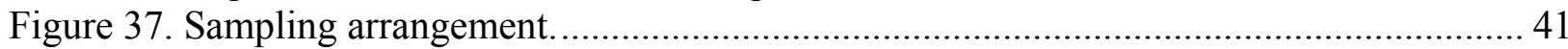

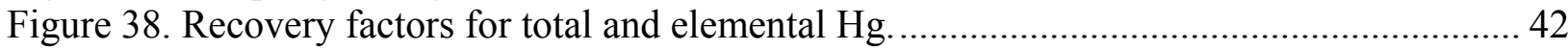

Figure 39. Results of CEM measurements for blend firing on September 20-24.................... 43

Figure 40. Mercury reduction efficiencies (a) and $\mathrm{Hg}$ emissions (b) during testing on September 20-24. 44

Figure 41. Results of CEM measurements for coal firing on September 24-27...................... 44

Figure 42. Mercury reduction efficiencies (a) and $\mathrm{Hg}$ emissions for coal firing....................... 45

Figure 43. Mercury reduction efficiencies (a) and $\mathrm{Hg}$ emissions (b) at the stack for coal firing. 46

Figure 44. Dependence of $\mathrm{Hg}$ removal efficiency on temperature for blend firing. .................. 47

Figure 45. Dependence of $\mathrm{Hg}$ removal efficiency on temperature for coal firing..................... 47

Figure 46. Dependence of $\mathrm{Hg}$ concentration in fly ash on fly ash surface area. ....................... 48

\section{Table}

\section{List of Tables}

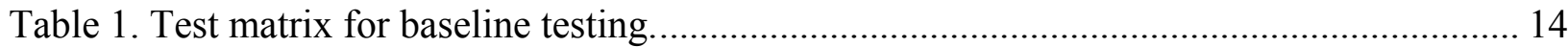

Table 2. Summary of baseline tests for ESP inlet duct...................................................... 18

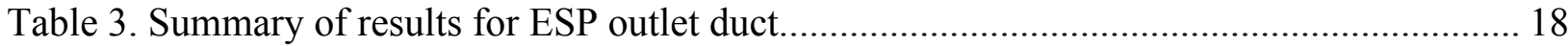

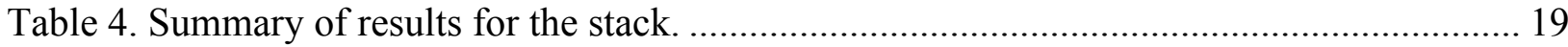

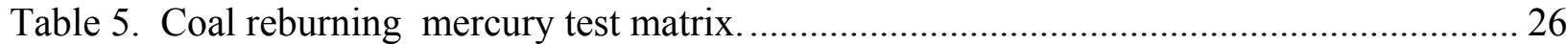

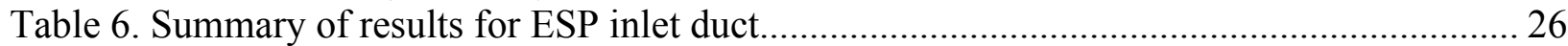

Table 7. Summary of results for ESP outlet duct................................................................... 27

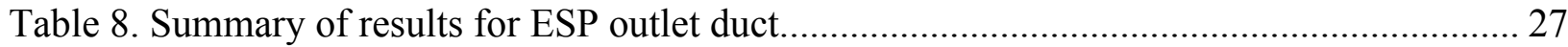

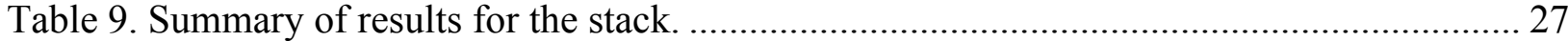

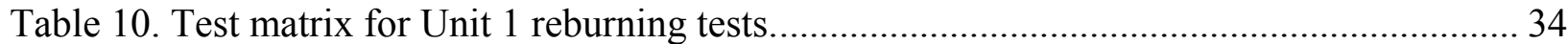

Table 11. Results of mercury measurements. .............................................................. 35

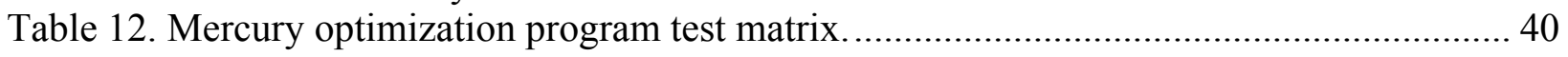

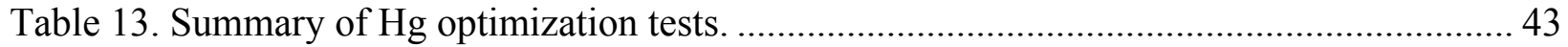




\section{Executive Summary}

In this project EER conducted a preliminary field evaluation of the integrated approach for mercury $(\mathrm{Hg})$ and $\mathrm{NO}_{\mathrm{x}}$ control. The integrated $\mathrm{Hg} / \mathrm{NO}_{\mathrm{x}}$ control method utilized coal reburning (injection of reburning coal and overfire air) and ESP optimization. The approach enhanced the "naturally occurring" $\mathrm{Hg}$ capture by fly ash through combustion optimization, increasing carbon in ash content, and lowering ESP temperature. Another benefit of the approach includes reduced $\mathrm{NO}_{\mathrm{x}}$ emissions.

The evaluation took place in Green Station Units 1 and 2 located near Henderson, Kentucky and operated by Western Kentucky Energy. Units 1 and 2 are sister units with similar boiler parameters and unit configurations. They are equipped with cold-side ESPs and a wet scrubber. Green Station Units 1 and 2 typically fire two types of fuel: a bituminous coal and a blend of bituminous coals based on availability. Mercury content in coal blend is typically lower than that in the individual coal.

The approach to optimizing reburning for $\mathrm{Hg}$ control included pilot-scale testing to determine effects of process conditions and fuel composition on $\mathrm{Hg}$ removal, engineering evaluation to determine optimum boiler operation conditions for $\mathrm{Hg}$ removal, and a Unit 2 optimization test program for $\mathrm{Hg}$ control.

The program focused on optimizing combustion conditions and ESP temperature to maximize $\mathrm{Hg}$ reduction across the ESP. The ESP temperature was decreased by decreasing unit load. The project goal was to demonstrate $80 \% \mathrm{Hg}$ control downstream of the ESP.

Testing of $\mathrm{Hg}$ emissions in Unit 2 without reburning system in operation and at minimum OFA demonstrated that $\mathrm{Hg}$ reductions downstream of ESP for coal and blend firing were 3040\%. Mercury emissions at the ESP outlet were 5.8-6.9 lb/TBtu and 2.7-3.7 lb/TBtu for coal and blend firing, respectively. Testing demonstrated that OFA system operation at 22\% air resulted in $10 \%$ incremental increase in $\mathrm{Hg}$ removal efficiency at ESP outlet. About $80 \%$ of $\mathrm{Hg}$ in flue gas at ESP outlet was present in the oxidized form.

Pilot-scale testing in a $300 \mathrm{~kW}$ Boiler Simulator Facility was conducted to determine effects of process conditions and fuel composition on $\mathrm{Hg}$ removal. Testing focused on determining effects of the following factors on $\mathrm{Hg}$ removal: (a) fuel composition, (b) carbon in ash content (also characterized as Loss On Ignition, or LOI), and (c) ESP temperature. Testing demonstrated that $\mathrm{Hg}$ removal improved with LOI increase and ESP temperature decrease. 
Results of pilot-scale testing suggested that $80 \% \mathrm{Hg}$ control at ESP outlet could be achieved at LOI $\geq 8 \%$ and ESP temperatures $\leq 300^{\circ} \mathrm{F}$.

Testing of $\mathrm{Hg}$ emissions in Units 1 and 2 under reburning conditions confirmed that $\mathrm{Hg}$ emissions decreased with LOI increase and ESP temperature decrease. Testing demonstrated that maximum $\mathrm{Hg}$ reduction downstream of ESP was 40-45\% at ESP temperature higher than $300^{\circ} \mathrm{F}$ and $60-80 \%$ at ESP temperatures lower than $300^{\circ} \mathrm{F}$. The $80 \% \mathrm{Hg}$ control downstream of ESP was achieved for blend firing for LOI in the range of $10-11 \%$ and ESP temperature in the range of $270-285^{\circ} \mathrm{F}$.

Testing also demonstrated that incremental efficiency of $\mathrm{Hg}$ removal across the FGD system was in the range of $65-70 \%$. Most $\mathrm{Hg}$ at the stack was present in the elemental form. Mercury emissions at the stack were in the range of 1.8-3.0 lb/TBtu and 1.0-1.5 lb/TBtu for coal and blend firing, respectively.

Under optimized reburning conditions $\mathrm{NO}_{\mathrm{x}}$ emissions were reduced from $0.44 \mathrm{lb} / \mathrm{MBtu}$ to $0.13 \mathrm{lb} / \mathrm{MBtu}$, corresponding to about $70 \%$ reduction. 


\subsection{Introduction}

Regulations for controlling mercury $(\mathrm{Hg})$ emissions are currently being developed. In 2004, the EPA promulgated Maximum Achievable Control Technology (MACT) standards for coal-fired industrial boilers requiring $\mathrm{Hg}$ emissions from existing units to be lower than $9 \mathrm{lb} / \mathrm{TBtu}$. In December 2003, the EPA proposed two frameworks to regulate $\mathrm{Hg}$ emissions from coal-fired utility boilers. The first proposed framework is consistent with the present regulatory mechanism, requiring MACT standards to be used in formulating regulatory limits. The MACT approach would limit $\mathrm{Hg}$ emissions for bituminous coal to $2 \mathrm{lb} / \mathrm{TBtu}$ and require less aggressive reductions for low-rank coals. The second "cap-and-trade" framework would provide greater overall reduction in $\mathrm{Hg}$ emissions, requiring significant $\mathrm{Hg}$ reduction for all coal types. The deadline for adopting a final rule to regulate $\mathrm{Hg}$ from power plants was extended to March 15, 2005. Several other frameworks for Hg regulations also have been proposed. The Clear Skies Initiative proposed by President Bush mandates dramatic reductions in power plant $\mathrm{SO}_{2}, \mathrm{NO}_{\mathrm{x}}$, and $\mathrm{Hg}$ emissions over the next 15 years. The Clear Skies was proposed on February 14, 2002 and was first introduced to the Congress in 2002, but did not pass that year. The Clear Skies Act 2005 was re-introduced to The Senate Environment and Public Works committee on January 24, 2005. After reviewing the Act the committee will make decision about recommending the Act for the Senate consideration in 2005.

Many utilities are actively seeking efficient, cost-effective technologies for controlling multiple pollutants including $\mathrm{Hg}$ emitted from power plants. GE Energy has been developing an integrated multi-pollutant control approach for coal-fired power plants since the late $1990 \mathrm{~s}^{1,2,3}$. The approach enhances the "naturally occurring" $\mathrm{Hg}$ capture by fly ash through combustion optimization and increasing carbon in ash content and may include a polishing step that uses small amounts of activated carbon to further increase $\mathrm{Hg}$ removal efficiency. Another benefit of the approach includes reduced $\mathrm{NO}_{\mathrm{x}}$ emissions. Depending on coal type, unit configuration, and required level of $\mathrm{Hg}$ reduction, this approach may provide compliance with expected $\mathrm{Hg}$ regulations without activated carbon injection. If injection is required, the integrated approach requires less activated carbon than does the traditional approach, since optimized combustion staging improves Hg absorption on fly ash and increases the amount of oxidized mercury in flue gas. The approach can be tailored to specific unit configurations and coal types for optimal performance. 


\subsection{Project Description}

In this project General Electric Energy and Environmental Research Corporation (EER), a wholly owned subsidiary of GE Energy, conducted a preliminary field evaluation of the integrated approach for $\mathrm{Hg}$ control at Green Station Units 1 and 2 located near Henderson, Kentucky. Green Station is owned and operated by Western Kentucky Energy (WKE). Units 1 and 2 are equipped with cold-side electrostatic precipitators (ESPs) and wet scrubbers.

The integrated $\mathrm{Hg} / \mathrm{NO}_{\mathrm{x}}$ control method at Green Station utilizes coal reburning (injection of reburning coal and overfire air) and ESP optimization. In reburning technology, most of the coal (70-80\%) is burned in the primary combustion zone of the boiler, where $\mathrm{NO}_{\mathrm{x}}$ is typically generated. The remaining coal is injected downstream to provide a reburning zone with a fuel-rich environment where about $50-60 \%$ of the $\mathrm{NO}_{\mathrm{x}}$ from the primary combustion zone is reduced to $\mathrm{N}_{2}$. During the reburning process, carbon in the reburning coal does not burn out as completely as it would in a boiler environment with a high level of excess air. Thus, coal reburning usually increases the level of unburned carbon in the fly ash. This carbon is used to control $\mathrm{Hg}$ emissions. Most of the coal Hg content is transferred to the gas phase in the primary combustion zone of the boiler. Mercury in flue gas is absorbed by carbon present in the fly ash in the ESP. This fly ash can be landfilled or optionally treated in an ash burnout unit to recover heat and generate salable fly ash. A carbon bed can be used to absorb Hg released from fly ash in the burnout unit. Mercury absorption in the carbon bed can be done more economically than in the boiler. Since fly ash generated at Green Station is landfilled, Hg recovery in an ash treatment system could not be investigated in this project.

The program comprised field and pilot-scale tests and engineering studies and consisted of the following five tasks:

1. Baseline field measurements

2. Pilot-scale testing

3. Systems design

4. Preliminary field evaluation

5. Data reduction, management and reporting.

Task \#1 provided baseline data on Hg emissions before reburning system retrofit. Data collected in Task \#1 were also used to compare with pilot-scale data obtained in Task $\# 2$ to 
evaluate scalability of pilot-scale data. Pilot-scale facility in Task \#2 was configured to match time-temperature profile found in Green Unit 2. The same fuels fired at full-scale were tested in pilot-scale. Baseline data on $\mathrm{Hg}$ emissions and pilot-scale results were evaluated in Task \#3 to determine optimum conditions for $\mathrm{Hg}$ removal in Units 1 and 2 when the reburning system became operational. Armed with the pilot scale information, a field optimization program in Unit 2 was structured in Task \#4 to achieve the conditions identified in the pilot-scale tests using the advanced combustion systems. The goal of these tests was to identify stable conditions that yield high $\mathrm{Hg}$ capture, low $\mathrm{NO}_{\mathrm{x}}$ emissions, low byproducts $(\mathrm{CO}, \mathrm{LOI})$ and were acceptable operating conditions for WKE operators.

The following sections present a description of Green Units 1 and 2 and describe in detail project activities.

\subsection{Description of Green Units 1 \& 2}

Western Kentucky Energy's Green Station Units 1 and 2 are nearly identical opposed-wallfired steam generators manufactured by Babcock and Wilcox. Each unit was originally designed to produce $1,840,000 \mathrm{lb} / \mathrm{hr}$ of main steam. At its maximum continuous rating (MCR) each unit has a peak generating capacity of $255 \mathrm{MWe}$ (gross). Excess oxygen is typically 3.0 to 3.5 percent at the economizer exit. As boiler load drops, boiler excess $\mathrm{O}_{2}$ is increased to maintain reheat steam temperature.

EER retrofitted Units 2 and 1 with reburning systems in 2002 and 2003, respectively. The overfire air system consists of 10 ports located at Elevation $165 \mathrm{~m}$ (Figure 1). Five ports are located on the front wall and five ports are located on the rear wall. Heated combustion air is supplied from the secondary air ducts on the hot side of the air heater. The overfire air ports are EER's double concentric design that features an inner and outer nozzle. In most operating modes, the inner nozzle supplies between $12 \%$ and $15 \%$ of the total air. The remaining air is supplied through the outer nozzle. The air fraction to either nozzle can be controlled automatically from the control room. 


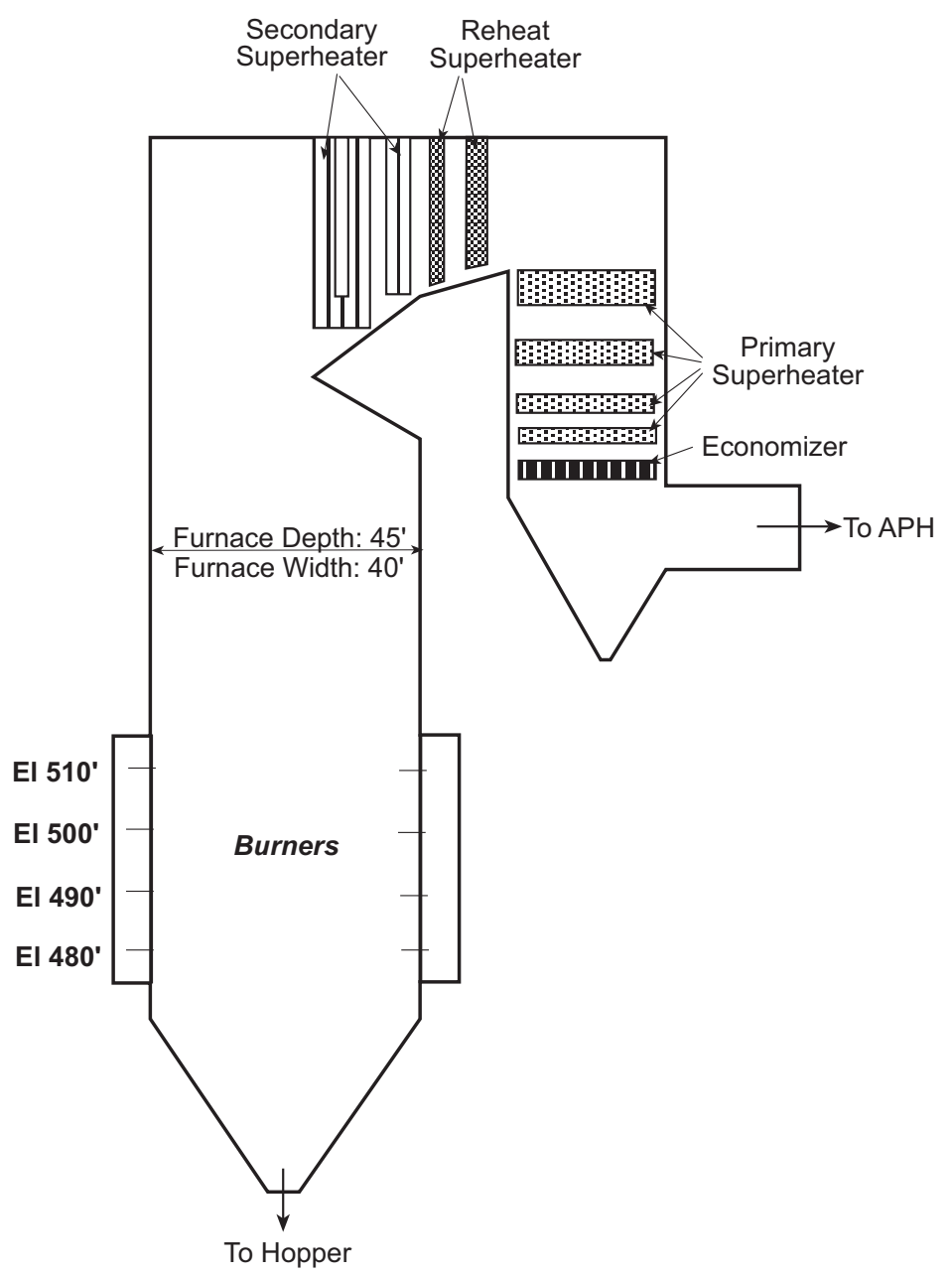

Figure 1. Side elevation of Green Unit 2.

The coal reburning system is comprised of PC piping modifications, furnace penetrations, and controls along with 12 reburning fuel injectors located at Elevation $520 \mathrm{ft} 6$ inches. Six injectors are located on the front wall and six injectors are located on the rear wall. The system was designed with a capacity to supply between 20 and 30 percent of the heat input as reburning fuel. To accommodate the reburning system, the top row of burners are taken out of service. The installation also included coal line balancing dampers and combustion sensors. The dampers and sensors were used in combustion optimization activities. A schematic of the reburning system on Unit 2 is presented in Figure 2.

WKE usually operates the reburning system only during ozone season (May - September). The OFA portion of the system is part of the normal unit operation during the rest of the year. 


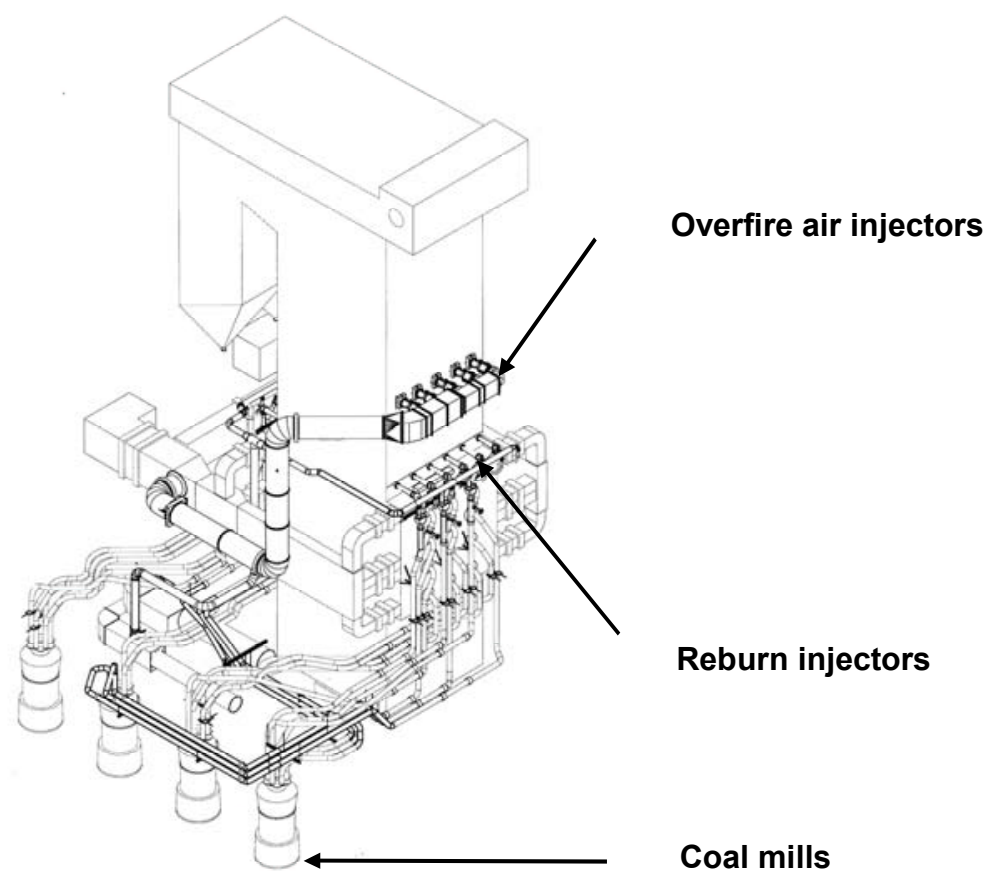

Figure 2. Reburning system on Green Unit 2.

Green Station Units 1 and 2 typically fire two types of fuel: a bituminous coal and a blend of bituminous coals based on availability. Prior to reburning retrofit, loss-on-ignition (LOI) for the fly ash was less than 2 percent when firing bituminous coal.

WKE considers information on fuel properties to be of proprietary nature. Properties of fuels tested in this project are presented in Appendix $I$ and should be treated as confidential information. 


\subsection{Pilot-Scale Testing}

The first activity in optimizing $\mathrm{Hg}$ reduction in Units 1 and 2 was to test fuels fired at Green Station in pilot-scale. Previous experience with $\mathrm{Hg}$ and $\mathrm{NO}_{\mathrm{x}}$ studies suggested that pilotscale testing produced the same trends in the effect of process conditions on $\mathrm{Hg}$ and $\mathrm{NO}_{\mathrm{x}}$ reduction as in full-scale. Results of pilot-scale testing would be then used to determine optimum conditions for $\mathrm{Hg}$ and $\mathrm{NO}_{\mathrm{x}}$ reduction at Green Station.

Pilot-scale testing was conducted in Boiler Simulator Facility (BSF) to determine effects of process conditions and fuel composition on $\mathrm{Hg}$ removal. Testing focused on determining effects of the following factors on $\mathrm{Hg}$ removal 1) fuel composition, 2) carbon in ash content (also characterized as Loss On Ignition, or LOI), and 3) ESP temperature. The following sections give BSF description and present results of pilot-scale testing.

\subsection{Boiler Simulator Facility}

The BSF (Figure 3) is a down-fired combustion research facility with a nominal firing rate of $300 \mathrm{~kW}(1 \mathrm{MMBtu} / \mathrm{hr})$. It is designed to simulate the thermal characteristics of a utility boiler. As shown in Figure 3, the BSF consists of a burner, vertical radiant furnace, and horizontal convective pass. The facility's variable swirl diffusion burner is equipped to fire coal, oil, or natural gas. The furnace is constructed of eight modular refractory lined spool sections with access ports. The furnace has an inside diameter of $0.55 \mathrm{~m}$ and a height of $5.4 \mathrm{~m}$. The radiant section is equipped with adjustable heat removal panels. Configuration of these panels is adjusted such that the BSF matches the residence time-temperature profile and furnace exit gas temperature of a specific full-scale boiler. The convective pass is equipped with air-cooled tube bundles designed to simulate the superheater and economizer sections of a coal-fired boiler.

Temperature gradient in BSF was adjusted to simulate thermal environment in Units 1 and 2. Figure 4 compares axial temperature profile in the BSF and Unit 2. Unit 2 temperature profile was calculated using EER's thermal model that was successfully used in the past to predict temperature environment in coal-fired boilers. Figure 4 shows good agreement between full- and pilot-scale temperature profiles at temperatures below $1200 \mathrm{~K}$ at which $\mathrm{Hg}$ oxidation and adsorption on fly ash is expected to take place. 


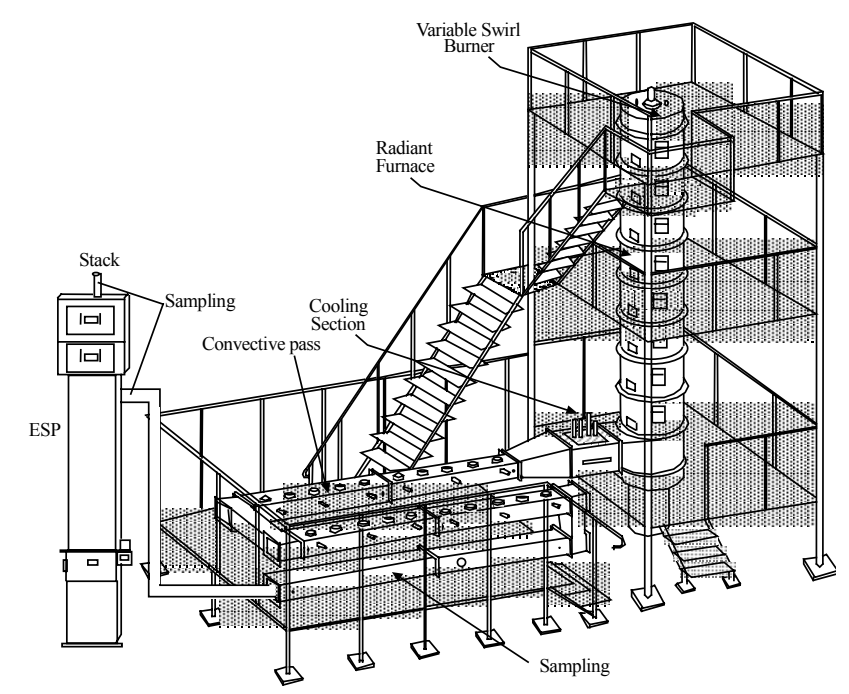

Figure 3. Boiler Simulator Facility (BSF).

The ESP for the BSF is a single-field down-flow cylindrical unit with an axial corona electrode.

Process performance was characterized by continuous emissions monitors (CEMs), which provided an online analysis of flue gas composition. The CEMs consisted of a water-cooled sample probe, sample conditioning system (to remove water and particulate), and gas analyzers. Species analyzed, detection principles, and detection limits were as follows:

- $\mathrm{O}_{2}$ : paramagnetism, $0.1 \%$

- $\quad \mathrm{NO}_{\mathrm{x}}$ : chemiluminescence, $1 \mathrm{ppm}$

- $\quad$ CO: nondispersive infrared, $1 \mathrm{ppm}$

- $\quad \mathrm{CO}_{2}$ : nondispersive infrared, $0.1 \%$

High purity dry nitrogen was used to zero the analyzers. Certified span gases were used to calibrate and check linearity of the analyzers. A chart recorder was used to obtain a hard copy of analyzer outputs. A personal computer based data acquisition system (LabTech Notebook) was used for storage and analysis of test data. 


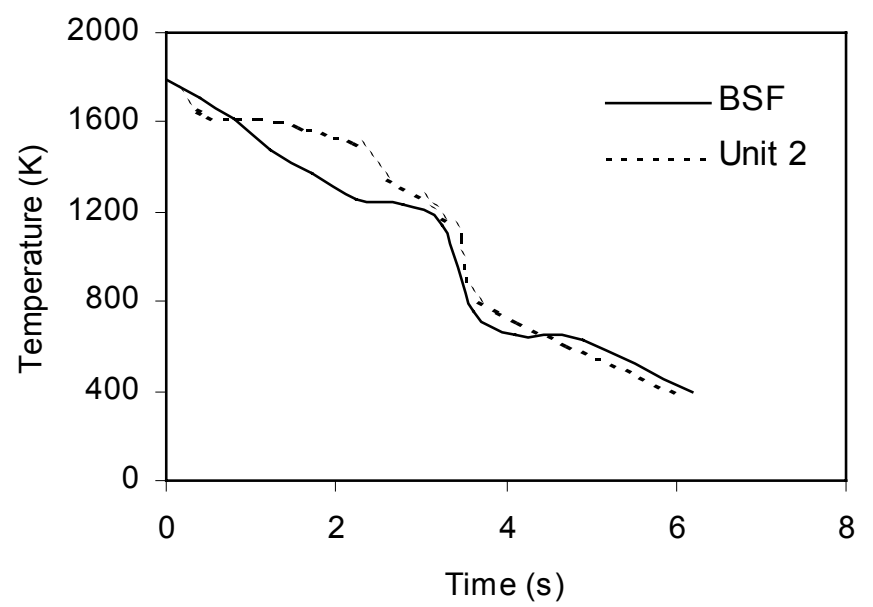

Figure 4. Axial temperature profiles in BSF and WKE Green Unit 2.

\subsection{Results of Pilot-Scale Testing}

Combustion tests were performed to evaluate effects of process conditions and fuel type on $\mathrm{Hg}$ emissions. Characteristics of tested fuels are shown in Attachment I Table I-1. At the time of the testing WKE was purchasing coals from two suppliers. Two coals and one coal blend were tested in pilot-scale. Two tested coals were bituminous coals with high sulfur content. Coals had similar compositions except for higher $\mathrm{Cl}$ content in coal 2. Concentrations of total $\mathrm{Hg}$ and elemental $\mathrm{Hg}\left(\mathrm{Hg}^{0}\right)$ were measured at ESP outlet using $\mathrm{Hg}$ analyzer Sir Galahad from PS Analytical. Concentration of oxidized $\mathrm{Hg}\left(\mathrm{Hg}^{+2}\right)$ was determined as a difference between $\mathrm{Hg}$ and $\mathrm{Hg}^{0}$.

High carbon fly ash was formed using two approaches: air staging and coal reburning. In air staging, part of the combustion air (usually $15-30 \%$ of total) is redirected from the main combustion zone into an overfire (OFA) zone. In reburning, part of the fuel (usually 10-30\% of total) is injected downstream of the main combustion zone (reburning zone); overfire air is injected downstream of the reburning zone to complete fuel combustion. In both approaches fuel combustion occurs in a more fuel-rich environment than at typical combustion conditions, usually resulting in incomplete fuel combustion and increased carbon in ash content. However, in reburning combustion of secondary (reburning) fuel takes place at lower temperatures than in air staging, which potentially can affect properties of fly ash and its reactivity towards $\mathrm{Hg}$.

Process variables in tests included location of OFA injection, amount of OFA, amount of 
reburning fuel, and ESP temperature. The ESP temperature was adjusted by changing facility load.

Figure 5 shows $\mathrm{Hg}$ removal and $\mathrm{Hg}$ emissions for three tested fuels as a function of LOI at air staging conditions. Figure 5a demonstrates that at air staging conditions efficiency of $\mathrm{Hg}$ removal increases as LOI increases from $0 \%$ to $5-6 \%$, but then stays about the same as LOI further increases to $16 \%$. Mercury removal efficiencies for all three tested fuels were similar at the same LOI. It should be noted, however, that because of different reactivity of fuels the same combustion conditions generated fly ash with different LOI. Thus, although the air staging data presented in Figure 5a can be used to establish target LOI required to achieve desired $\mathrm{Hg}$ removal efficiency, combustion conditions that produce target LOI are affected by fuel properties. Maximum achieved $\mathrm{Hg}$ reduction in air staging tests was $60 \%$. The ESP temperature in air staging tests was $350^{\circ} \mathrm{F}(450 \mathrm{~K})$. Due to the lower $\mathrm{Hg}$ content in the blend, $\mathrm{Hg}$ emissions for blend firing were lower than for coal firing at the same LOI (Figure 5b).

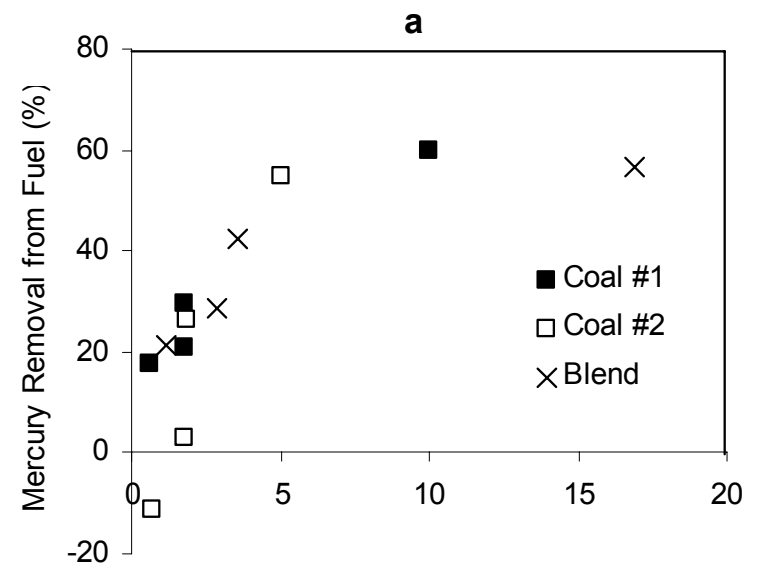

LOI $(\%)$

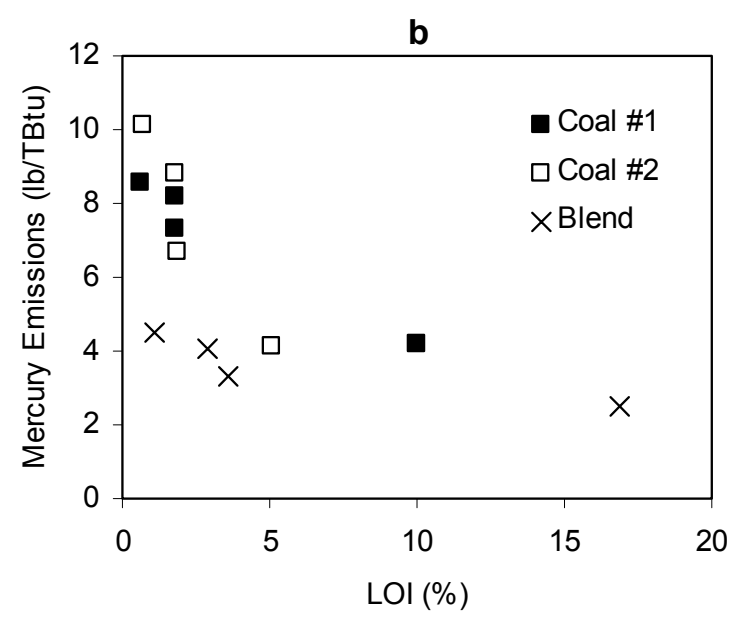

Figure 5. Mercury removal (a) and $\mathrm{Hg}$ emissions (b) as a function of LOI at air staging.

Effects of reburning and ESP temperature on $\mathrm{Hg}$ removal were evaluated for coal 1 and blend firing. Figure 6 shows $\mathrm{Hg}$ removal efficiency and $\mathrm{Hg}$ emissions as a function of LOI at ESP temperatures in the range of $310-360^{\circ} \mathrm{F}(427-455 \mathrm{~K})$. 

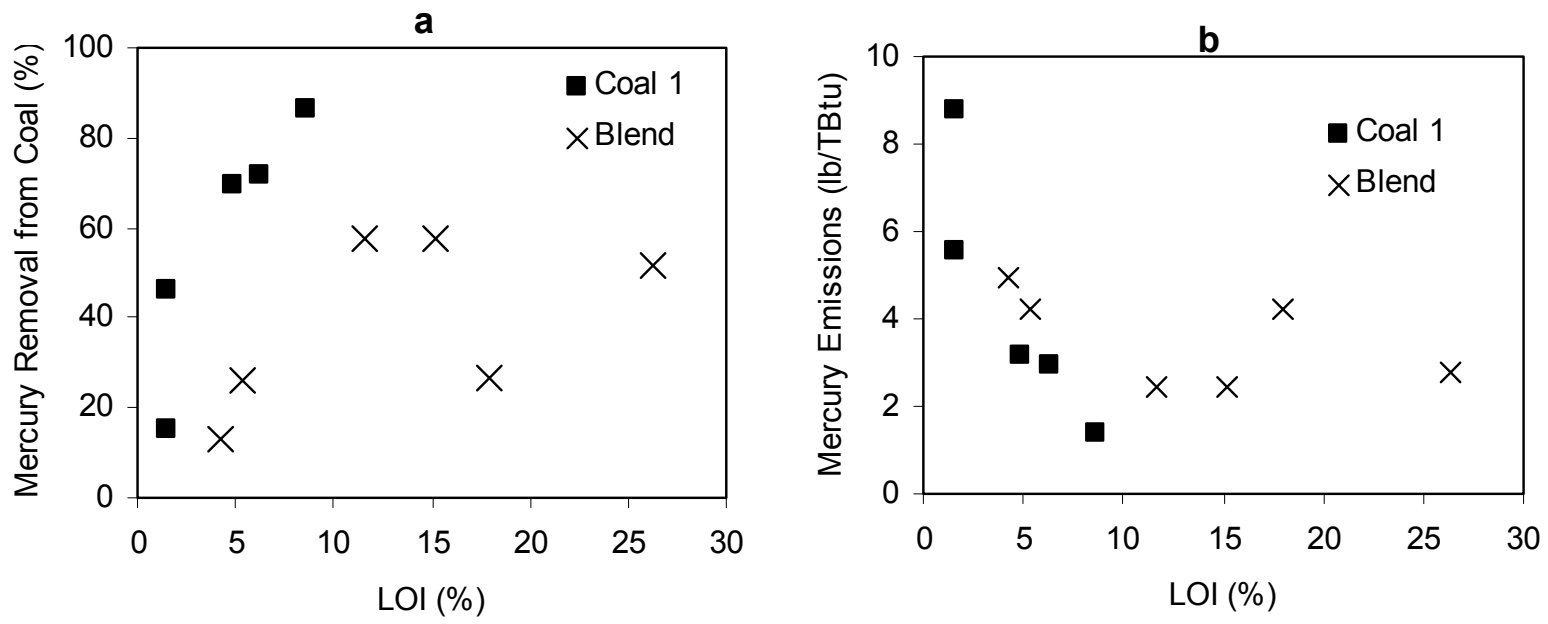

Figure 6. Mercury removal (a) and $\mathrm{Hg}$ emissions (b) as a function of LOI at reburning conditions at ESP temperatures of $310-360^{\circ} \mathrm{F}$.

Figure 6a demonstrates that $\mathrm{Hg}$ removal efficiencies for coal are higher than those for blend firing at the same LOI. Maximum LOI generated in reburning tests with blend was $\sim 26 \%$ while for coal it was $\sim 9 \%$. This is result of higher reactivity of coal 1 due to its higher volatiles content (Table I-1). The maximum Hg removal efficiency achieved for coal firing was close to $90 \%$ while for blend firing it was $60 \%$. This suggests that in reburning, fuel properties have a significant effect on fly ash reactivity towards $\mathrm{Hg}$. At the same time, $\mathrm{Hg}$ emissions for coal and blend firing were similar (Figure 6b).

Figure 7 shows efficiency of $\mathrm{Hg}$ removal for coal 1 at reburning conditions at different ESP temperatures. For comparison, data on the effect of LOI and ESP temperature on Hg removal obtained by $\mathrm{Consol}^{4}$ are also shown. In that project fly ashes obtained from Illinois utility and industrial boilers were injected into 1.5 MM Btu/hr combustor duct and collected in ESP. Mercury removals were measured across the duct and ESP. The flue gas temperature was controlled using both humidification with an in-duct atomization nozzle and the pilot plant heat exchanger. The CONSOL data showed that Hg absorption on fly ash was affected by LOI and improved as ESP temperature decreased. Since data on coal composition in the Consol study ${ }^{4}$ were not available, Figures 7 and 8 do not show data on $\mathrm{Hg}$ emissions.

Figure 7 demonstrates that ESP temperature has an effect on $\mathrm{Hg}$ removal: $\mathrm{Hg}$ removal at $250-270^{\circ} \mathrm{F}(394-405 \mathrm{~K})$ at LOI $\sim 5 \%$ was $\sim 80 \%$ while at $440-490^{\circ} \mathrm{F}(500-505 \mathrm{~K})$ it was only $\sim 20 \%$. This suggests that lowering ESP temperature can be an effective approach to increasing $\mathrm{Hg}$ 
adsorption on fly ash.

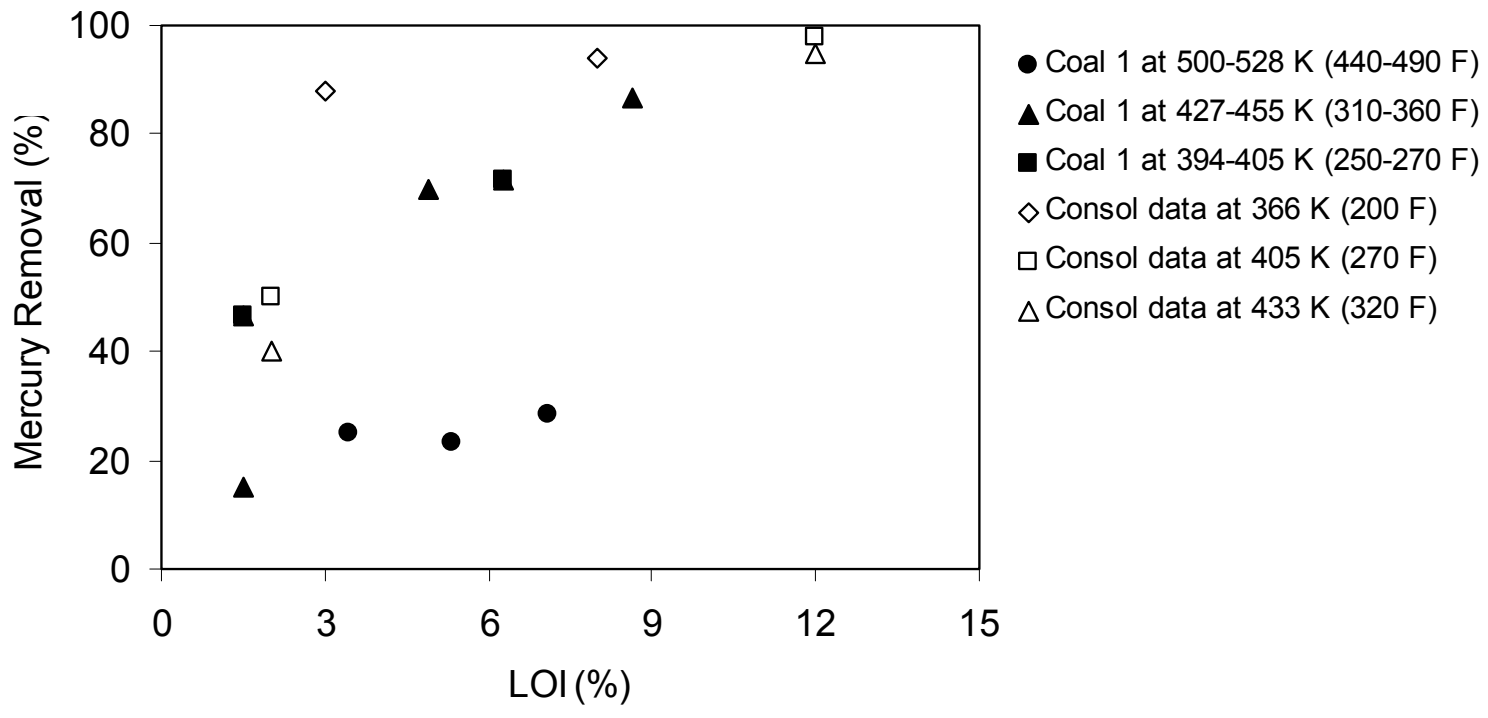

Figure 7. Mercury removal for coal 1 at reburning conditions at different ESP temperatures as a function of LOI. Data obtained by Consol on re-injection of high carbon fly ash are also shown.

Data on effects of LOI and ESP temperatures were used to develop an empirical correlation between $\mathrm{Hg}$ removal, LOI, and ESP temperature. Figure 8 shows a comparison between experimental data and correlation predictions. Figure 8 demonstrates good agreement between calculated and experimental data for wide ranges of LOIs and temperatures.

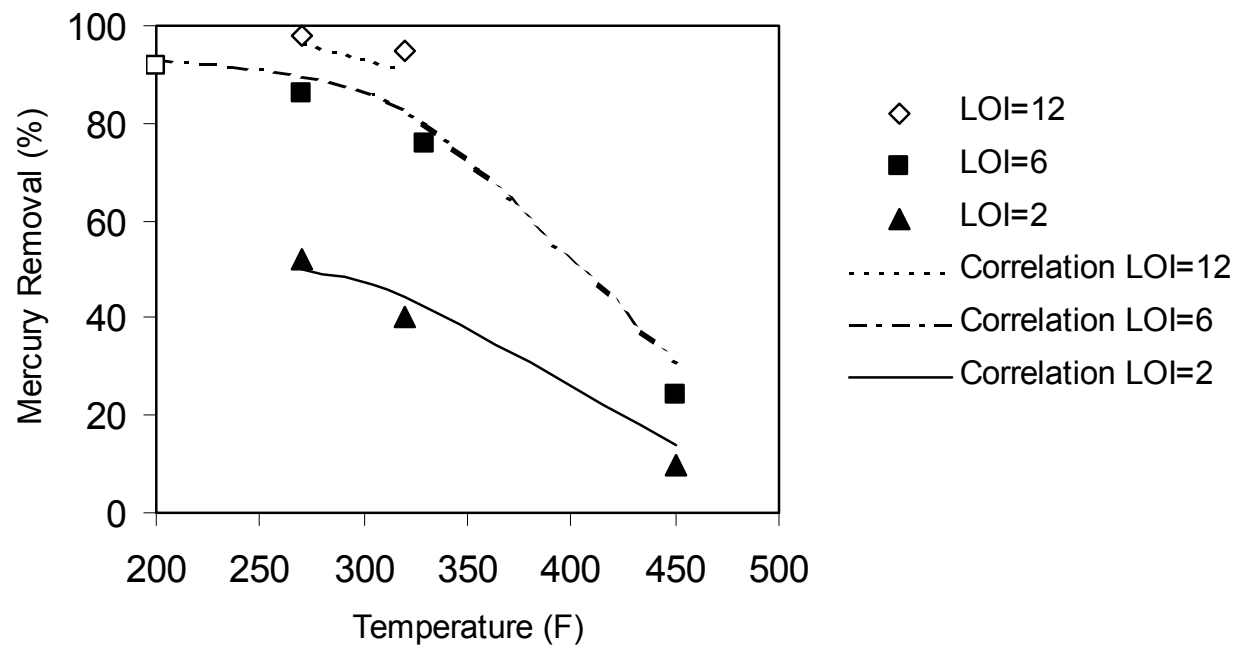

Figure 8. Effect of ESP temperature on $\mathrm{Hg}$ removal. Filled symbols represent present data, open symbols Consol data, lines correlation predictions. 
Figure 9 shows experimental data on $\mathrm{Hg}$ removal obtained in BSF (presented in Figure 7) at ESP temperatures of $250-450^{\circ} \mathrm{F}(390-500 \mathrm{~K})$ and adjusted using empirical correlation to the temperature of $350^{\circ} \mathrm{F}(450 \mathrm{~K})$. Figure 9 shows good agreement between experimental data and correlation predictions. It also shows that uncertainty of experimental data is about $\pm 10 \%$.
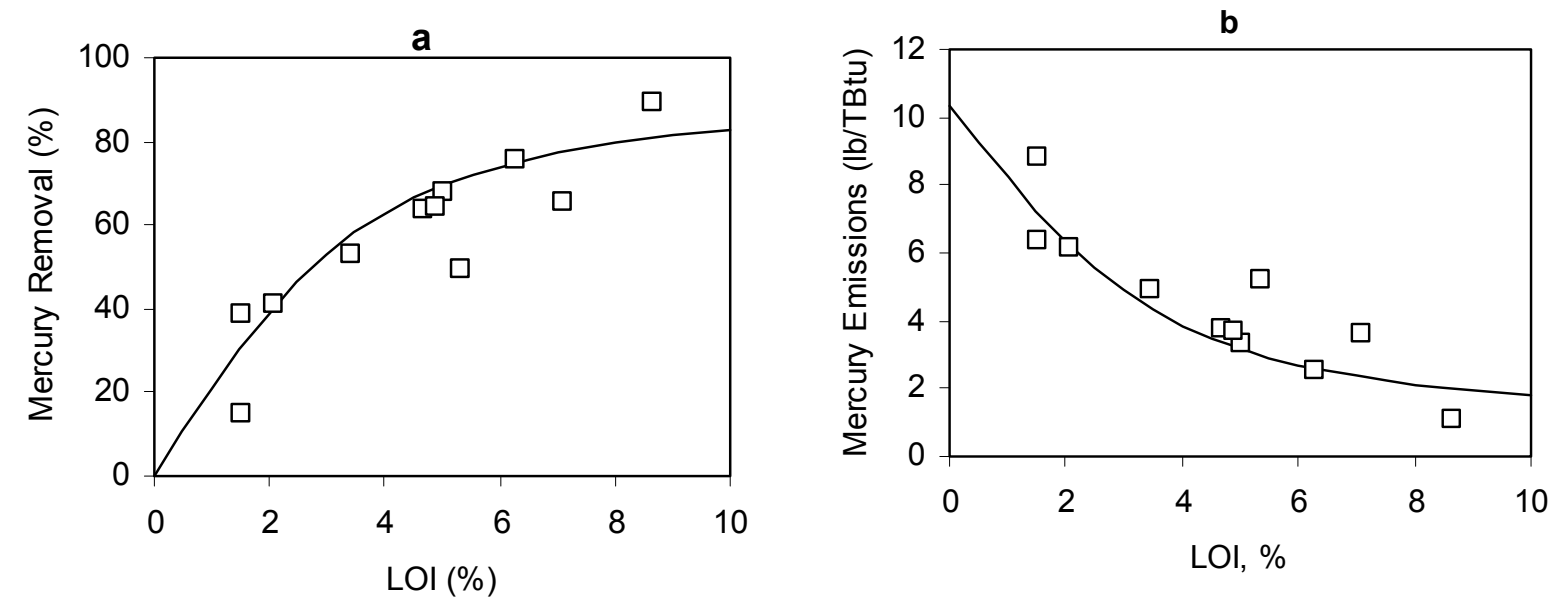

Figure 9. Mercury removal (a) and $\mathrm{Hg}$ emissions (b) in reburning as a function of LOI. ESP temperature is $350^{\circ} \mathrm{F}(450 \mathrm{~K})$.

Figure 10 shows the predicted by the transfer function effect of the temperature and LOI on Hg absorption by fly ash.

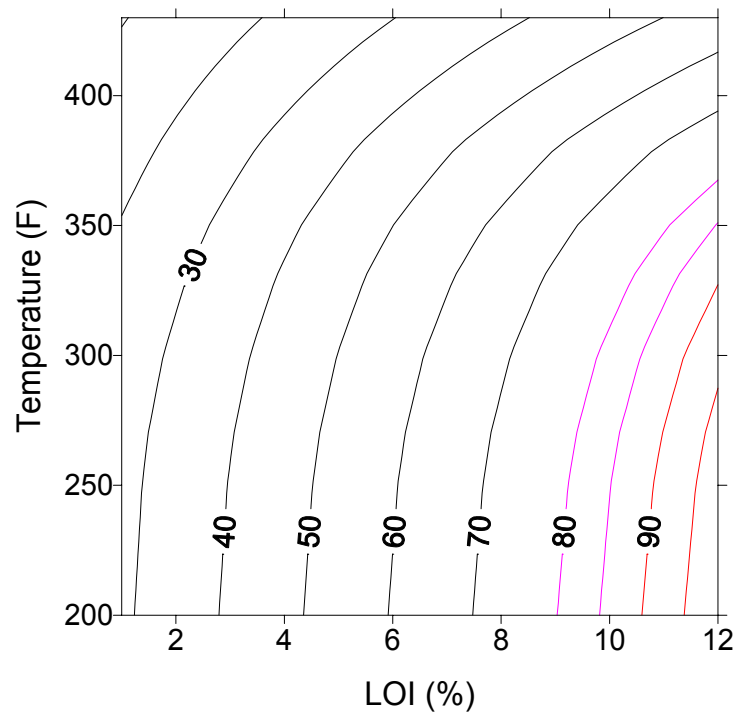

Figure 10. Predicted effect of temperature and LOI on $\mathrm{Hg}$ removal (solid lines). Numbers indicate level of mercury removal.

Figure 10 suggests that both temperature and LOI should be considered in selecting optimum conditions for $\mathrm{Hg}$ removal. LOI change in the range of $2-8 \%$ offers the most significant 
effect on $\mathrm{Hg}$ removal. LOI increase from $8 \%$ to $12 \%$ provides only marginal efficiency improvement in $\mathrm{Hg}$ reduction. Temperature decrease below the acid dew point can result in sulfuric acid condensation and duct corrosion. While the acid dew point depends on a number of parameters including coal sulfur content, in most cases for bituminous coals it is lower that $290^{\circ} \mathrm{F}$. Figure 10 suggests that high $\mathrm{Hg}$ removal efficiency is difficult to achieve at temperatures higher than $350^{\circ} \mathrm{F}$ and that $80-90 \% \mathrm{Hg}$ removal can be potentially achieved at ESP temperatures of 290$350^{\circ} \mathrm{F}$.

Pilot-scale testing suggested that fuel composition affected efficiency of $\mathrm{Hg}$ reduction: efficiency of $\mathrm{Hg}$ removal at the same LOI was higher for coal firing than for blend firing. However, due to the lower Hg content in the blend, Hg emissions for two fuels were similar. Testing also demonstrated that Hg removal improved with LOI increase and ESP temperature decrease. Based on results of pilot-scale testing it is estimated that $80 \% \mathrm{Hg}$ control at Green Station at ESP outlet could be achieved at LOI $\geq 8 \%$ and ESP temperatures $\leq 300^{\circ} \mathrm{F}(420 \mathrm{~K})$. 


\subsection{Testing of Baseline Mercury Emissions}

Mercury testing at Green Station consisted of four programs. The first program was conducted in September 2003 with the goal to obtain data on baseline Hg emissions in Unit 2. The second and third programs were conducted in January and April 2004, respectively, and were designed to obtain data on $\mathrm{Hg}$ emissions while reburning systems in Units 1 and 2 were optimized for $\mathrm{NO}_{\mathrm{x}}$ reduction. The fourth program involved final reburning system optimization for $\mathrm{Hg}$ and $\mathrm{NO}_{\mathrm{x}}$ control in Unit 2 in September 2004. The following sections give a description of the baseline test program.

\subsection{Program Description}

The test program consisted of 5 tests with the boiler operating under nominal full load conditions. Reburning and OFA systems during baseline testing were not operational. However, minimal air flow through OFA ports was maintained to cool the ports. The total cooling air accounted for $11-12 \%$ of the total combustion air. Thus, baseline tests corresponded to Unit 2 operating at slightly air staged conditions.

Table 1 shows a matrix of the baseline test program. The boiler was configured in the normal firing configuration, that is, with the upper row of burners in service and cooling air flowing through the overfire air injectors. Tests 1, 2, and 3 were conducted with the boiler firing the coal blend (see Attachment I Table I-2 for details on fuel composition). Tests 4 and 5 were conducted with the boiler firing a single coal. For Test 5 , OFA was increased to $22 \%$ to measure the impact of a moderate staging on $\mathrm{Hg}$ emissions.

Table 1. Test matrix for baseline testing.

\begin{tabular}{|c|c|c|c|c|c|c|}
\hline & \multirow{2}{*}{ Day } & \multirow{2}{*}{$\begin{array}{c}\text { Test } \\
\text { No }\end{array}$} & Fuel & \multirow{2}{*}{ OFA } & \multicolumn{3}{|c|}{ Ontario Hydro Sampling } \\
\cline { 1 - 4 } & & & ESP Inlet & $\begin{array}{c}\text { ESP } \\
\text { Outlet }\end{array}$ & Stack \\
\hline 30-Sep & 1 & Blend & $11 \%$ & $X$ & $X$ & \\
\hline 1-Oct & 2 & Blend & $11 \%$ & $X$ & & $X$ \\
\hline 1-Oct & 3 & Blend & $11 \%$ & & $X$ & $X$ \\
\hline 2-Oct & 4 & Coal & $11 \%$ & & $X$ & $X$ \\
\hline 2-Oct & 5 & Coal & $22 \%$ & & $X$ & $X$ \\
\hline
\end{tabular}


Relative Hg measurement locations are shown in Figure 11. Manual Hg sampling using the Ontario Hydro Method was performed at three locations: the ESP inlet, the ESP outlet, and the stack. Fuel samples were collected from the silos and fly ash was collected from the economizer exit duct during each test. EER also performed $\mathrm{O}_{2}$ profiling at the ESP inlet because of the possibility of $\mathrm{O}_{2}$ stratification as the flow makes a ninety-degree turn into the ESP. To closely monitor boiler operations, EER also measured $\mathrm{O}_{2}$ on a dry basis continuously during each test at the economizer exit duct. All measurements were made on the boiler's East side duct.

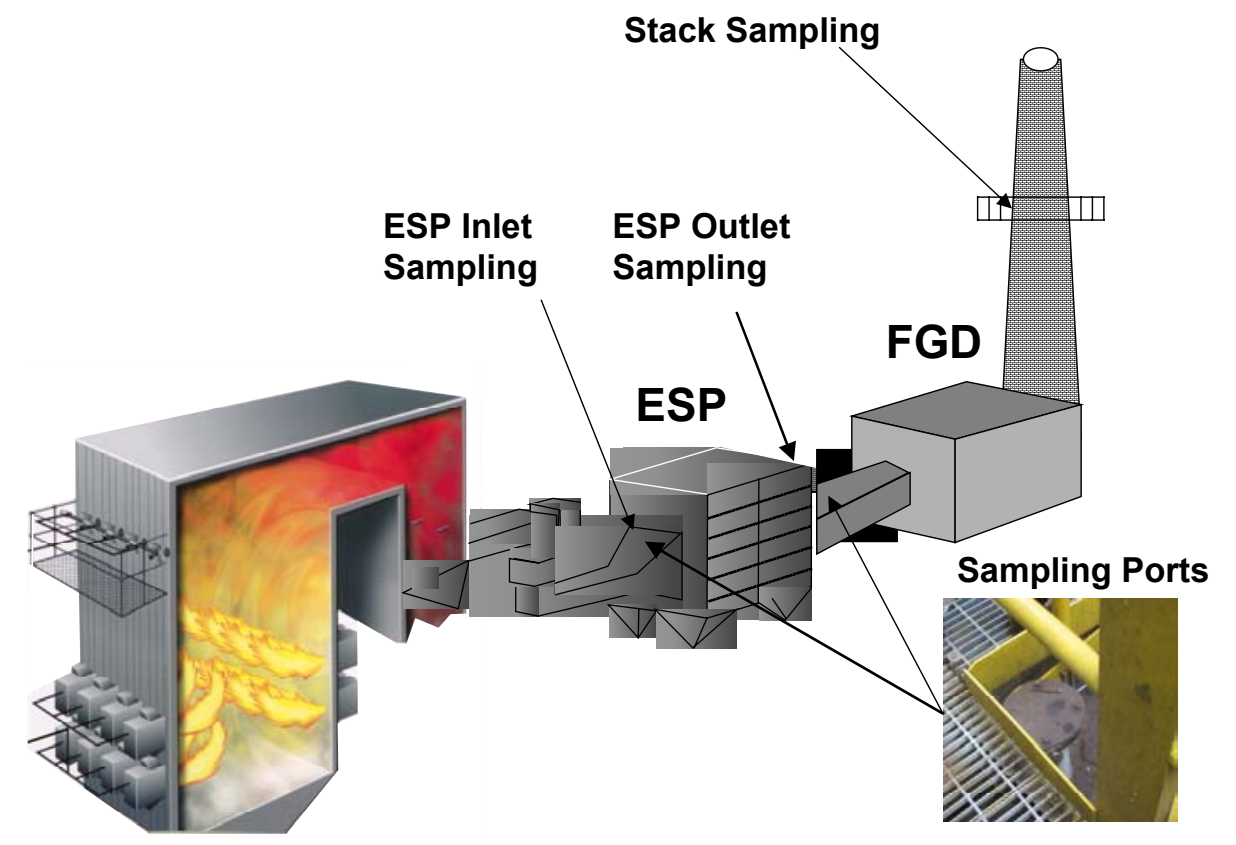

Figure 11. Mercury sampling locations.

\subsection{Data Collection and Sampling Procedures}

Pertinent data from plant operations were collected to document the operating conditions of the boiler as part of the $\mathrm{Hg}$ test program. This section of the report summaries the sampling procedures that were used in the test program, and the data collection protocols that were followed. The following is a summary of the data collected.

- Boiler operating data from the plant information system

- $\mathrm{NO}_{\mathrm{x}}, \mathrm{CO}_{2}$ and $\mathrm{SO}_{2}$ from the plant CEMS at the stack

- Plant $\mathrm{O}_{2}$ from plant sensors at the economizer outlet

- $\mathrm{O}_{2}$ from 12 point sampling grid at the East economizer outlet

- $\mathrm{O}_{2}$ stratification checks at the East ESP Inlet

- Hg concentrations by Ontario Hydro Method 
- Coal samples

- Fly ash samples.

The following sections present a summary of the boiler operating data, $\mathrm{O}_{2}$ measurements, coal and fly ash sampling, and $\mathrm{Hg}$ emissions.

\subsubsection{Boiler Operating Data}

Boiler operating data were downloaded from the plant's digital information network at the end of each test day. The data points included measured steam, fuel, flue gas, and combustion air flows and properties, power output, CEMS data, and plant $\mathrm{O}_{2}$ data. Each point was logged by the plant information system at one-minute intervals and averaged across the exact sampling period for each test. A summary of the operating data is included in Attachment I Table I-3.

To characterize the operating conditions of the boiler, the data were used to calculate boiler efficiency and the actual fuel and air flows. Boiler efficiency was calculated using the ASME PTC 4.1 Heat Loss Efficiency Method. For these calculations, fuel analysis was provided from the actual samples taken during the tests (Table I-2), and the carbon loss was measured from the actual fly ash samples collected during the tests. A heat balance was then used to calculate the actual fuel flow and the plant $\mathrm{O}_{2}$ measurements were used to calculate the actual airflow. Stoichiometric values for the burner zone and for the OFA zone as well as the percent OFA are included in the Attachment I Table I-3.

\subsubsection{Continuous $\mathrm{O}_{2}$ Monitoring $/ \mathrm{O}_{2}$ Profiling}

A 12-point sampling grid was installed in the East duct of the economizer exit duct to monitor $\mathrm{O}_{2}$ concentrations during the tests. Sintered metal filters were installed on the end of each probe to remove ash particles from the flue gas. The gas extracted from each point was metered to ensure uniform sampling. A moisture knockout device was used to remove moisture from the flue gas sample. The dry flue gas sample was then pumped to the mobile CEMS laboratory for analysis of $\mathrm{O}_{2}$ concentration. The analyzer was calibrated using an EPA Protocol 1 calibration gas before and after each test. A bias check was performed prior to test number 1 to insure the integrity of the sampling line and leak checks were conducted on a daily basis.

Figure 12 shows oxygen profile across East side duct. Oxygen traversing was done on four occasions: prior to the beginning of the test program and on first three test days. Traversing was 
done across distance of $180 \mathrm{~cm}$ which comprises half the duct height. Figure 12 demonstrates that relatively small $\mathrm{O}_{2}$ bias (about 10\%) exists across the flow, indicating that flow is well mixed. This suggests that $\mathrm{Hg}$ bias at the location of $\mathrm{Hg}$ measurements at ESP inlet is also small. Due to the intense flue gas mixing in ESP and wet scrubber, it is expected that $\mathrm{Hg}$ bias at the location of $\mathrm{Hg}$ measurements at ESP outlet and stack to be even smaller. Velocity traverses made at these three locations during Ontario Hydro sampling confirmed the flow uniformity (see Section 3.2.5).

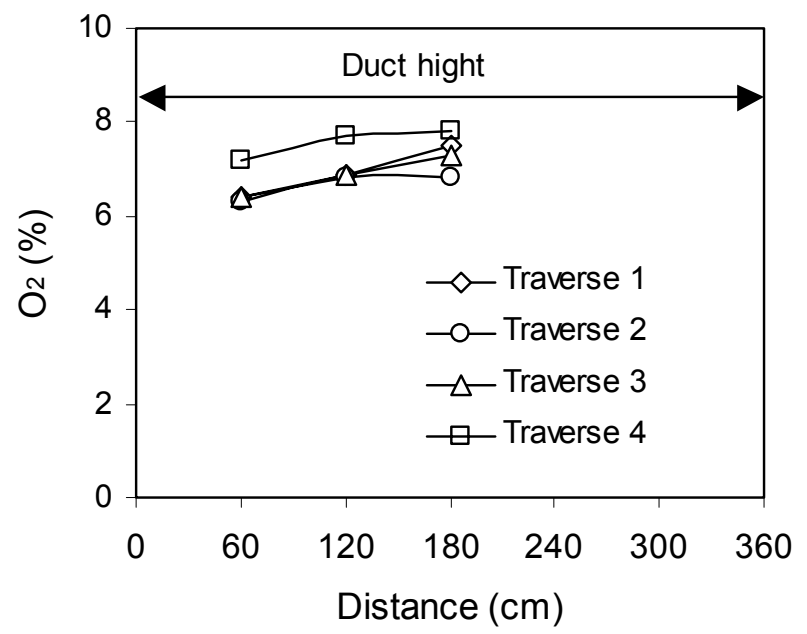

Figure 12. Oxygen profile across East side duct.

\subsubsection{Coal Sampling}

Coal samples were taken during the second half of each test period. To achieve the most representative sample, coal was acquired from the bottom of the four coal silos. A composite sample was then assembled by combining an equal mass from each of the individual silo samples. The samples were labeled to include the test number, sampling time, and sampling location and sent to an independent laboratory for determinations of ultimate, proximate, and heating value as well as Hg concentration. Table I-2 in Attachment I shows composition of tested fuels.

\subsubsection{Fly Ash Samples}

Fly ash samples were collected in-situ from the East side economizer exit duct. The fly ash sampling system consisted of a multi hole probe that ran the width of the economizer exit duct, a high volume sampler that was used to pull flue gas, and a cyclone to capture the ash into a plastic jar. At the completion of each test, the samples were placed in an airtight container, labeled, and 
shipped to a laboratory for analysis. The ash samples were analyzed for LOI using a Hot Foil ${ }^{\mathrm{TM}}$ LOI Analyzer. The LOI data for tests 1-5 are shown in Attachment I Table I-3.

\subsubsection{Mercury Emissions}

Mercury emissions were measured by Metco Environmental using the Ontario Hydro Method, Revised July 7, 1999. Two tests were conducted at ESP inlet, four at ESP outlet, and four at the stack. A preliminary velocity traverses were made at each location in order to determine the uniformity and magnitude of the flow prior to testing. Several traverse points at each location were checked for cyclone flow and none was found to be present. Three traverse points were sampled at each of the ESP locations and twelve points were sampled at the stack. For each run at the ESP inlet and outlet, samples of flue gas of 50 min duration were taken isokinetically at each of the traverse points for a total sampling time of $150 \mathrm{~min}$. At the stack samples of 10 min duration were taken isokinetically at each of the twelve traverse points for a total sampling time of $120 \mathrm{~min}$. Tables 2, 3, and 4 show results of Ontario Hydro measurements.

Table 2. Summary of baseline tests for ESP inlet duct.

\begin{tabular}{|c|c|c|}
\hline Test Number & 1 & 2 \\
\hline Duct Flow Rate (acfm) & 357,272 & 384,070 \\
\hline$\% \mathrm{O}_{2}(\% \mathrm{Vol})$ & 4.6 & 4.4 \\
\hline Duct Temperature $(\mathrm{F})$ & 310 & 313 \\
\hline Particle Bound Mercury Emissions $\left(\mu \mathrm{g} / \mathrm{m}^{3}\right)$ & 0.19 & 0.079 \\
\hline Elemental Mercury Emissions $\left(\mu \mathrm{g} / \mathrm{m}^{3}\right)$ & 0.607 & 0.735 \\
\hline Oxidized Mercury Emissions $\left(\mu \mathrm{g} / \mathrm{m}^{3}\right)$ & 7.122 & 7.127 \\
\hline Total Mercury Emissions $\left(\mu \mathrm{g} / \mathrm{m}^{3}\right)$ & 7.919 & 7.941 \\
\hline
\end{tabular}

Table 3. Summary of results for ESP outlet duct.

\begin{tabular}{|c|c|c|c|c|}
\hline Test Number & 1 & 3 & 4 & 5 \\
\hline Duct Flow Rate (acfm) & 260,175 & 271,313 & 264,213 & 280,834 \\
\hline$\% \mathrm{O}_{2}(\% \mathrm{Vol})$ & 4.6 & 4.6 & 4.6 & 4.2 \\
\hline Duct Temperature $(\mathrm{F})$ & 316 & 316 & 294 & 299 \\
\hline Particle Bound Mercury Emissions $\left(\mu \mathrm{g} / \mathrm{m}^{3}\right)$ & 0.016 & 0.009 & 0.005 & 0.004 \\
\hline Elemental Mercury Emissions $\left(\mu \mathrm{g} / \mathrm{m}^{3}\right)$ & 1.145 & 1.131 & 2.26 & 1.958 \\
\hline Oxidized Mercury Emissions $\left(\mu \mathrm{g} / \mathrm{m}^{3}\right)$ & 4.909 & 3.658 & 9.109 & 7.527 \\
\hline Total Mercury Emissions $\left(\mu \mathrm{g} / \mathrm{m}^{3}\right)$ & 6.070 & 4.798 & 11.374 & 9.489 \\
\hline
\end{tabular}


Table 4. Summary of results for the stack.

\begin{tabular}{|c|c|c|c|c|}
\hline Test Number & 2 & 3 & 4 & 5 \\
\hline Duct Flow Rate (acfm) & 783,470 & 799,894 & 816,248 & 827,442 \\
\hline$\% \mathrm{O}_{2}(\% \mathrm{Vol})$ & 4.2 & 4.2 & 4.6 & 4.4 \\
\hline Duct Temperature $(\mathrm{F})$ & 121 & 123 & 121 & 127 \\
\hline Particle Bound Mercury Emissions $\left(\mu \mathrm{g} / \mathrm{m}^{3}\right)$ & 0.026 & 0.077 & 0.016 & 0.081 \\
\hline Elemental Mercury Emissions $\left(\mu \mathrm{g} / \mathrm{m}^{3}\right)$ & 1.489 & 1.278 & 2.433 & 2.165 \\
\hline Oxidized Mercury Emissions $\left(\mu \mathrm{g} / \mathrm{m}^{3}\right)$ & 0.662 & 0.481 & 1.142 & 0.806 \\
\hline Total Mercury Emissions $\left(\mu \mathrm{g} / \mathrm{m}^{3}\right)$ & 2.177 & 1.836 & 3.591 & 3.052 \\
\hline
\end{tabular}

Figures 13 and 14 show $\mathrm{Hg}$ concentrations in flue gas for blend and coal firing at different locations. Typical of bituminous coals, most $\mathrm{Hg}$ in the gas phase at ESP inlet and outlet is present in the oxidized form. Total mercury at the stack is significantly lower than that before wet scrubber and present mostly in the elemental form.

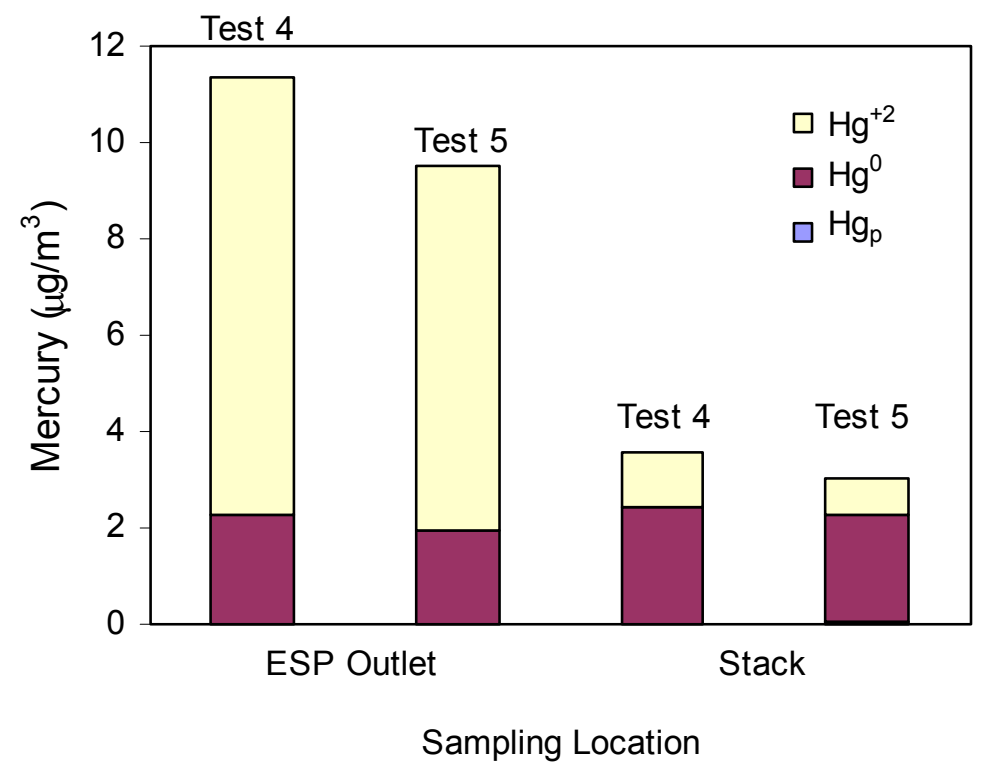

Figure 13. Mercury emissions for blend firing. 


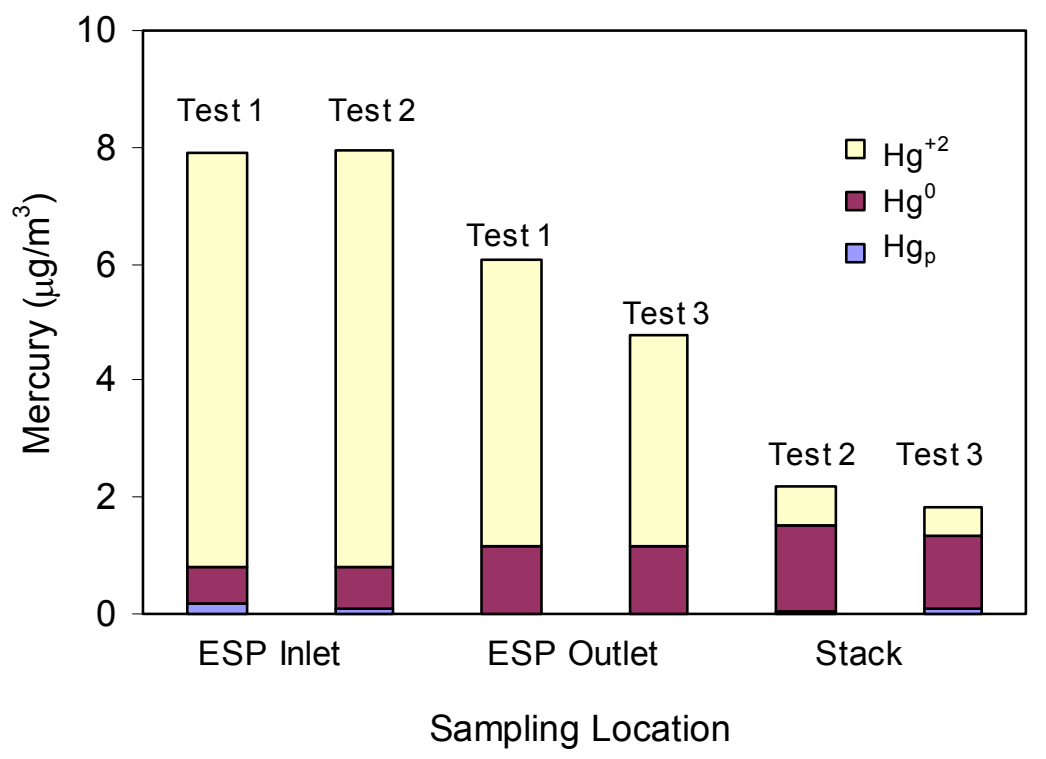

Figure 14. Mercury emissions for coal firing.

Figures 15 and 16 show efficiencies (defined as the difference between theoretical $\mathrm{Hg}$ concentration in the gas phase calculated using fuel feed rate and fuel $\mathrm{Hg}$ content and that measured) of Hg removal and $\mathrm{Hg}$ emissions for coal and blend firing. Testing showed (Figure 16a) that $\mathrm{Hg}$ removal at ESP inlet was small. Mercury emissions at ESP inlet agreed with the theoretical value within $\pm 15 \%$ (Figure 16b). This suggests that practically all $\mathrm{Hg}$ present in coal is released into flue gas during combustion process and very little $\mathrm{Hg}$ if any is absorbed on bottom ash. Mercury removal at ESP outlet and at the stack was $30-45 \%$ and $70-80 \%$, respectively. These data agree well with average $\mathrm{Hg}$ removal efficiencies of $46 \%$ and $81 \%$ reported by utilities for bituminous coal for similar configurations in respond to EPA Information Collection Request ${ }^{5}$. 

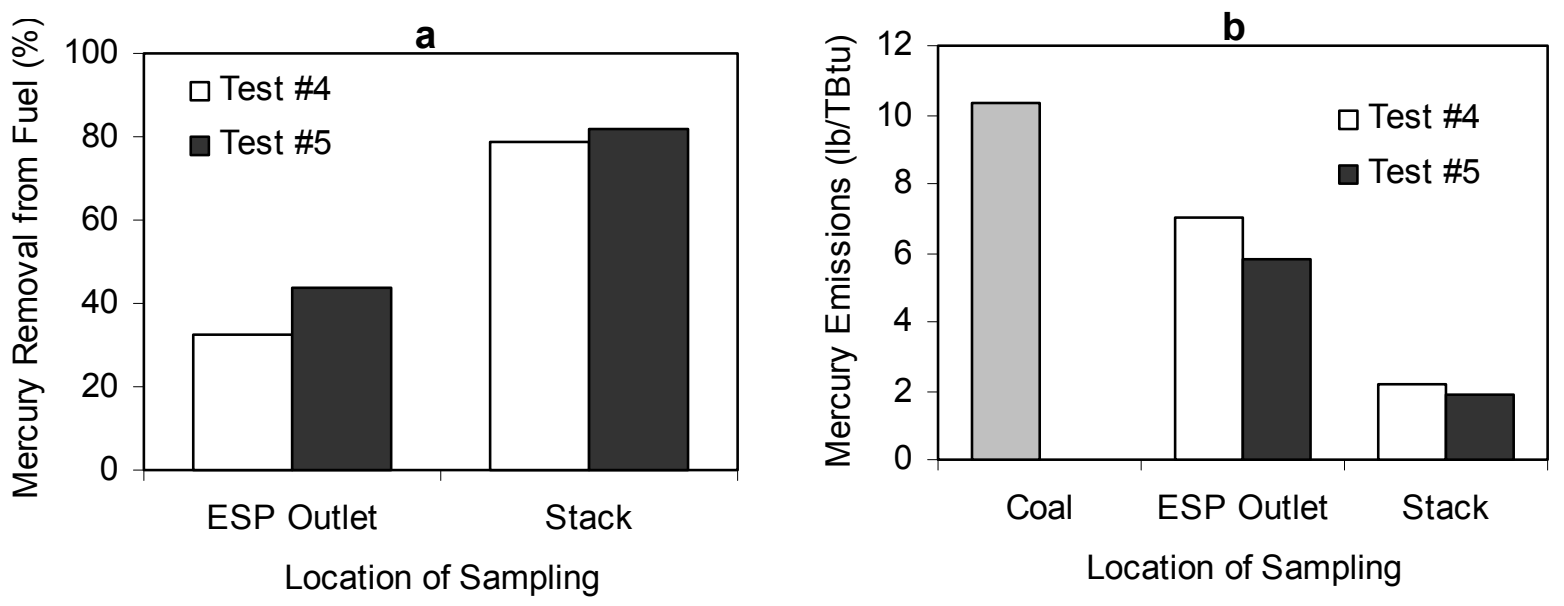

Figure 15. Mercury removal efficiencies (a) and Hg emissions (b) for coal firing.
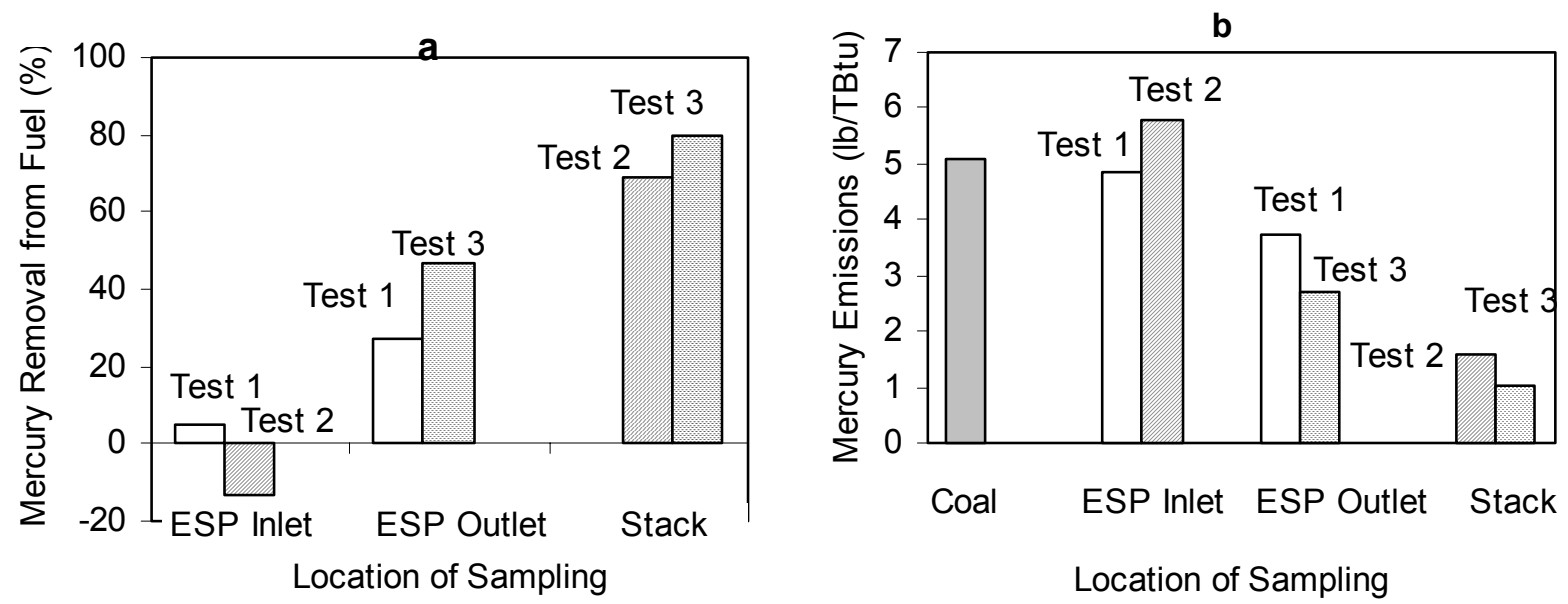

Figure 16. Mercury removal efficiencies (a) and $\mathrm{Hg}$ emissions (b) for blend firing.

Incremental efficiency of $\mathrm{Hg}$ removal across FGD (defined as the difference between $\mathrm{Hg}$ concentration at ESP outlet and stack) was in the range of $65-70 \%$ (Figures 15a and 16a). Reduction in concentration of the oxidized Hg was about $90 \%$. However, about $20 \%$ of the oxidized $\mathrm{Hg}$ was reduced to elemental across the scrubber. As a result, elemental $\mathrm{Hg}$ at the stack was about $70 \%$ of total $\mathrm{Hg}$ emissions (figures 13 and 14).

\subsection{Comparison of Pilot-Scale and Baseline Measurements}

Figures 17 and 18 show comparison of $\mathrm{Hg}$ removal efficiencies measured at ESP outlet in full- and pilot-scale for coal and blend firing. Figures 17 and 18 show that full-scale data are in agreement with pilot-scale measurements for both fuels suggesting that BSF adequately simulates thermal environment of Green Unit 2. Figure 17 also demonstrates that some improvement in $\mathrm{Hg}$ 
removal can be achieved for coal firing by increasing LOI to 6-10\%. Comparison (Figure 18) of baseline and pilot-scale measurements for blend firing suggests that LOI increase above $8-9 \%$ achieved in baseline measurements will result in additional $20-30 \% \mathrm{Hg}$ removal improvement.

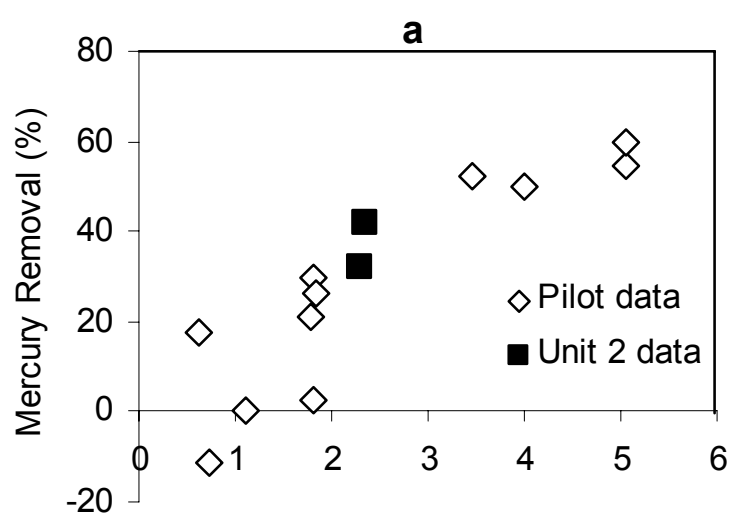

LOI $(\%)$

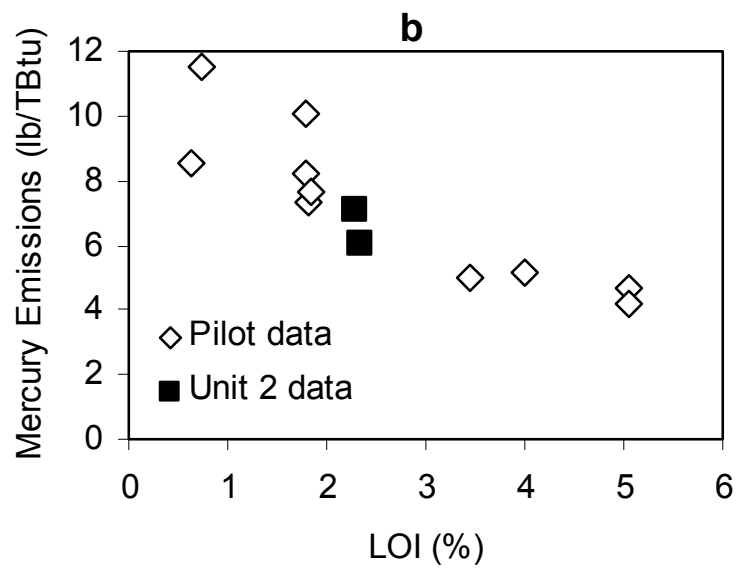

Figure 17. Comparison of pilot- (open symbols) and full-scale (filled symbols) data for OFA tests for $\mathrm{Hg}$ removal efficiency (a) and $\mathrm{Hg}$ emissions (b) for coal firing.

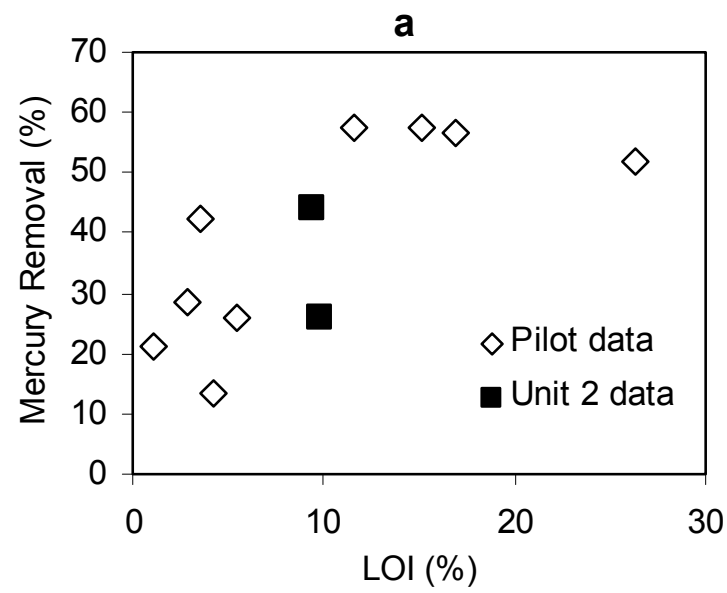

Figure 18. Comparison of pilot- (open symbols) and full-scale (filled symbols) data for OFA tests for $\mathrm{Hg}$ removal efficiency (a) and $\mathrm{Hg}$ emissions (b) for blend firing.

Figures 19 and 20 show good agreement on $\mathrm{Hg}$ partition measured in full- and pilot-scale testing. Data demonstrate that at ESP outlet oxidized $\mathrm{Hg}$ comprises about $80 \%$ of total $\mathrm{Hg}$. 


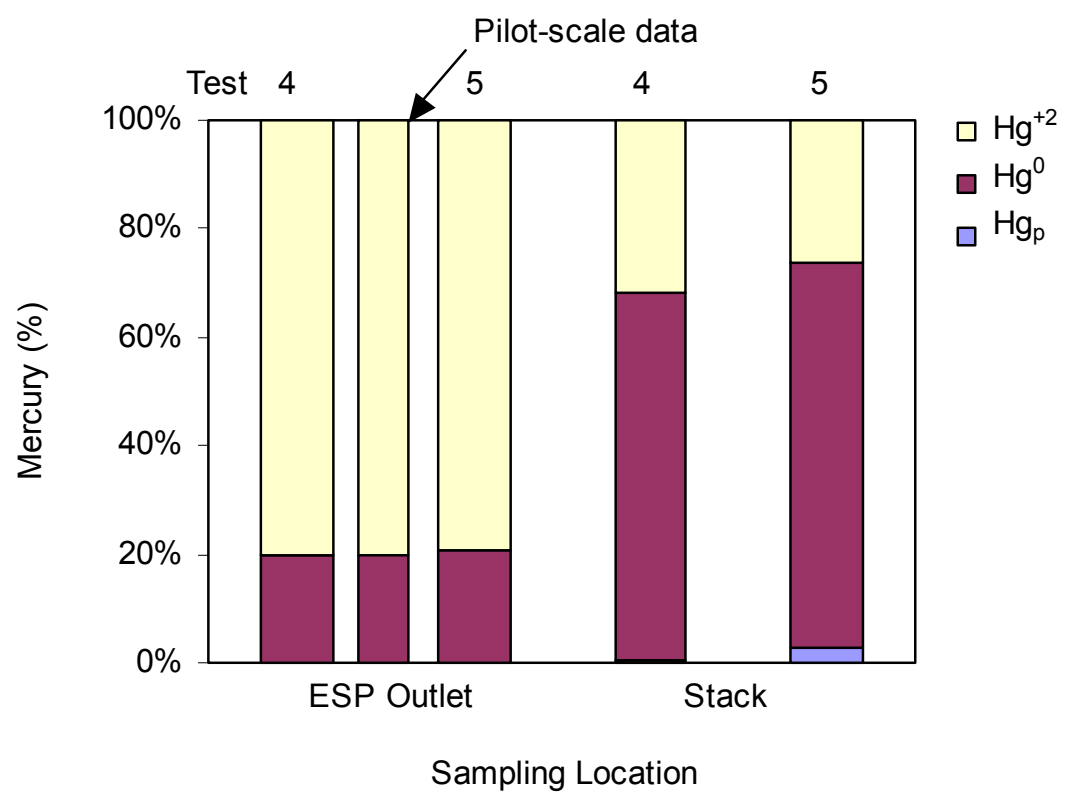

Figure 19. Mercury partition in full- and pilot-scale tests for coal firing.

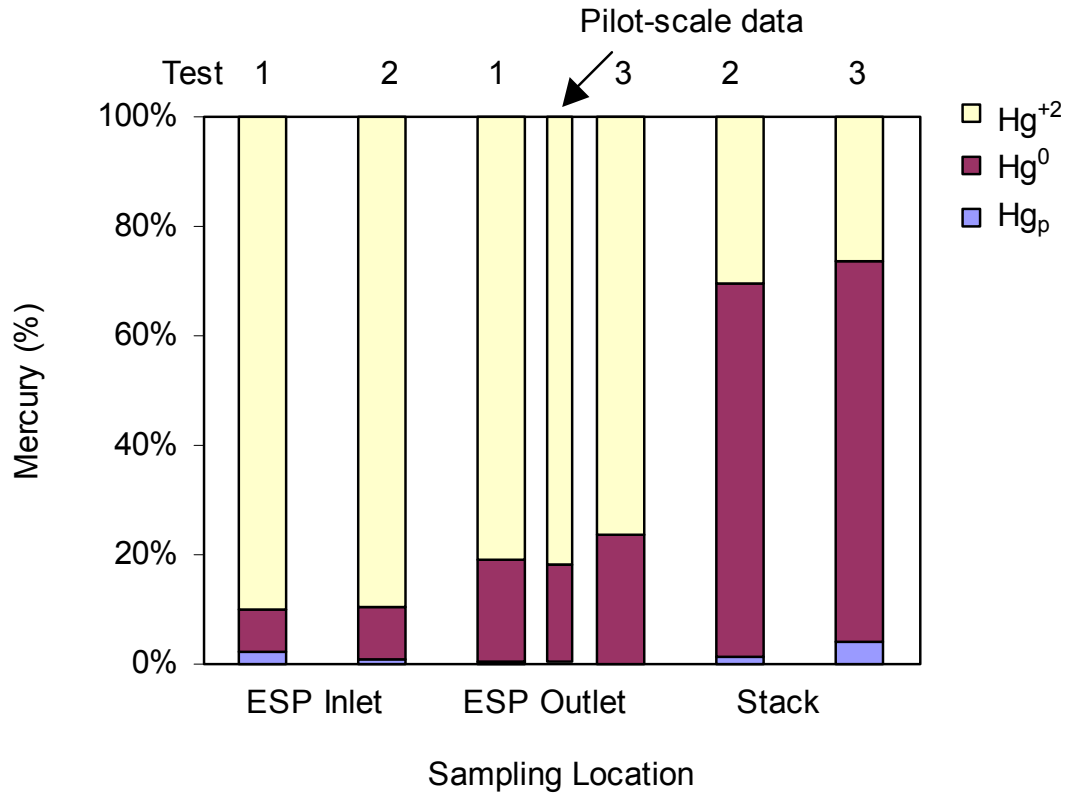

Figure 20. Mercury partition in full- and pilot-scale tests for blend firing.

Baseline testing demonstrated that efficiencies of $\mathrm{Hg}$ reduction for coal and blend firing were similar. Mercury reductions at ESP outlet and stack were 30-45\% and 70-80\%, respectively. However, since Hg content in coal was higher than that in the blend, Hg emissions were lower for blend firing. Mercury emissions at ESP outlet were 5.8-6.9 lb/TBtu and 2.7-3.7 lb/TBtu for coal and blend firing, respectively. Mercury emissions at the stack were 1.8-2.2 lb/TBtu and 1.0-1.5 
lb/TBtu for coal and blend firing, respectively. Testing also demonstrated that OFA system operation at 22\% air resulted in 10\% and 5\% incremental increase in $\mathrm{Hg}$ removal efficiencies at ESP outlet and stack, respectively. Testing demonstrated that about $80 \%$ of Hg at ESP outlet was present in the oxidized form. Most Hg at the stack was present in the elemental form. Results of baseline testing of Hg reduction and speciation in flue gas agree with pilot-scale data. 


\subsection{Mercury Emissions In Unit 2 Under Reburning Conditions}

The next task after characterizing baseline $\mathrm{Hg}$ emissions in Unit 2 was to measure $\mathrm{Hg}$ emissions under reburning conditions. These tests were conducted in January 2004 and focused on coal firing, although limited data on blend firing were also obtained. Although typically WKE does not operate reburning system during that time of the year, it was activated and made available for the duration of testing.

\subsection{Mercury Emissions in Unit 2 In Reburning}

The test program consisted of 8 tests with the boiler operating under nominal full and reduced load conditions. Table 5 shows a matrix of the test program. The boiler was configured in the reburning firing configuration. Tests 1 and 2 were conducted with the boiler firing the coal blend (see Attachment I Table I-4 for details on fuel composition). Tests 3 through 8 were conducted with the boiler firing 100\% coal. For Tests 7 and 8, boiler load was reduced to measure the impact of ESP temperature on $\mathrm{Hg}$ emissions.

Manual $\mathrm{Hg}$ sampling using the Ontario Hydro Method was performed by Metco Environmental at three locations: the ESP inlet, the ESP outlet, and the stack. Fuel samples were collected from each mill, fly ash was collected from the economizer exit duct, and hopper ash was collected from the ESP hoppers during each test. To closely monitor boiler operations, EER also measured $\mathrm{CO}$ and $\mathrm{O}_{2}$ on a dry basis continuously during each test at the economizer exit duct. All measurements were made on the boiler's East side duct. Data collection and sampling procedure was the same as in the baseline testing (Section 3.2). A summary of the operating data is included in Attachment I Table I-5. Table I-5 also includes data on $\mathrm{CO}$ emissions, $\mathrm{O}_{2}$ concentrations and LOI.

Mercury emissions were measured using the Ontario Hydro Method, Revised July 7, 1999. Three tests were conducted at ESP inlet, eight at ESP outlet, and five at the stack. Tables 6 - 9 show results of Ontario Hydro measurements. 
Table 5. Coal reburning mercury test matrix.

\begin{tabular}{|c|c|c|c|c|c|c|c|c|}
\hline \multicolumn{2}{|c|}{ Test } & Fuel & \multirow{2}{*}{$\begin{array}{c}\text { Load } \\
\text { (MW) }\end{array}$} & \multirow{2}{*}{$\begin{array}{l}\text { Reburn } \\
\text { Fuel }\end{array}$} & \multirow{2}{*}{$\begin{array}{l}\text { Reburn } \\
\text { Fuel (\%) }\end{array}$} & \multicolumn{3}{|c|}{ OH Sampling } \\
\hline Date & $\begin{array}{l}\text { Test } \\
\text { No }\end{array}$ & Coal & & & & $\begin{array}{l}\text { ESP } \\
\text { Inlet }\end{array}$ & $\begin{array}{l}\text { ESP } \\
\text { Outlet }\end{array}$ & Stack \\
\hline \multirow{2}{*}{ 21-Jan-04 } & 1 & Blend & 242 & Blend & $30 \%$ & $x$ & $x$ & \\
\hline & 2 & Blend & 242 & Blend & $30 \%$ & & $x$ & $x$ \\
\hline \multirow{2}{*}{ 22-Jan-04 } & 3 & Coal & 242 & Coal & $30 \%$ & $x$ & $x$ & \\
\hline & 4 & Coal & 242 & Coal & $30 \%$ & & $x$ & $x$ \\
\hline \multirow{2}{*}{ 23-Jan-04 } & 5 & Coal & 242 & Coal & $30 \%$ & & $x$ & $x$ \\
\hline & 6 & Coal & 242 & Coal & $30 \%$ & & $x$ & $x$ \\
\hline \multirow{2}{*}{ 25-Jan-04 } & 7 & Coal & 180 & Coal & $30 \%$ & & $x$ & $x$ \\
\hline & 8 & Coal & 180 & Coal & $30 \%$ & $x$ & $X$ & \\
\hline
\end{tabular}

Figure 21 shows $\mathrm{Hg}$ concentrations in flue gas at different locations for blend firing. Typical of bituminous coals, most $\mathrm{Hg}$ in the gas phase at ESP inlet and outlet is present in the oxidized form. Total mercury at the stack is significantly lower than that before the wet scrubber and present mostly in the elemental form. Surprisingly, very little particulate bound $\mathrm{Hg}$ was measured at ESP inlet.

Table 6. Summary of results for ESP inlet duct.

\begin{tabular}{|c|c|c|c|}
\hline Test Number & 1 & 3 & 8 \\
\hline$\% \mathrm{O}_{2}(\% \mathrm{Vol})$ & 6.6 & 3.8 & 4 \\
\hline Duct Temperature $(\mathrm{F})$ & 301 & 297 & 279 \\
\hline Particle Bound Mercury Emissions $\left(\mu \mathrm{g} / \mathrm{m}^{3}\right)$ & 0.053 & 0.585 & 1.197 \\
\hline Elemental Mercury Emissions $\left(\mu \mathrm{g} / \mathrm{m}^{3}\right)$ & 0.706 & 0.681 & 0.544 \\
\hline Oxidized Mercury Emissions $\left(\mu \mathrm{g} / \mathrm{m}^{3}\right)$ & 6.063 & 10.327 & 7.403 \\
\hline Total Mercury Emissions $\left(\mu \mathrm{g} / \mathrm{m}^{3}\right)$ & 6.822 & 11.593 & 9.144 \\
\hline
\end{tabular}


Table 7. Summary of results for ESP outlet duct.

\begin{tabular}{|c|c|c|c|c|}
\hline Test Number & 1 & 2 & 3 & 4 \\
\hline$\% \mathrm{O}_{2}(\% \mathrm{Vol})$ & 7.8 & 7.8 & 7.8 & 7.8 \\
\hline Duct Temperature $(\mathrm{F})$ & 311 & 312 & 317 & 323 \\
\hline Particle Bound Mercury Emissions $\left(\mu \mathrm{g} / \mathrm{m}^{3}\right)$ & 0 & 0.03 & 0.023 & 0.037 \\
\hline Elemental Mercury Emissions $\left(\mu \mathrm{g} / \mathrm{m}^{3}\right)$ & 1.96 & 1.453 & 2.889 & 2.67 \\
\hline Oxidized Mercury Emissions $\left(\mu \mathrm{g} / \mathrm{m}^{3}\right)$ & 5.03 & 5.329 & 7.681 & 10.018 \\
\hline Total Mercury Emissions $\left(\mu \mathrm{g} / \mathrm{m}^{3}\right)$ & 6.990 & 6.812 & 10.593 & 12.725 \\
\hline
\end{tabular}

Table 8. Summary of results for ESP outlet duct.

\begin{tabular}{|c|c|c|c|c|}
\hline Test Number & 5 & 6 & 7 & 8 \\
\hline$\% \mathrm{O}_{2}(\% \mathrm{Vol})$ & 7.8 & 7.8 & 6.8 & 6.8 \\
\hline Duct Temperature $(F)$ & 334 & 356 & 307 & 270 \\
\hline Particle Bound Mercury Emissions $\left(\mu \mathrm{g} / \mathrm{m}^{3}\right)$ & 0.023 & 0.011 & 0.008 & 0.013 \\
\hline Elemental Mercury Emissions $\left(\mu \mathrm{g} / \mathrm{m}^{3}\right)$ & 3.381 & 3.413 & 2.172 & 1.574 \\
\hline Oxidized Mercury Emissions $\left(\mu \mathrm{g} / \mathrm{m}^{3}\right)$ & 12.007 & 9.654 & 10.236 & 8.599 \\
\hline Total Mercury Emissions $\left(\mu \mathrm{g} / \mathrm{m}^{3}\right)$ & 15.411 & 13.078 & 12.416 & 10.186 \\
\hline
\end{tabular}

Table 9. Summary of results for the stack.

\begin{tabular}{|c|c|c|c|c|c|}
\hline Test Number & 2 & 4 & 5 & 6 & 7 \\
\hline$\% \mathrm{O}_{2}(\% \mathrm{Vol})$ & 6.2 & 4.4 & 6.6 & 6.0 & 6.4 \\
\hline Duct Temperature $(\mathrm{F})$ & 126 & 123 & 122 & 125 & 122 \\
\hline Particle Bound Mercury Emissions $\left(\mu \mathrm{g} / \mathrm{m}^{3}\right)$ & 0.032 & 0.037 & 0.457 & 0.08 & 0.062 \\
\hline Elemental Mercury Emissions $\left(\mu \mathrm{g} / \mathrm{m}^{3}\right)$ & 2.176 & 4.905 & 3.031 & 3.883 & 3.649 \\
\hline Oxidized Mercury Emissions $\left(\mu \mathrm{g} / \mathrm{m}^{3}\right)$ & 0.446 & 0.037 & 0.021 & 1.117 & 0.556 \\
\hline Total Mercury Emissions $\left(\mu \mathrm{g} / \mathrm{m}^{3}\right)$ & 2.654 & 4.979 & 3.509 & 5.080 & 4.267 \\
\hline
\end{tabular}

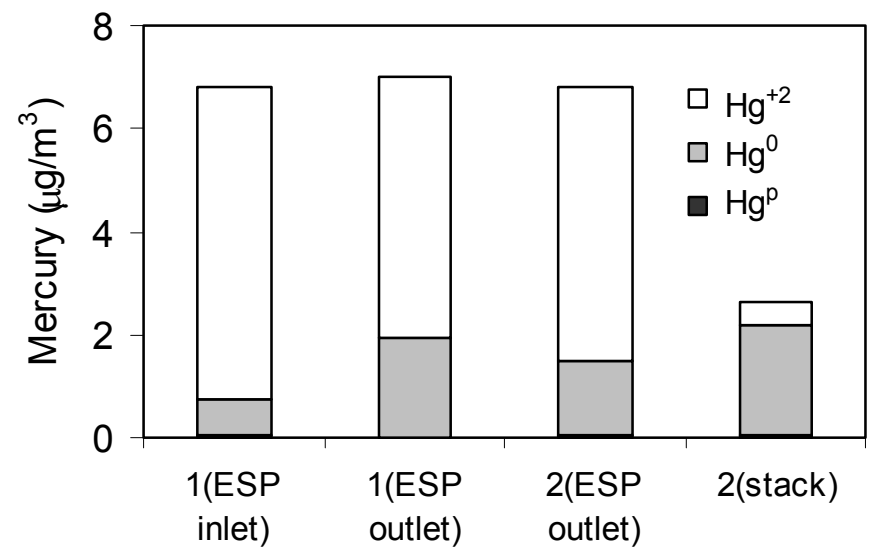

Test No

Figure 21. Mercury emissions for blend firing. 
Figures 22, 23 and 24 show $\mathrm{Hg}$ concentrations in flue gas at different locations for coal firing. As with blend firing, most $\mathrm{Hg}$ emissions at ESP inlet and outlet were present in the oxidized form while at the stack they were present mostly in the elemental form.

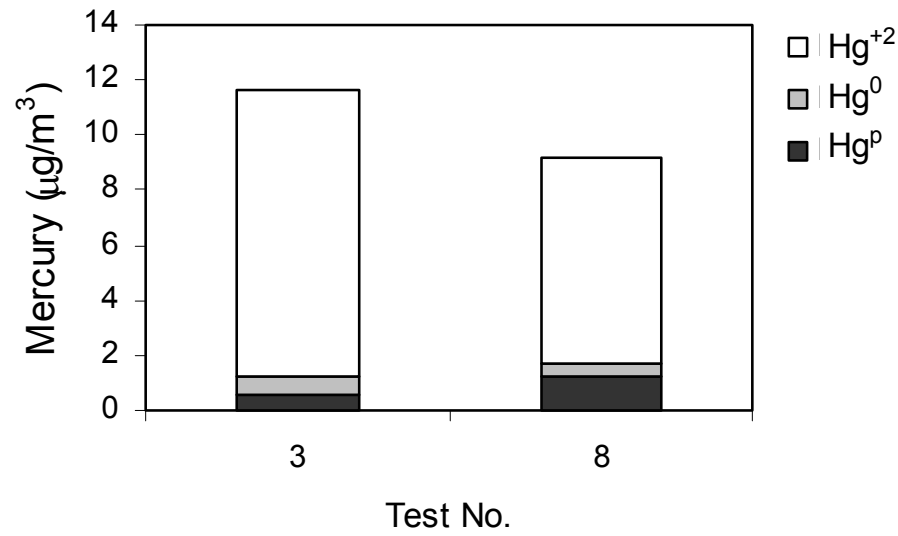

Figure 22. Mercury emissions at ESP inlet for coal firing.

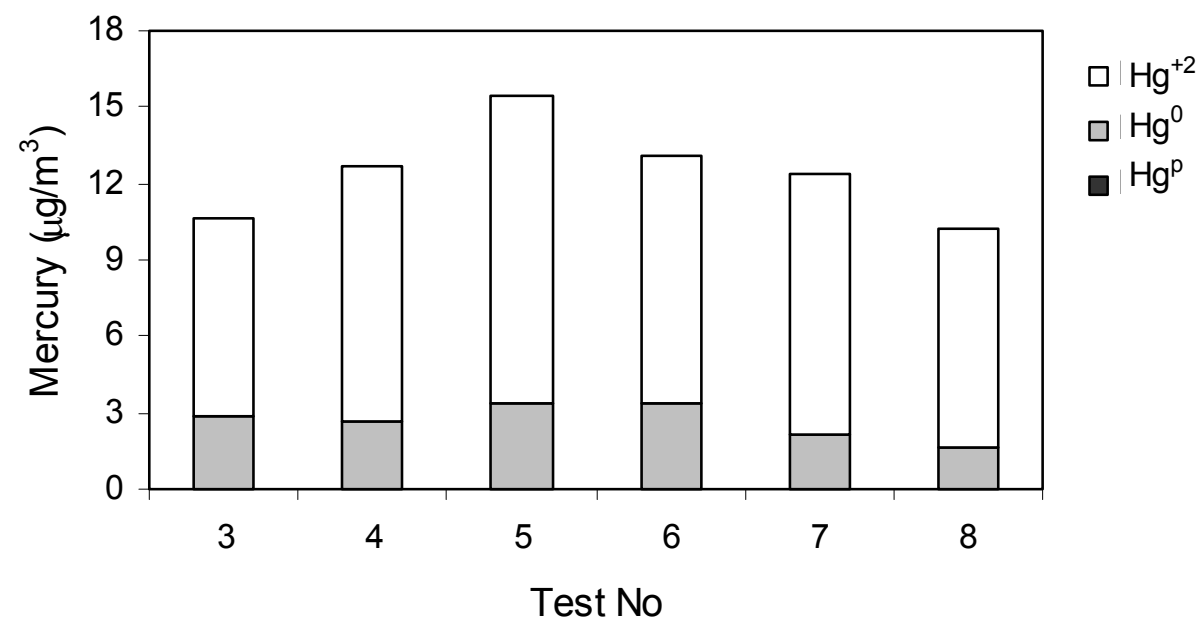

Figure 23. Mercury emissions at ESP outlet for coal firing. 


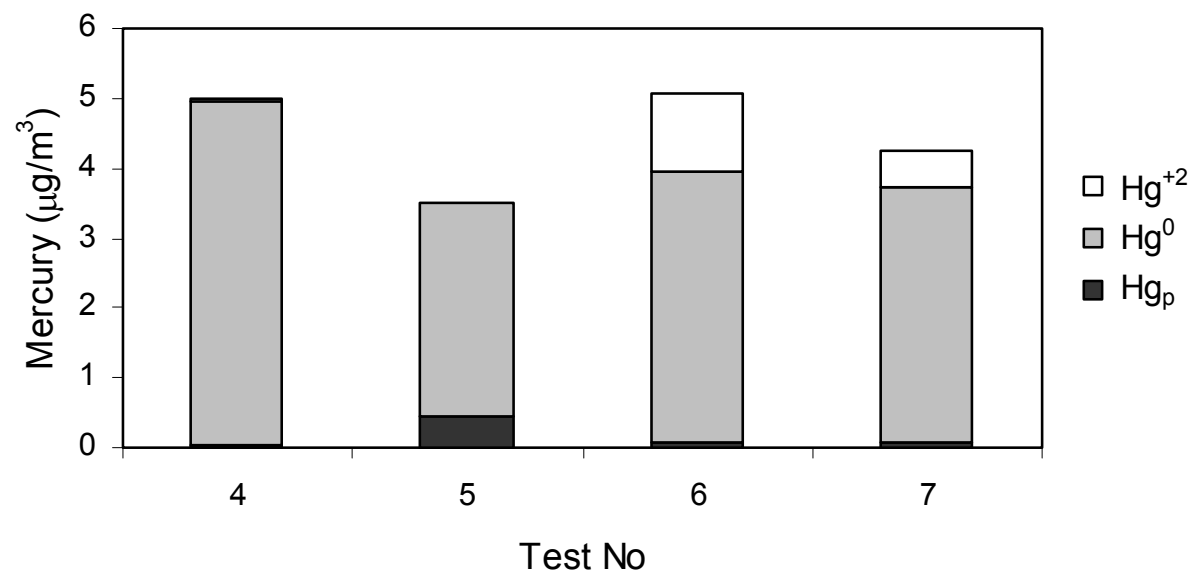

Figure 24. Mercury emissions at the stack for coal firing.

Figures 25 and 26 show efficiencies (defined as the difference between theoretical $\mathrm{Hg}$ concentration in the gas phase calculated using coal feed rate and coal $\mathrm{Hg}$ content and that measured) of $\mathrm{Hg}$ removal and $\mathrm{Hg}$ emissions for blend and coal firing.
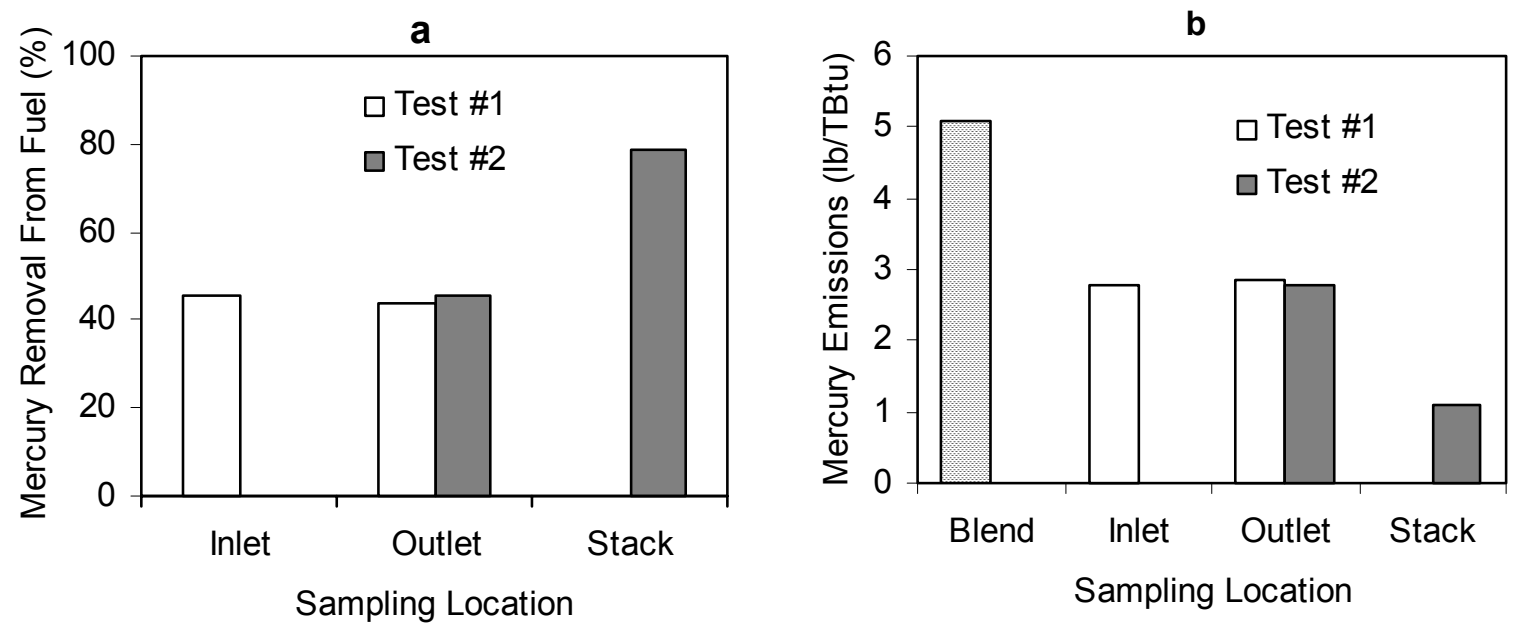

Figure 25. Mercury removal efficiencies for blend firing.

Testing showed that for both fuels efficiency of $\mathrm{Hg}$ removal at ESP inlet was about the same as that at ESP outlet, suggesting very low efficiency of $\mathrm{Hg}$ removal across ESP. Testing also showed about $30-40 \% \mathrm{Hg}$ removal at ESP inlet. These observations do not agree with results of baseline measurements of $\mathrm{Hg}$ emissions in Unit 2 and pilot-scale data that demonstrated about 30$40 \% \mathrm{Hg}$ removal across ESP and relatively small $\mathrm{Hg}$ removal at ESP inlet at similar LOIs. It is not clear what the reasons are for this disagreement. One possible explanation is that not all $\mathrm{Hg}$ 
captured by the sampling system at ESP inlet was accounted properly, resulting in higher than expected efficiencies of $\mathrm{Hg}$ removal at ESP inlet.
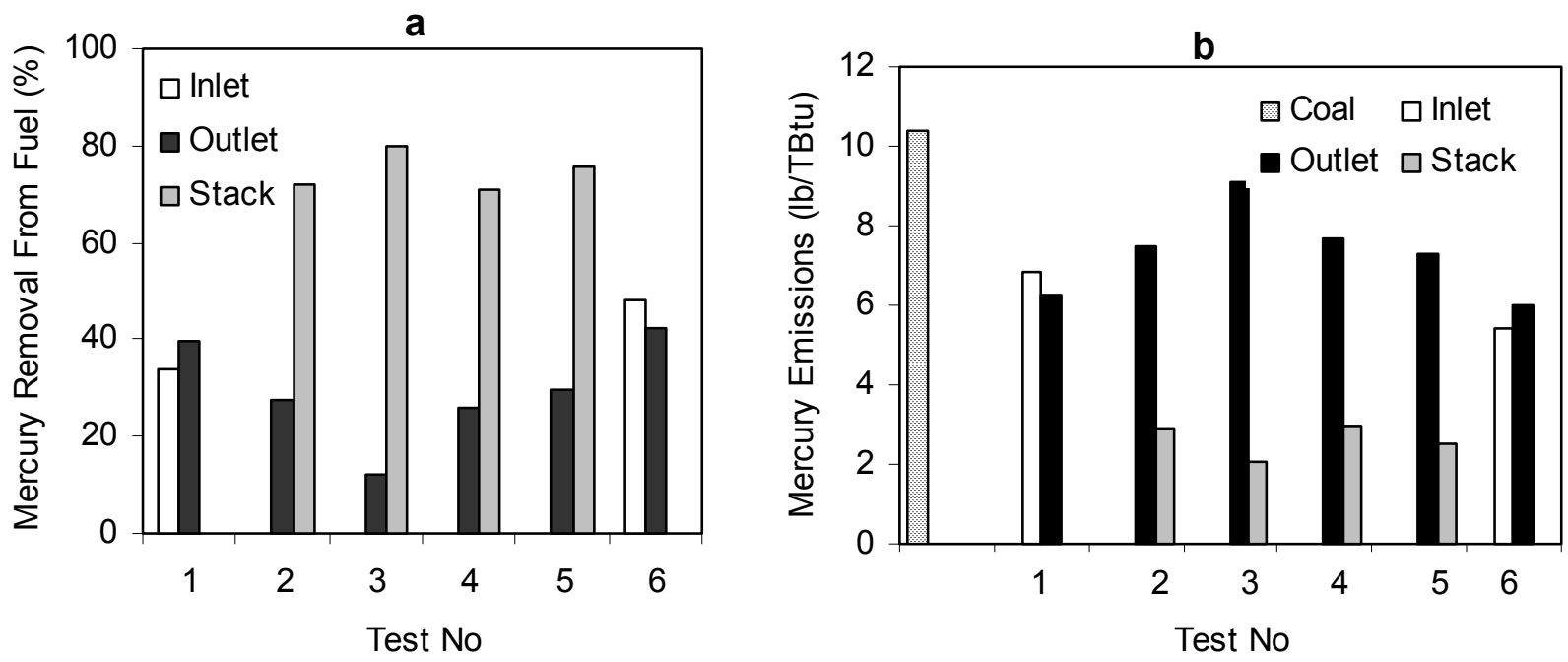

Figure 26. Mercury removal efficiencies (a) and $\mathrm{Hg}$ emissions (b) for coal firing.

Although determination of the effect of the ESP temperature on $\mathrm{Hg}$ removal was not the primary goal of these tests, variations in the boiler operation conditions and load resulted in changes in flue gas temperature at ESP inlet, providing data on $\mathrm{Hg}$ removal efficiencies in the temperature range of $270-350^{\circ} \mathrm{F}$. Pilot-scale testing demonstrated that decreasing ESP temperature improved $\mathrm{Hg}$ removal. Figure 27 shows data on the effect of temperature on $\mathrm{Hg}$ removal and emissions. Figure 27 shows that $\mathrm{Hg}$ reduction improved with decrease in ESP temperature.
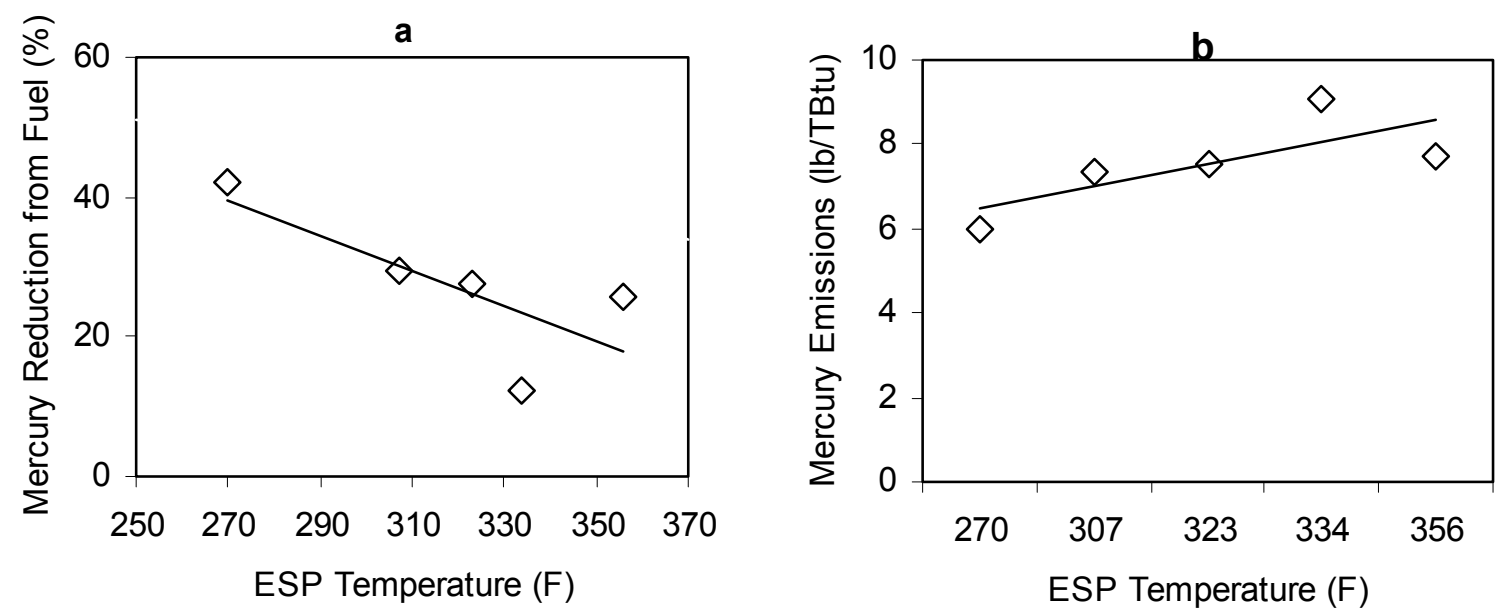

Figure 27. Effect of temperature on $\mathrm{Hg}$ removal (a) and $\mathrm{Hg}$ emissions (b) for coal firing. 
Figure 28 shows dependence of fly ash surface area on carbon in ash content for coal and blend firing. Fly ash surface area is one of the factors that determines fly ash reactivity towards $\mathrm{Hg}$. Figure 28 demonstrates that combustion staging not only improves fly ash reactivity by increasing carbon in ash content, but it also increases fly ash surface area. Figure 28 demonstrates that increase in surface area is affected by fuel properties: it is higher for coal than for the blend.

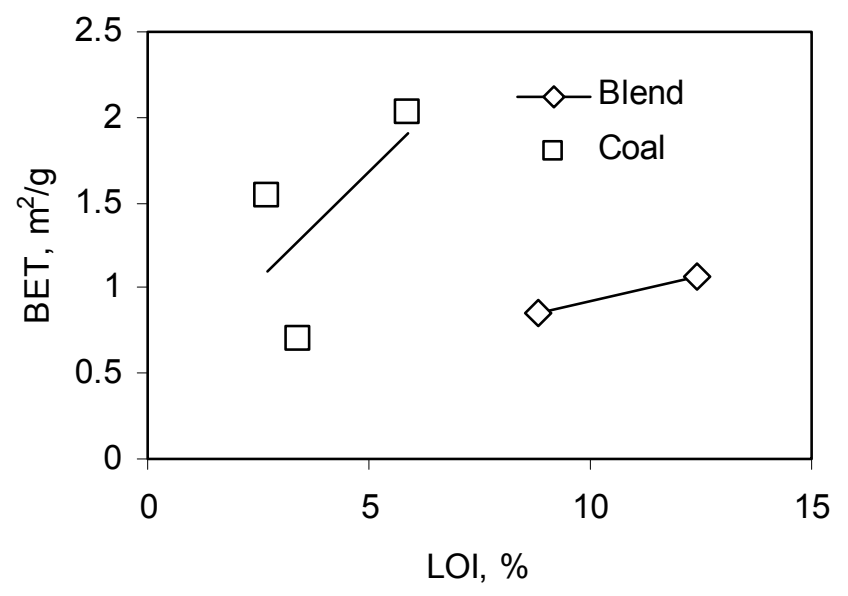

Figure 28. Dependence of fly ash surface area on LOI.

Figure 29 shows results of $\mathrm{NO}_{\mathrm{x}}$ measurements under baseline, reburning, and optimized reburning conditions.

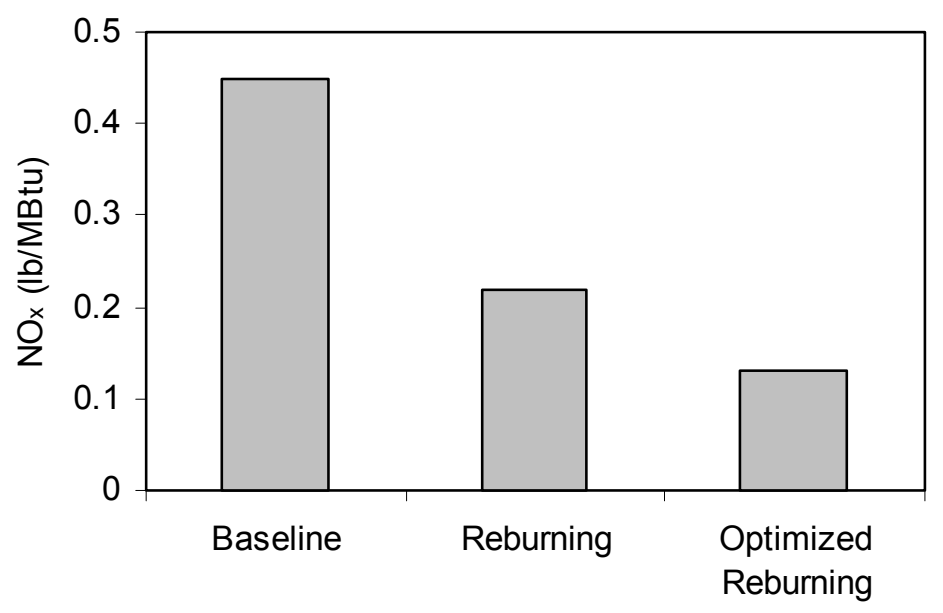

Figure 29. $\mathrm{NO}_{\mathrm{x}}$ emissions in Unit 2.

Figure 29 shows that optimized reburning reduced $\mathrm{NO}_{\mathrm{x}}$ emissions by almost $70 \%$. 
Typically, $\mathrm{NO}_{\mathrm{x}}$ reduction efficiency in reburning is in the range of $40-60 \%$. These results demonstrate importance of combustion optimization for reduction of $\mathrm{NO}_{\mathrm{x}}$ emissions and improved plant efficiency.

\subsection{Comparison with Baseline and Pilot-Scale Data}

Figures 30 and 31 show comparison of $\mathrm{Hg}$ removal efficiencies and $\mathrm{Hg}$ emissions measured at ESP outlet in full- and pilot-scale in reburning for coal and blend firing. Figures 30 and 31 demonstrate that full-scale data are in general agreement with pilot-scale and baseline measurements, although data on $\mathrm{Hg}$ removal efficiency under reburning conditions for coal firing (Figure 30) are in the lower range of expected efficiencies. Measurements of $\mathrm{Hg}$ content in coal samples collected during testing (Table I-4) show high variability in $\mathrm{Hg}$ content (up to $30 \%$ variation from the average value for the coal). Proximate and ultimate analyses also showed variability in coal composition. For example, coal ash content varied from $\sim 11 \%$ in Test \#4 to $15.5 \%$ in Test \#6. This suggests that theoretical Hg content in flue gas may had varied significantly not only in different tests, but also within 2 hour period required to complete one Ontario Hydro sampling run. Thus, if not all $\mathrm{Hg}$ in coal was accounted correctly due to the variability in coal properties, this could explain relatively low efficiencies of $\mathrm{Hg}$ removal at ESP outlet.
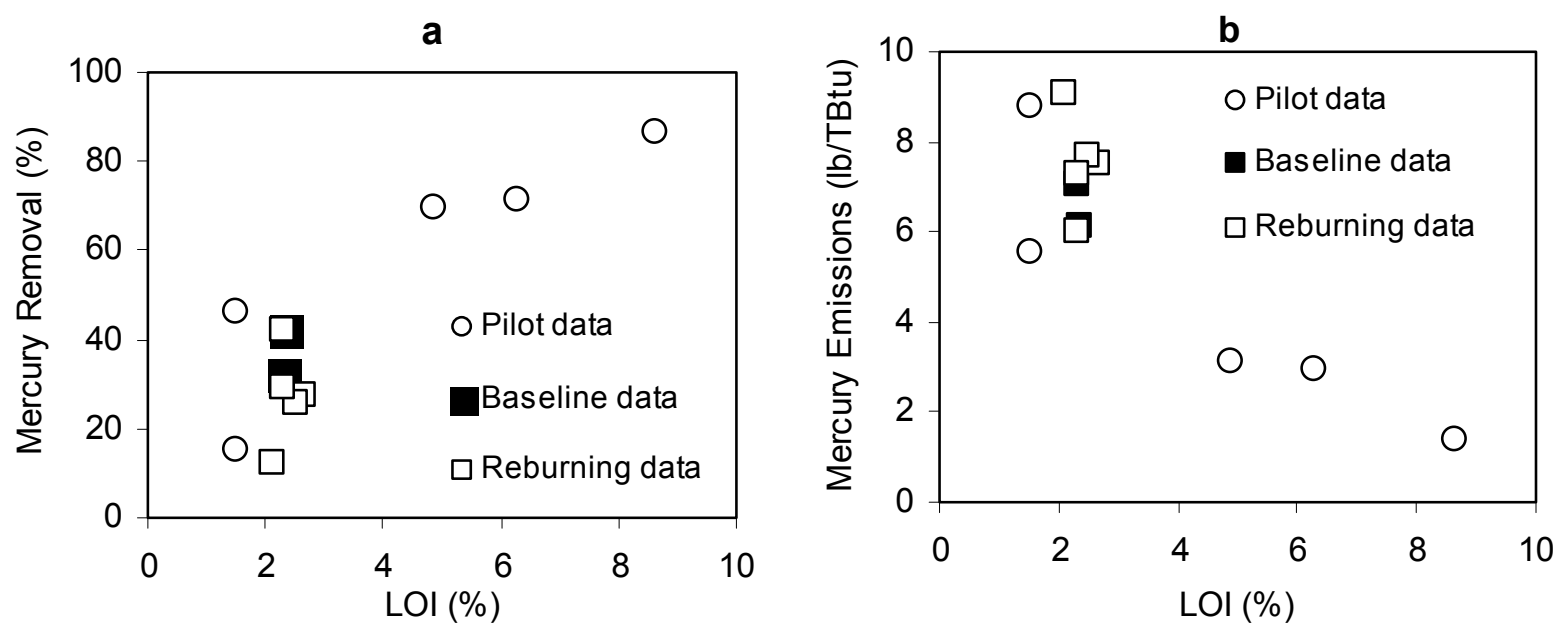

Figure 30. Comparison of $\mathrm{Hg}$ removal efficiencies measured in pilot- scale, baseline testing and reburning for coal firing. 

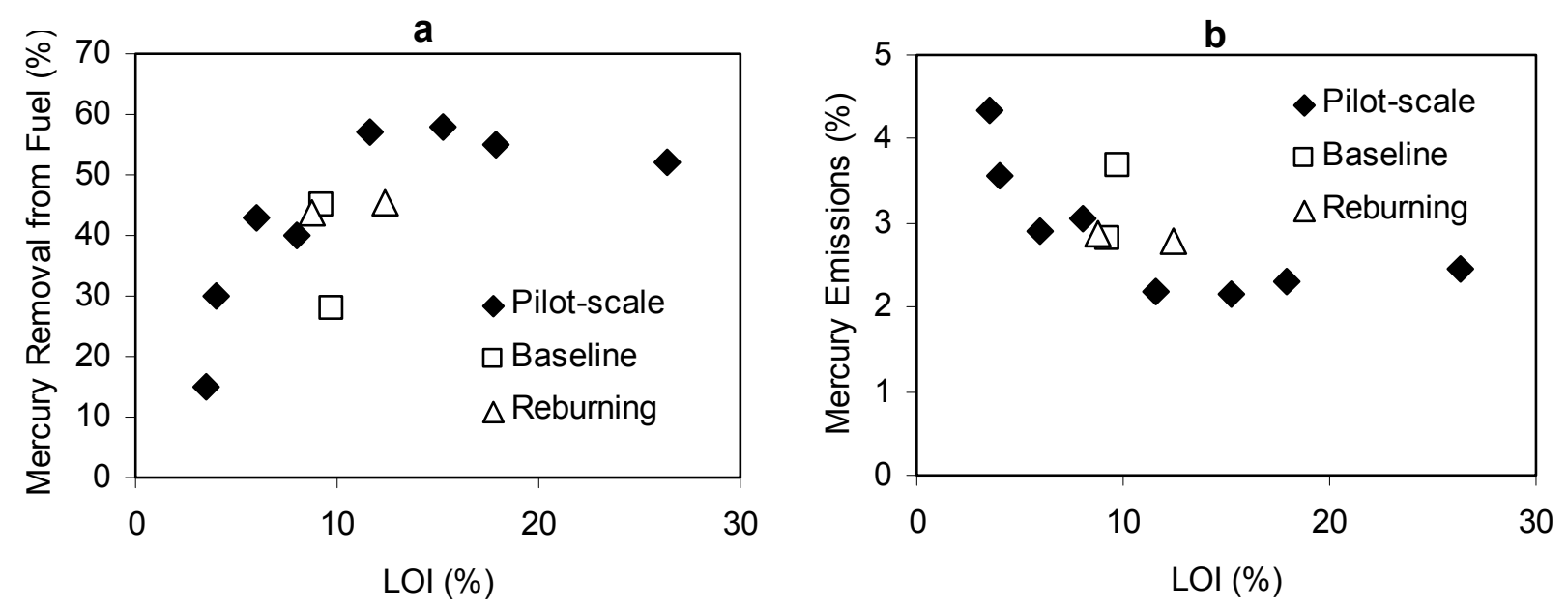

Figure 31. Comparison of $\mathrm{Hg}$ removal efficiencies (a) and $\mathrm{Hg}$ emissions (b) measured in pilotscale, baseline testing and in reburning for blend firing.

Testing of $\mathrm{Hg}$ emissions under reburning conditions demonstrated that $\mathrm{Hg}$ emissions decreased with LOI increase and ESP temperature decrease. LOI in reburning tests with coal and blend firing was about the same as in baseline firing. As a result, no significant improvement in $\mathrm{Hg}$ removal over baseline levels was measured. Mercury reduction at the ESP outlet under reburning conditions was in the range of 10-40\% and 40-45\% depending on LOI and ESP temperature for coal and blend firing, respectively. Efficiency of $\mathrm{Hg}$ removal with blend firing was higher due to significantly higher LOI in blend firing tests. Mercury reduction at the stack under reburning conditions was in the range of 70-80\% for both fuels. Mercury emissions in general were lower for blend firing due to the lower Hg content in the blend. Mercury emissions at the stack were 2-3 lb/TBtu and about $1 \mathrm{lb} /$ TBtu for coal and blend firing, respectively. Mercury emissions at the ESP outlet were 6-9 lb/TBtu and about $3 \mathrm{lb} /$ TBtu for coal and blend firing, respectively. 


\subsection{Mercury Emissions In Unit 1 Under Reburning Conditions}

Mercury testing in Unit 1 while firing coal blend was conducted to characterize $\mathrm{Hg}$ emissions at higher LOI. Since coal blend is less reactive than individual coal, LOI in blend firing is typically higher than that in coal firing. Mercury testing in Unit 1 was conducted in April 2004 when reburning system underwent $\mathrm{NO}_{\mathrm{x}}$ compliance testing.

The test program consisted of 13 tests (Table 10) with the boiler operating under nominal full load conditions at different reburning conditions. Table I-6 in Attachment I shows fuel composition and Table I-7 shows operational conditions for each test. Samples 13 a,b,c were collected while Unit 1 underwent 24 hour compliance test at constant operating conditions. Manual $\mathrm{Hg}$ sampling using the Fluegas Adsorbent Mercury Speciation (FAMS) and Frontier Total Mercury (FSTM) methods was performed by EER personnel at the ESP outlet. FAMS method is an alternative to the expensive and labor-intensive Ontario Hydro method. Extensive studies ${ }^{6,7,8}$ conducted to compare FAMS method with the ASTM promulgated Ontario Hydro Method demonstrated reasonably good agreement between these methods. FSTM is a simplified version of FAMS method that measures total $\mathrm{Hg}$.

Table 10. Test matrix for Unit 1 reburning tests.

\begin{tabular}{|c|c|c|c|}
\hline Test No & $\begin{array}{c}\text { Main and } \\
\text { Reburning Fuel }\end{array}$ & $\begin{array}{c}\text { Reburn } \\
\text { Heat input, } \\
\%\end{array}$ & Notes \\
\hline 1 & Blend & 0 & \\
2 & Blend & 30 & \\
3 & Blend & 30 & \\
4 & Blend & 30 & Other test variables \\
5 & Blend & 30 & included burners \\
6 & Blend & 25 & SR and SR in the \\
7 & Blend & 30 & primary \\
8 & Blend & 28 & combustion zone \\
9 & Blend & 29 & \\
10 & Blend & 25 & \\
11 & Blend & 30 & \\
12 & Blend & 22 & \\
13 & Blend & 30 & \\
\hline
\end{tabular}

During testing, fuel samples were collected from each mill and fly ash was collected from the economizer exit duct. Fly ash samples were analyzed to determine loss on ignition (LOI). Results of LOI measurements as well as summary of boiler operating conditions at each test are presented in Table I-7 Attachment I. To closely monitor boiler operations, EER also measured CO and $\mathrm{O}_{2}$ on a dry basis continuously during each test at the economizer exit duct. Solid sample 
collection procedure was the same as in baseline tests (Section 3.2). All measurements were made on the boiler's East side duct.

\subsection{Mercury Emissions}

Table 11 shows results of FAMS and FSTM measurements. Figures 32 and 33 show results of $\mathrm{Hg}$ measurements in a graphic form. FAMS results in Figure 32 for the total mercury are shown in black. Figure 32 demonstrates that $\mathrm{Hg}$ concentration in flue gas at ESP outlet varies from 6 to $10 \mu \mathrm{g} / \mathrm{m}^{3}$. FSTM and FAMS results for total $\mathrm{Hg}$ agree reasonably well. Except for Test 2 (Figure 33), FAMS measurements demonstrate that most $\mathrm{Hg}$ in flue gas is present in the oxidized form. Surprisingly, very little particulate bound $\mathrm{Hg}$ was measured at ESP inlet.

Table 11. Results of mercury measurements.

\begin{tabular}{|c|c|c|c|c|c|c|}
\hline \multirow{3}{*}{ Test No } & \multicolumn{3}{|c|}{ FAMS Speciation Results } & \multicolumn{2}{|c|}{ FSTM Total Hg Results } & \multirow[b]{2}{*}{$\mathrm{Hg}^{0}$} \\
\hline & $\mathrm{Hg}^{\mathrm{p}}$ & $\mathrm{Hg}^{+2}$ & $\mathrm{Hg}^{0}$ & $\mathrm{Hg}^{\mathrm{p}}$ & $\mathrm{Hg}^{+2}$ & \\
\hline & $\left(\mu \mathrm{g} / \mathrm{m}^{3}\right)$ & $\left(\mu \mathrm{g} / \mathrm{m}^{3}\right)$ & $\left(\mu \mathrm{g} / \mathrm{m}^{3}\right)$ & $\left(\mu \mathrm{g} / \mathrm{m}^{3}\right)$ & $\left(\mu \mathrm{g} / \mathrm{m}^{3}\right)$ & $\left(\mu \mathrm{g} / \mathrm{m}^{3}\right)$ \\
\hline 1 & NA & NA & NA & 0.00 & 5.79 & 5.79 \\
\hline 2 & 0.01 & 2.23 & 7.41 & NA & NA & 9.64 \\
\hline 3 & NA & NA & NA & 0.00 & 9.81 & 9.81 \\
\hline 4 & NA & NA & NA & 0.00 & 8.38 & 8.38 \\
\hline 5 & NA & NA & NA & 0.00 & 6.97 & 6.97 \\
\hline 6 & NA & NA & NA & 0.01 & 6.79 & 6.80 \\
\hline 7 & NA & NA & NA & 0.01 & 7.49 & 7.50 \\
\hline 8 & 0.01 & 5.13 & 1.88 & NA & NA & 7.02 \\
\hline 9 & NA & NA & NA & 0.00 & 6.66 & 6.66 \\
\hline 10 & NA & NA & NA & 0.00 & 6.62 & 6.62 \\
\hline 11 & 0.00 & 5.97 & 2.02 & NA & NA & 7.99 \\
\hline 12 & NA & NA & NA & 0.01 & 7.30 & 7.31 \\
\hline $13 a$ & NA & NA & NA & 0.00 & 7.57 & 7.57 \\
\hline $13 b$ & NA & NA & NA & 0.01 & 7.26 & 7.28 \\
\hline $13 \mathrm{c}$ & 0.00 & 6.00 & 1.42 & NA & NA & 7.42 \\
\hline
\end{tabular}




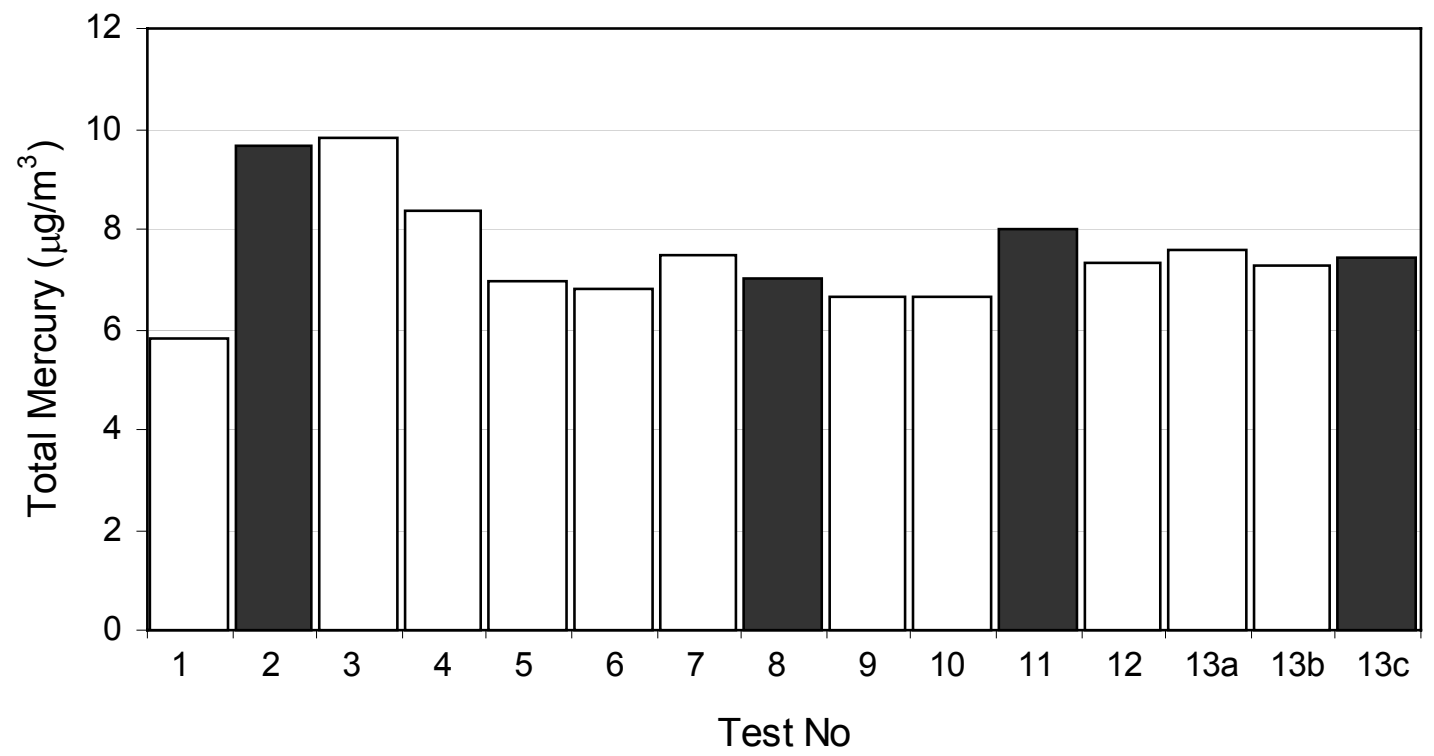

Figure 32. FAMS (filled bars) and FSTM (open bars) results for total Hg at ESP outlet.

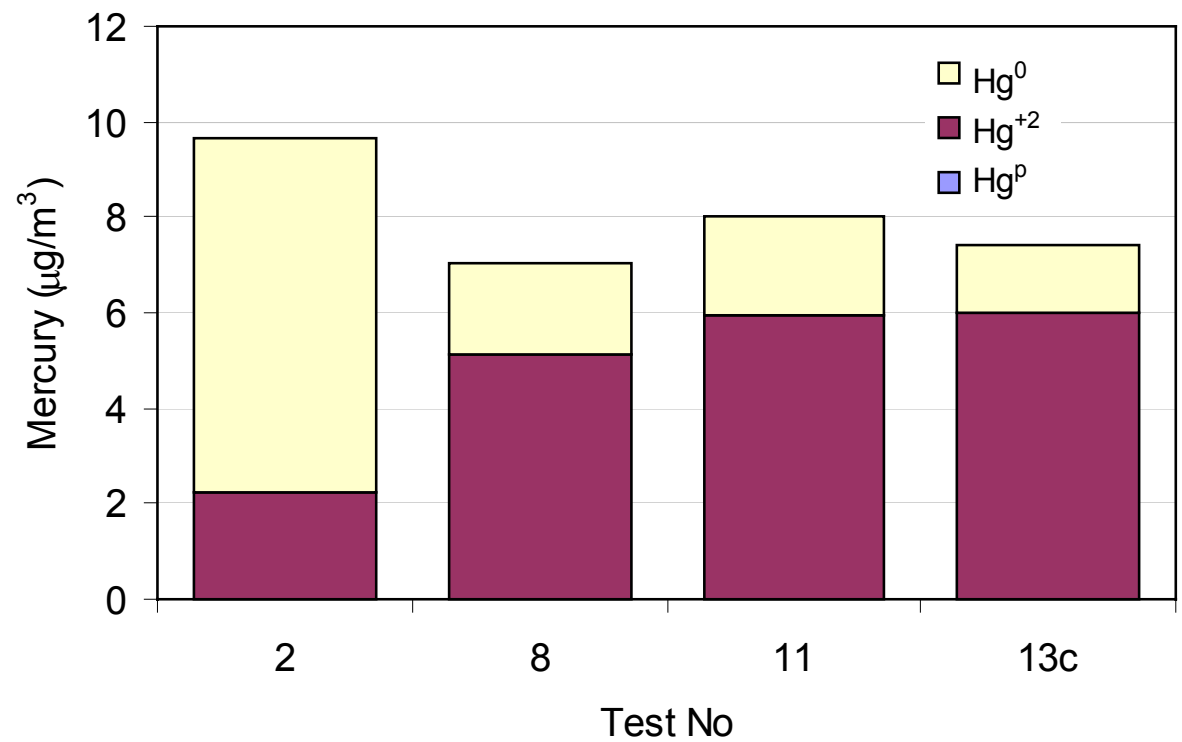

Figure 33. FAMS results for speciated $\mathrm{Hg}$ at ESP outlet.

Figure 34 shows efficiencies (defined as a difference between theoretical $\mathrm{Hg}$ concentration in the gas phase calculated using coal feed rate and coal $\mathrm{Hg}$ content and that measured) of $\mathrm{Hg}$ removal at ESP outlet. Testing showed that efficiency of $\mathrm{Hg}$ removal varied from $6 \%$ to $36 \%$. Efficiencies of $\mathrm{Hg}$ removal less than $10 \%$ were measured in tests 2 and 3, all other tests showed efficiency of $\mathrm{Hg}$ removal $20 \%$ or greater. Table I- 6 shows that $\mathrm{Hg}$ content in coal varies from 63 
ppb to $81 \mathrm{ppb}$, about $30 \%$ variation. Coal samples were taken from the mills during each test. Because of the time difference between coal sampling and actual delivery of the same coal batch to the furnace, and because the duration of each $\mathrm{Hg}$ test was only about 20 minutes, this high variability in coal $\mathrm{Hg}$ content may have resulted in relatively high uncertainty in $\mathrm{Hg}$ removal efficiencies.

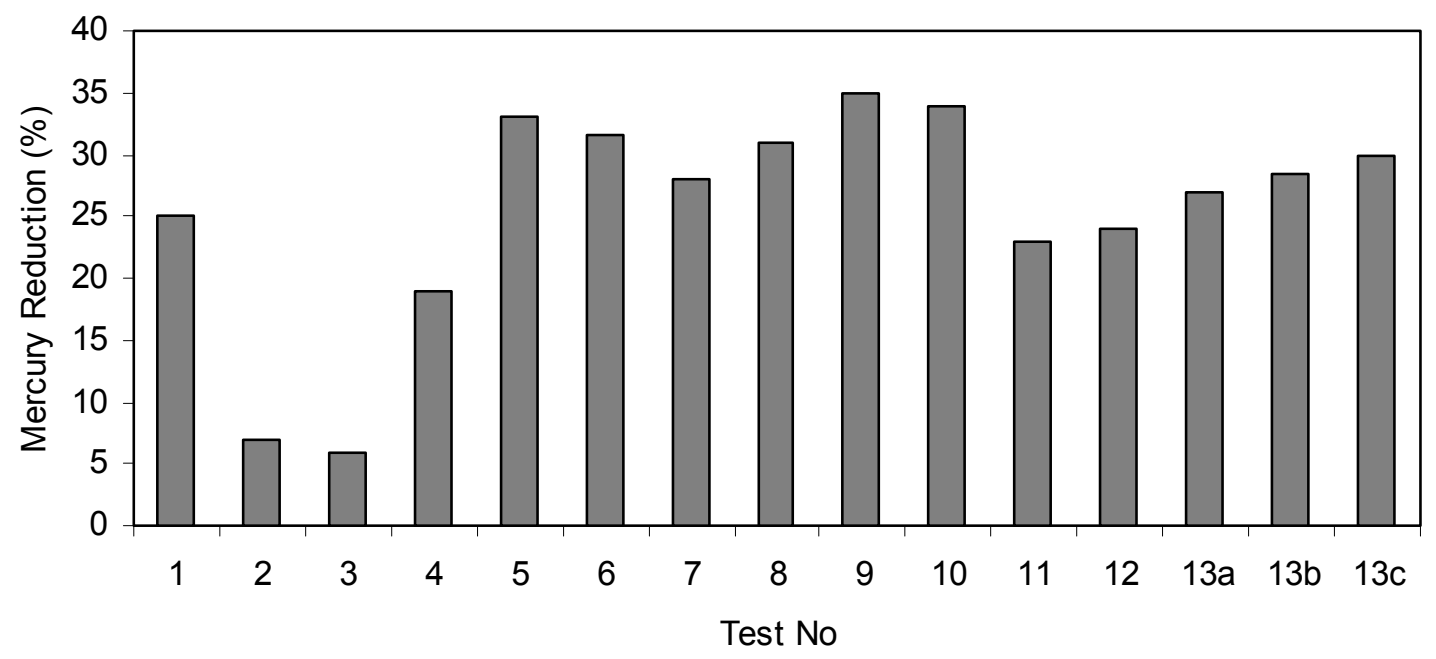

Figure 34. Mercury reduction at ESP outlet.

Figure 35 shows $\mathrm{Hg}$ emissions at ESP outlet in Unit 1 reburning tests. Average $\mathrm{Hg}$ emissions during tests were $4.8 \mathrm{lb} / \mathrm{TBtu}$.

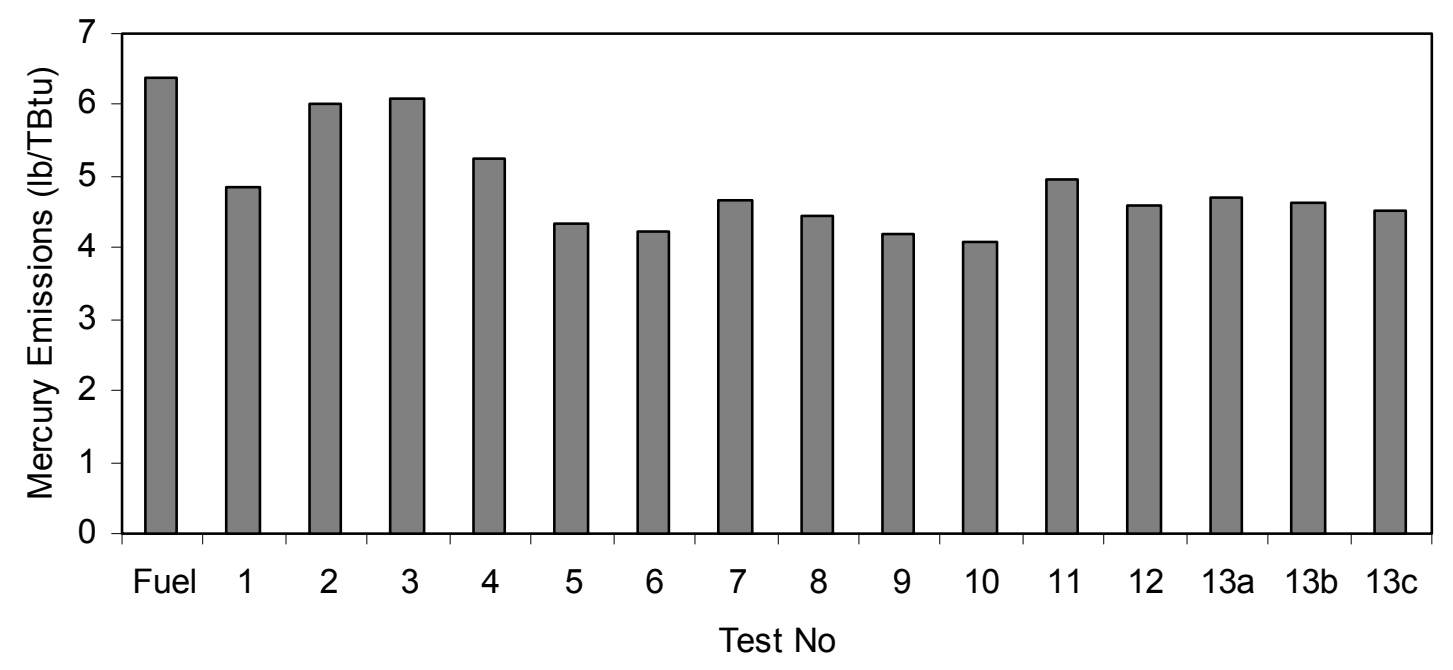

Figure 35. Mercury emissions at ESP outlet. 


\subsection{Comparison With Previously Obtained Data}

Figure 36 shows a comparison of $\mathrm{Hg}$ removal efficiencies in reburning measured at ESP outlet in Unit 1 and 2 and pilot-scale measured previously. Figure 36 shows that Unit 1 data are in general agreement with pilot-scale and Unit 2 measurements.
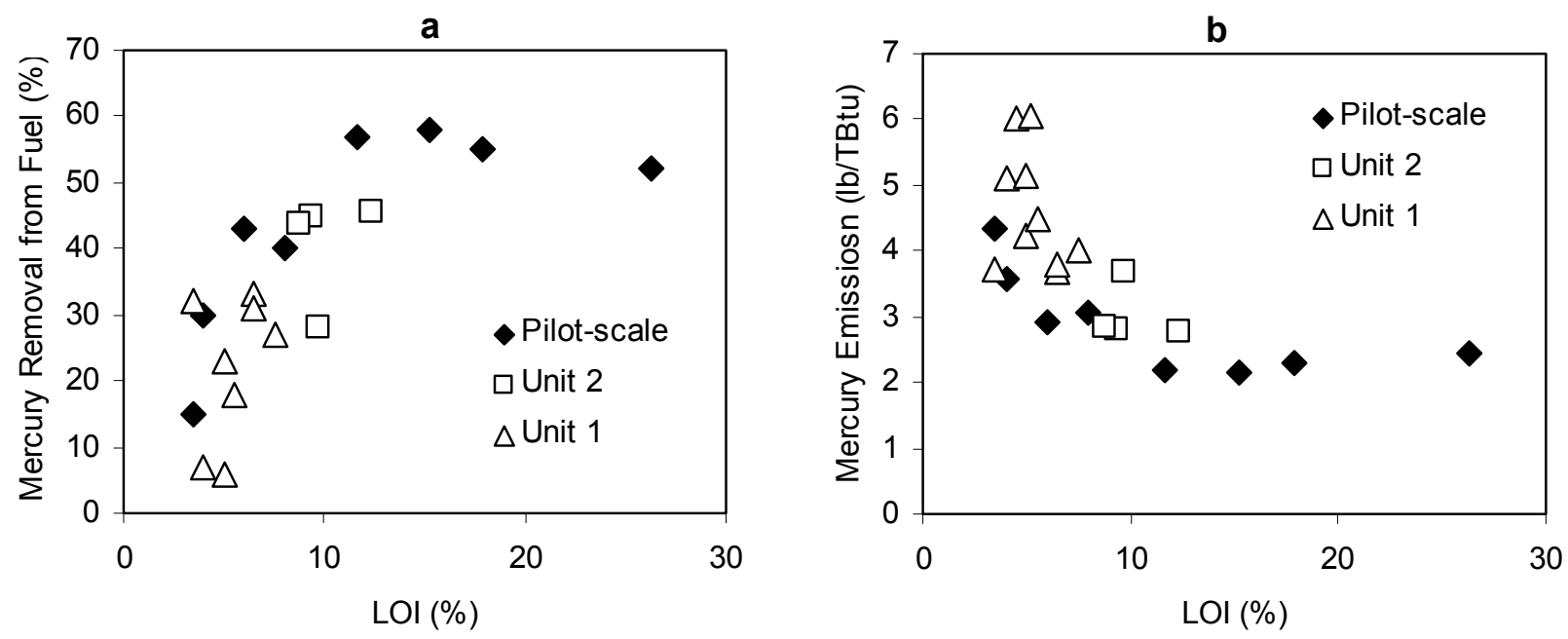

Figure 36. Comparison of pilot-scale and data on $\mathrm{Hg}$ removal (a) and $\mathrm{Hg}$ emissions (b) in reburning in Units 1 and 2 for blend firing.

Testing in Unit 1 demonstrated that Hg reduction improved with LOI increase. At LOI in the range of 4-7\% $\mathrm{Hg}$ reduction was in the range of 6-35\%. Average Hg emissions at ESP outlet during Unit 1 reburning tests were $4.8 \mathrm{lb} / \mathrm{TB} t \mathrm{u}$. 


\subsection{Optimization of Mercury Emissions in Unit 2}

Baseline testing of $\mathrm{Hg}$ emissions in Unit 2 demonstrated that $\mathrm{Hg}$ reduction was below $40 \%$ at minimum OFA and was about $45 \%$ at $22 \%$ OFA. Testing under reburning conditions demonstrated $40-45 \% \mathrm{Hg}$ removal depending on LOI. Testing also demonstrated that $\mathrm{Hg}$ removal improved as ESP temperature decreased. Both baseline and reburning results were in a good agreement with pilot-scale data suggesting that pilot-scale testing gave reasonable representation of full-scale conditions. It confirmed that the design methodology adopted in this project optimizing $\mathrm{Hg}$ reduction in pilot-scale tests and then using pilot-scale data to define optimum conditions for Hg removal in full-scale - was successful. Pilot-scale data (Section 2.2) suggested that $80 \% \mathrm{Hg}$ removal in coal reburning could be achieved for LOI in the range of $8-12 \%$ and ESP temperatures less that $300^{\circ} \mathrm{F}$. These conditions were targeted in the final reburning optimization tests that were conducted in September 2004.

Variables for the $\mathrm{Hg}$ optimization tests included fuel type, excess $\mathrm{O}_{2}$, amount of the reburning fuel, air distribution between main combustion and OFA zones, and ESP temperature. Changes in ESP temperatures were achieved by changing Unit 2 load. Goal of the testing was to achieve $80 \% \mathrm{Hg}$ reduction at ESP outlet.

The test program consisted of 17 tests with the boiler operating under nominal full and reduced load conditions. Table 12 shows a matrix of the test program. The boiler was configured in the reburning firing configuration. Tests 1-10 were conducted with the boiler firing the coal blend (see Attachment I Table I-8 for details on fuel composition). Tests 11-13 were conducted with the boiler transitioning from the coal blend to $100 \%$ coal and tests $14-17$ were conducted with the boiler firing 100\% coal. For a number of tests boiler load was reduced to measure the impact of ESP temperature on $\mathrm{Hg}$ emissions. Because of Unit 2 outage on September 19 and 20, tests on September 21 were conducted while bringing boiler to normal operational conditions resulting in ESP temperatures less than $300^{\circ} \mathrm{F}$ at full load.

Mercury measurements were conducted using a Sir Galahad Hg analyzer from PS Analytical. The analyzer was equipped with the wet chemistry conversion modules and inertia separation probe from Baldwin Inc. The probe was designed to reduce interference between fly ash and $\mathrm{Hg}$ in flue gas and was intended to be used for sampling upstream of ESP. Distances between locations of $\mathrm{Hg}$ sampling upstream and downstream of ESP and location of the analyzer were 400 $\mathrm{ft}$ and $80 \mathrm{ft}$, respectively. 
Table 12. Mercury optimization program test matrix.

\begin{tabular}{|c|c|c|c|c|c|c|c|c|c|c|c|}
\hline \multirow[b]{2}{*}{$\begin{array}{c}\text { Test } \\
\#\end{array}$} & \multirow[b]{2}{*}{ Test Date } & \multirow[b]{2}{*}{ Fuel } & \multirow[b]{2}{*}{$\begin{array}{l}\text { Load, } \\
\text { MW }_{\text {gross }}\end{array}$} & \multicolumn{2}{|c|}{ Reburning Parameters } & \multicolumn{3}{|c|}{ CEMS Data } & \multicolumn{3}{|c|}{ LOI } \\
\hline & & & & \begin{tabular}{|c|} 
Reburn Fuel \\
Heat Input (of \\
total)
\end{tabular} & $\begin{array}{l}\text { OFA (of } \\
\text { total) }\end{array}$ & $\mathrm{O}_{2}, \%$ dry & $\begin{array}{c}\mathrm{NO}_{\mathrm{x}} \\
\mathrm{lb} / \mathrm{MMBtu}\end{array}$ & $\begin{array}{c}\mathrm{CO}, \mathrm{ppm} \\
\text { dry }\end{array}$ & $\begin{array}{c}\text { LOI West } \\
\text { location, } \\
\%\end{array}$ & $\begin{array}{c}\text { LOI East } \\
\text { location, } \\
\%\end{array}$ & $\begin{array}{c}\text { LOI } \\
\text { Average }\end{array}$ \\
\hline 1 & $9 / 21 / 2004$ & Blend & 241 & $34.6 \%$ & $25.5 \%$ & 2.6 & 0.19 & 80 & 9.8 & 10.3 & 10.1 \\
\hline 2 & $9 / 21 / 2004$ & Blend & 241 & $32.9 \%$ & $27.6 \%$ & 2.7 & 0.19 & 125 & 9.2 & 10.3 & 9.7 \\
\hline 3 & $9 / 22 / 2004$ & Blend & 241 & $33.2 \%$ & $27.6 \%$ & 3.1 & 0.19 & 115 & 10.2 & 13.0 & 11.6 \\
\hline 4 & $9 / 23 / 2004$ & Blend & 180 & $26.2 \%$ & $26.1 \%$ & 4.0 & 0.15 & 68 & 8.6 & 8.2 & 8.4 \\
\hline 5 & $9 / 23 / 2004$ & Blend & 180 & $31.9 \%$ & $29.1 \%$ & 4.1 & 0.16 & 76 & 7.4 & 9.4 & 8.4 \\
\hline 6 & $9 / 23 / 2004$ & Blend & 180 & $32.2 \%$ & $28.5 \%$ & 3.6 & 0.18 & 62 & 7.3 & 7.5 & 7.4 \\
\hline 7 & $9 / 23 / 2004$ & Blend & 241 & $32.0 \%$ & $27.4 \%$ & 3.2 & 0.19 & 124 & 10.3 & 10.8 & 10.5 \\
\hline 8 & $9 / 24 / 2004$ & Blend & 198 & $32.3 \%$ & $29.2 \%$ & 3.6 & 0.18 & 70 & 8.7 & 8.6 & 8.6 \\
\hline 9 & $9 / 24 / 2004$ & Blend & 198 & $23.0 \%$ & $23.6 \%$ & 2.7 & 0.15 & 56 & 11.4 & 14.2 & 12.8 \\
\hline 10 & $9 / 24 / 2004$ & Blend & 198 & $23.0 \%$ & $21.5 \%$ & 2.7 & 0.18 & 55 & 12.6 & 11.4 & 12.0 \\
\hline 11 & $9 / 24 / 2004$ & Blend/coal & 200 & $35.6 \%$ & $27.1 \%$ & 3.5 & 0.17 & 70 & 5.1 & 4.3 & 4.7 \\
\hline 12 & $9 / 25 / 2004$ & Blend/coal & 200 & $24.7 \%$ & $23.2 \%$ & 2.7 & 0.15 & 68 & 5.9 & 4.9 & 5.4 \\
\hline 13 & $9 / 25 / 2004$ & Blend/coal & 200 & $23.9 \%$ & $22.3 \%$ & 2.3 & 0.16 & 80 & 5.0 & 5.3 & 5.1 \\
\hline 14 & $9 / 25 / 2004$ & Coal & 240 & $33.7 \%$ & $23.7 \%$ & $\mathrm{n} / \mathrm{a}$ & $\mathrm{n} / \mathrm{a}$ & $\mathrm{n} / \mathrm{a}$ & 4.0 & 4.0 & 4.0 \\
\hline 15 & $9 / 25 / 2004$ & Coal & 176 & $25.5 \%$ & $26.7 \%$ & 3.0 & 0.13 & 30 & 3.1 & 4.5 & 3.8 \\
\hline 16 & $9 / 25 / 2004$ & Coal & 150 & $29.0 \%$ & $28.1 \%$ & 4.3 & 0.12 & 25 & 2.0 & 1.9 & 2.0 \\
\hline 17 & $9 / 26 / 2004$ & Coal & 200 & $35.4 \%$ & $31.3 \%$ & 3.4 & 0.17 & 56 & 2.3 & 2.1 & 2.2 \\
\hline
\end{tabular}

To ensure that no significant $\mathrm{Hg}$ losses occurred in the sampling system, the ESP upstream and downstream probes were equipped with spanning systems that allowed introduction of a known concentration of elemental $\mathrm{Hg}$ at the tip of the sampling probe. The Teflon line between sampling probe and the module was maintained at $400^{\circ} \mathrm{F}$ to minimize $\mathrm{Hg}$ losses. The conversion module at the ESP upstream location was located within $20 \mathrm{ft}$ of the sampling probe such that only elemental $\mathrm{Hg}$ was transferred over $400 \mathrm{ft}$ to the analyzer. This arrangement was designed to reduce $\mathrm{Hg}$ losses before sampling gas reached the analyzer. Initial testing, however, showed that $\mathrm{Hg}$ concentration at ESP inlet was about half of that measured at ESP outlet. Spanning sampling system at the ESP upstream location resulted in about 50\% $\mathrm{Hg}$ recovery in the analyzer. Based on these initial tests, decision was made not to sample upstream of ESP and focus sampling efforts on the ESP downstream location. Spanning probe at ESP downstream location with elemental $\mathrm{Hg}$ showed close to $100 \% \mathrm{Hg}$ recovery.

Manual Hg sampling using the Frontier Total Mercury (FSTM) method was performed at the stack. Fuel samples were collected from each mill, fly ash was collected from the economizer exit duct, and hopper ash was collected from the ESP hoppers during each test. To closely monitor boiler operations, EER also measured $\mathrm{CO}$ and $\mathrm{O}_{2}$ on a dry basis continuously during each test at the economizer exit duct. All measurements were made on the boiler's East side duct. Data collection procedure was the same as in the baseline testing (Section 3.2). A summary of the 
operating data is included in Attachment I Table I-9. Table 11 shows data on $\mathrm{CO}$ emissions, $\mathrm{O}_{2}$, and LOI.

\subsection{Mercury Measurements}

Both tested fuels (See Table I-8) had high sulfur content. Since it is known that $\mathrm{SO}_{2}$ can reduce efficiency of $\mathrm{Hg}^{+2}$ reduction in the analyzer speciation module, a dilution system was used to reduce $\mathrm{SO}_{2}$ concentration in the sampling gas. Bottled $\mathrm{N}_{2}$ was introduced into the sampling line upstream of the speciation module. Mass flow of $\mathrm{N}_{2}$ was about two times larger than that of sample gas, resulting in factor of 3 reduction in $\mathrm{SO}_{2}$ concentration. The dilution factor was controlled by measuring $\mathrm{CO}_{2}$ concentrations in the sampling gas before and after dilution $\mathrm{N}_{2}$ flow was introduced.

Sampling arrangement also allowed for introduction of a known concentration of elemental $\mathrm{Hg}$ from the analyzer CavKit at the sampling probe. Figure 37 shows the sampling arrangement.

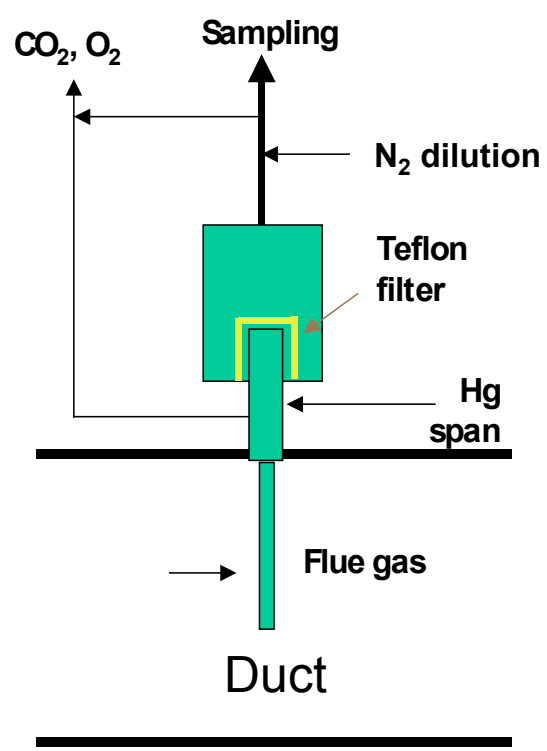

Figure 37. Sampling arrangement.

Comparison between introduced and measured $\mathrm{Hg}$ concentrations allowed quantification of $\mathrm{Hg}$ losses in the sampling system. Spanning was conducted at the beginning of each testing day. Figure 38 shows $\mathrm{Hg}$ recovery factors (defined as the amount of $\mathrm{Hg}$ measured as a percent of $\mathrm{Hg}$ introduced) for each testing day. Since the analyzer is capable of operating in modes that measure total and elemental $\mathrm{Hg}$, it allowed to determine recovery factor for total and elemental $\mathrm{Hg}$. Figure 38 demonstrates that the average recovery factor for total $\mathrm{Hg}$ was $97 \%$ suggesting that no 
significant $\mathrm{Hg}$ losses occurred in the system. Average recovery factor for elemental $\mathrm{Hg}$ was $81 \%$ suggesting that about $20 \%$ of elemental $\mathrm{Hg}$ was oxidized in the system. Most likely oxidation took place on the Teflon filter containing traces of fly ash. The filter was replaced every day to reduce potential $\mathrm{Hg}$ oxidation in the sampling system.

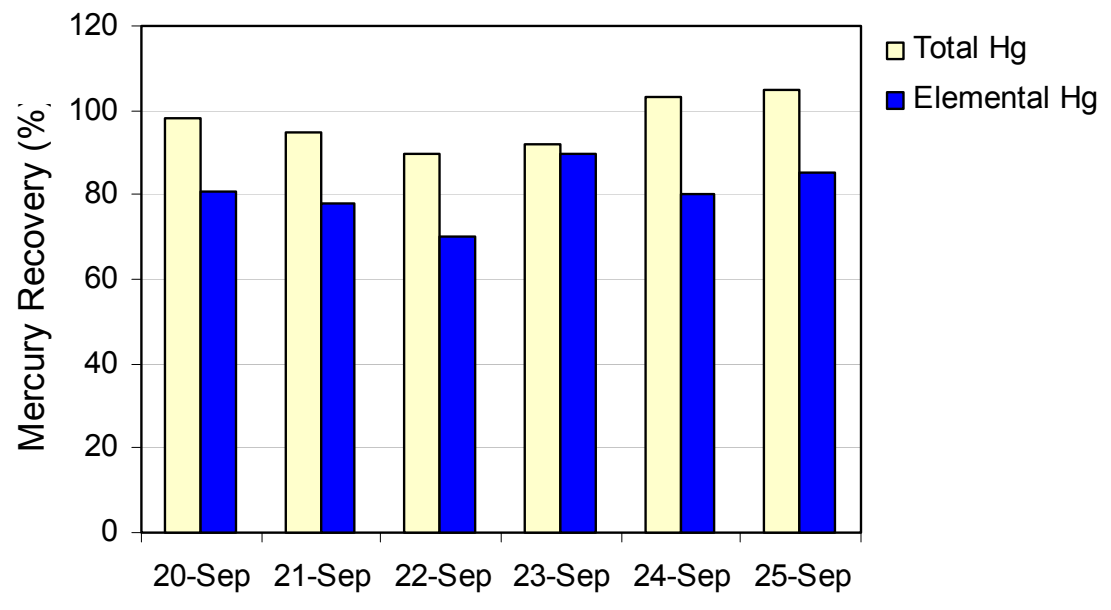

Figure 38. Recovery factors for total and elemental Hg.

Table 13 shows a summary of the $\mathrm{Hg}$ optimization tests including $\mathrm{Hg}$ removal efficiencies, $\mathrm{Hg}$ emissions, and ESP temperatures.

Figure 39 shows measured and theoretical (calculated from $\mathrm{Hg}$ in coal content and excess $\mathrm{O}_{2}$ data) $\mathrm{Hg}$ concentration in flue gas for blend firing tests on September 20-24. On September 22 the $\mathrm{Hg}$ CEM had to be taken off line for unscheduled maintenance. As a result, $\mathrm{Hg}$ data for tests 3 6 were not collected. Only total $\mathrm{Hg}$ was measured on September 21 due to problems with the speciation module. The ESP temperature in Tests $\# 1$ and $8-10$ was below $300^{\circ} \mathrm{F}$ while in Tests $\# 2$ and 3 it was higher than $310^{\circ} \mathrm{F}$. 
Table 13. Summary of $\mathrm{Hg}$ optimization tests.

\begin{tabular}{|c|c|c|c|c|}
\hline Test No & Fuel & $\begin{array}{c}\text { Hg Removal } \\
\text { Efficiency (\%) }\end{array}$ & $\begin{array}{c}\text { Hg Emissions } \\
\text { (Ib/TBtu) }\end{array}$ & $\begin{array}{c}\text { ESP } \\
\text { Temperature (F) }\end{array}$ \\
\hline 1 & Blend & 77.0 & 1.9 & 270 \\
2 & Blend & 61.0 & 3.8 & 303 \\
7 & Blend & 62.0 & 3.3 & 306 \\
8 & Blend & 75.0 & 2.1 & 290 \\
9 & Blend & 82.0 & 1.5 & 285 \\
10 & Blend & 75.0 & 2.1 & 280 \\
11 & Blend/coal & 9.5 & 11.7 & 295 \\
12 & Blend/coal & 38.1 & 8.0 & 293 \\
13 & Blend/coal & 38.0 & 8.0 & 297 \\
14 & Coal & 16.7 & 10.8 & 303 \\
15 & Coal & 13.8 & 11.2 & 289 \\
16 & Coal & 13.6 & 11.2 & 280 \\
17 & Coal & 26.1 & 9.6 & 297 \\
\hline
\end{tabular}

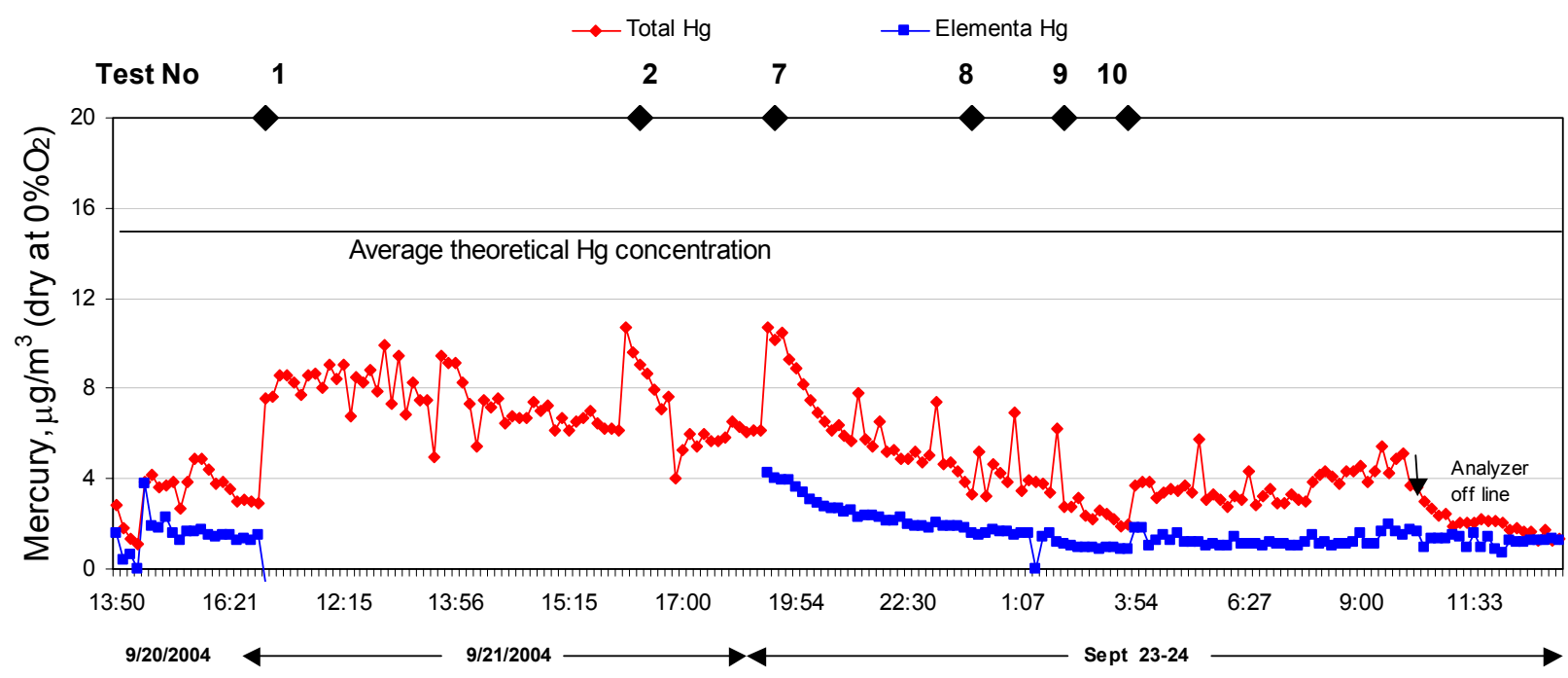

Figure 39. Results of CEM measurements for blend firing on September 20-24.

Figure 40 shows $\mathrm{Hg}$ reduction efficiencies and $\mathrm{Hg}$ emissions as determined in testing during September 20-24 for blend firing. Mercury reduction is defined as a difference between theoretical $\mathrm{Hg}$ concentration in flue gas calculated from $\mathrm{Hg}$ content in coal and unit operational conditions, and measured $\mathrm{Hg}$ concentration. Figure 40 demonstrates that $\mathrm{Hg}$ reduction was about $80 \%$ at ESP temperatures of $270-290^{\circ} \mathrm{F}$ (Tests \#1, 8-10) and was about $60 \%$ at ESP temperatures $300^{\circ} \mathrm{F}$ and higher (Tests \#2 and 7). 

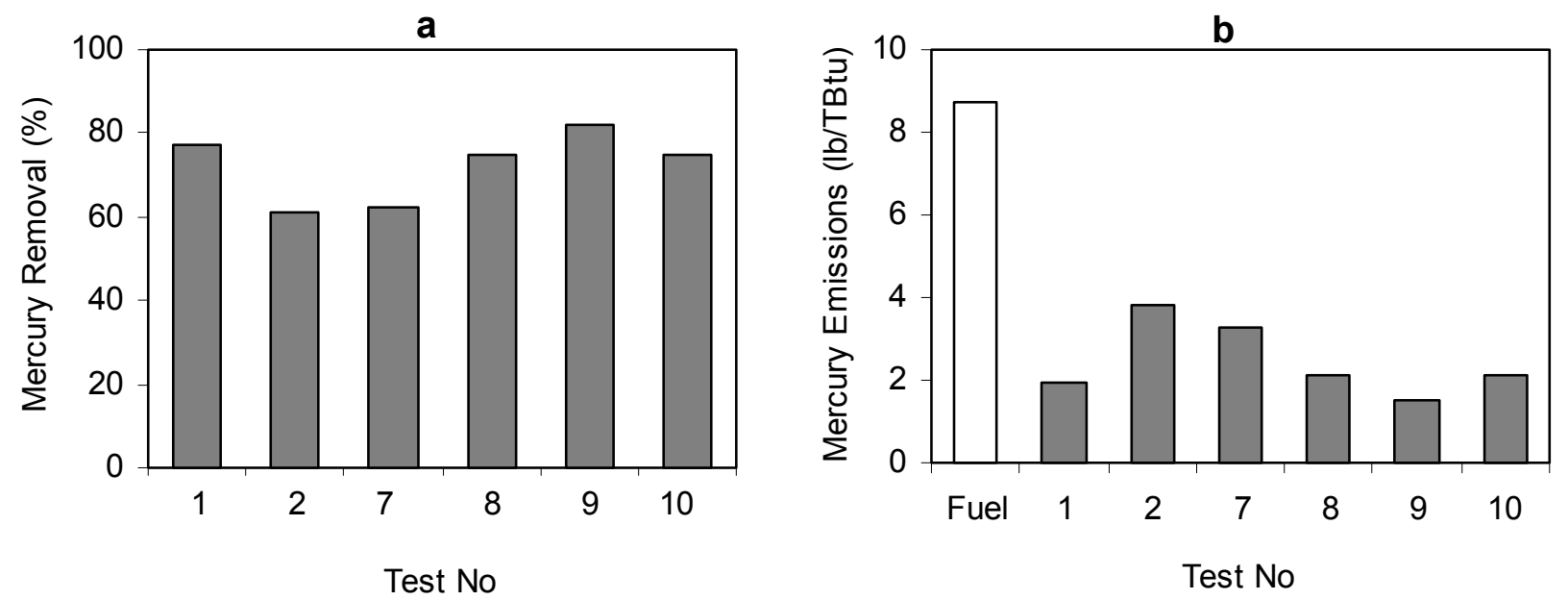

Figure 40. Mercury reduction efficiencies (a) and $\mathrm{Hg}$ emissions (b) during testing on September 20-24.

Results of Hg CEM measurements on September 24-27 for coal firing are shown in Figure 41. On September 26 at about 4 am Unit 2 was brought down for emergency repairs. Unit 2 was brought back on line at about $10 \mathrm{am}$.

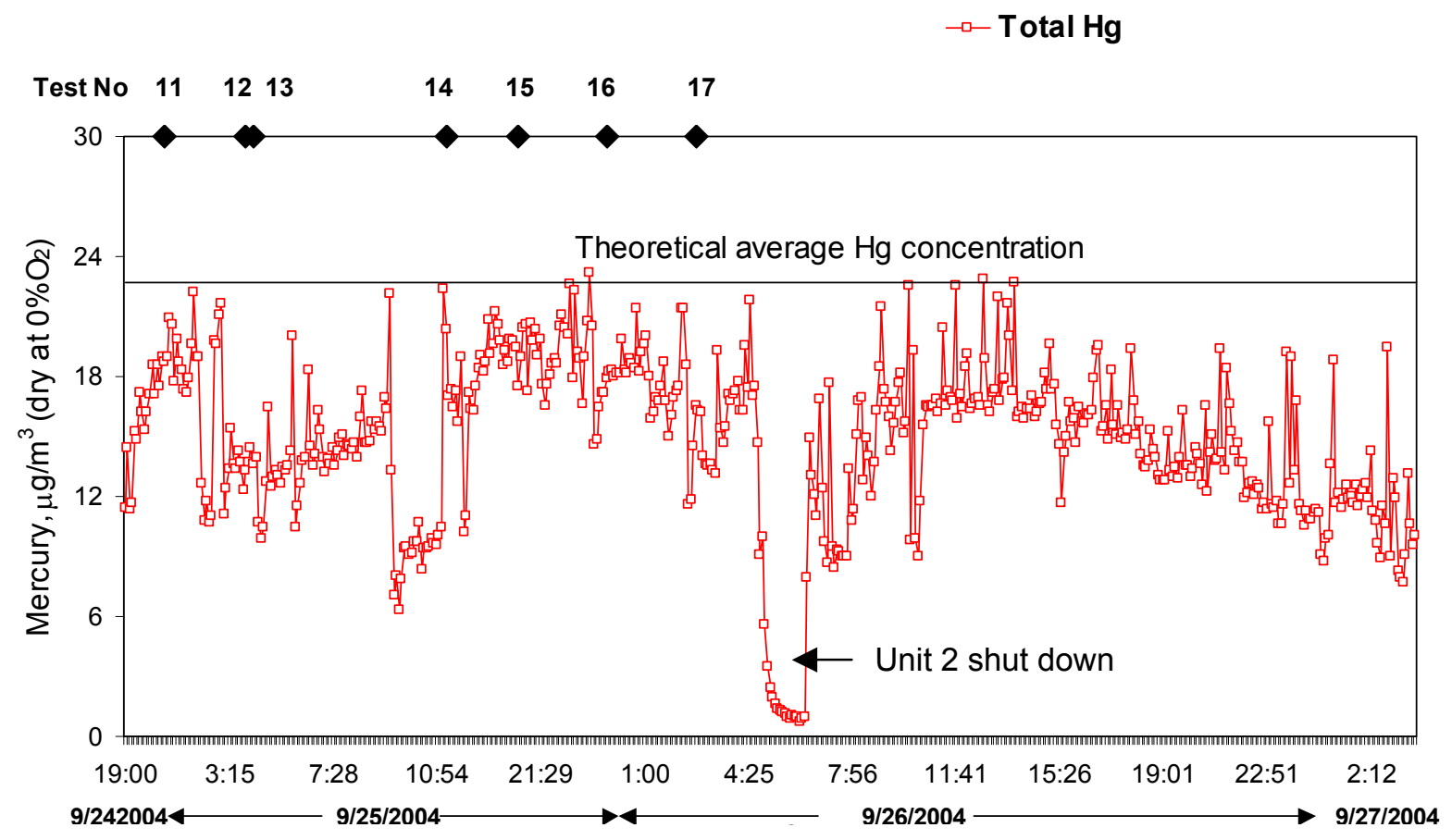

Figure 41. Results of CEM measurements for coal firing on September 24-27. 
Figure 42 shows $\mathrm{Hg}$ reduction and $\mathrm{Hg}$ emissions for coal firing. Figure 42 demonstrates that $\mathrm{Hg}$ reduction for coal firing was less than $40 \%$. It should be noted that the lowest ESP temperature in the coal firing tests was $280^{\circ} \mathrm{F}$, while in blend firing tests it was $270^{\circ} \mathrm{F}$. The highest LOI in coal firing was $5.4 \%$, about $50 \%$ of that in blend firing.
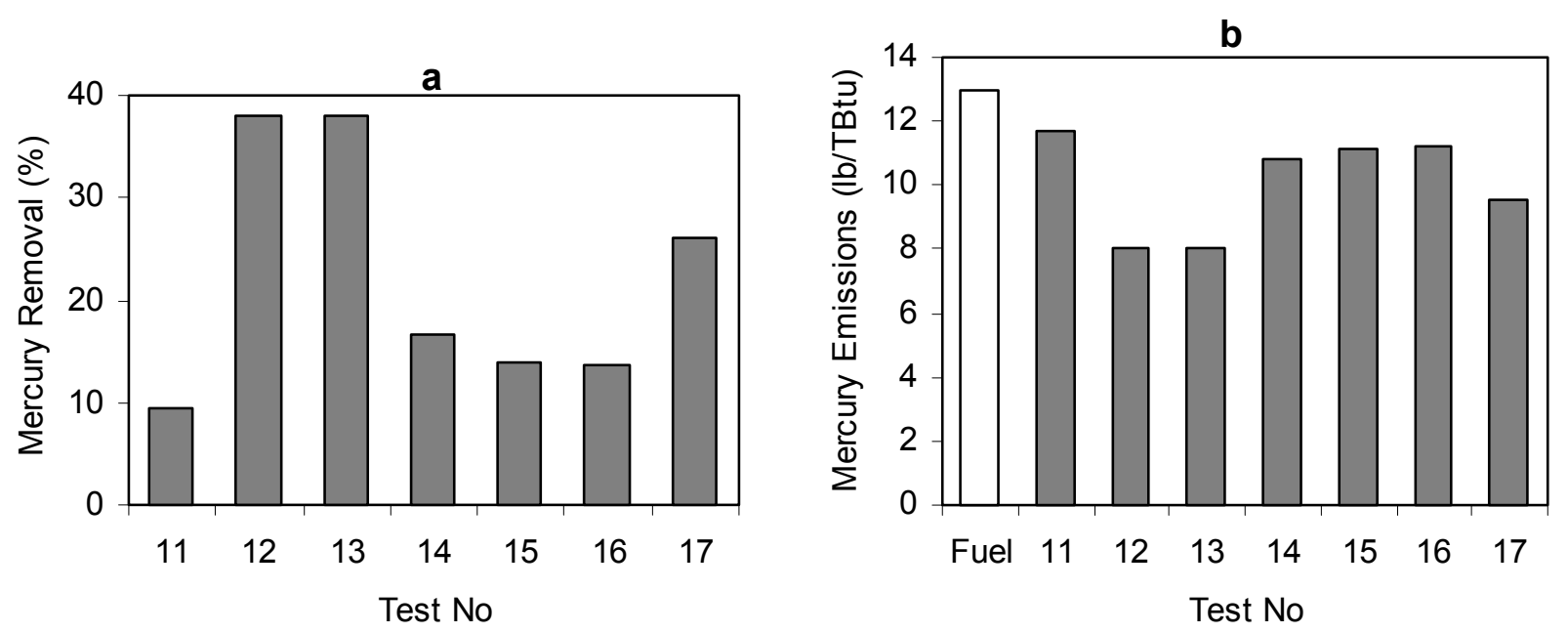

Figure 42. Mercury reduction efficiencies (a) and $\mathrm{Hg}$ emissions for coal firing.

Figure 43 shows $\mathrm{Hg}$ reduction and $\mathrm{Hg}$ emissions at the stack for coal firing measured by the FSTM method. Figure 40a demonstrates that combined $\mathrm{Hg}$ reduction across ESP wet FGD in Unit 2 is about $80 \%$. Figure $43 \mathrm{~b}$ shows uncontrolled $\mathrm{Hg}$ emissions calculated from $\mathrm{Hg}$ content in coal and $\mathrm{Hg}$ emissions at the stack. Figure $43 \mathrm{~b}$ demonstrates that $\mathrm{Hg}$ emissions at the stack for coal firing are below $2.6 \mathrm{lb} /$ TBtu. 

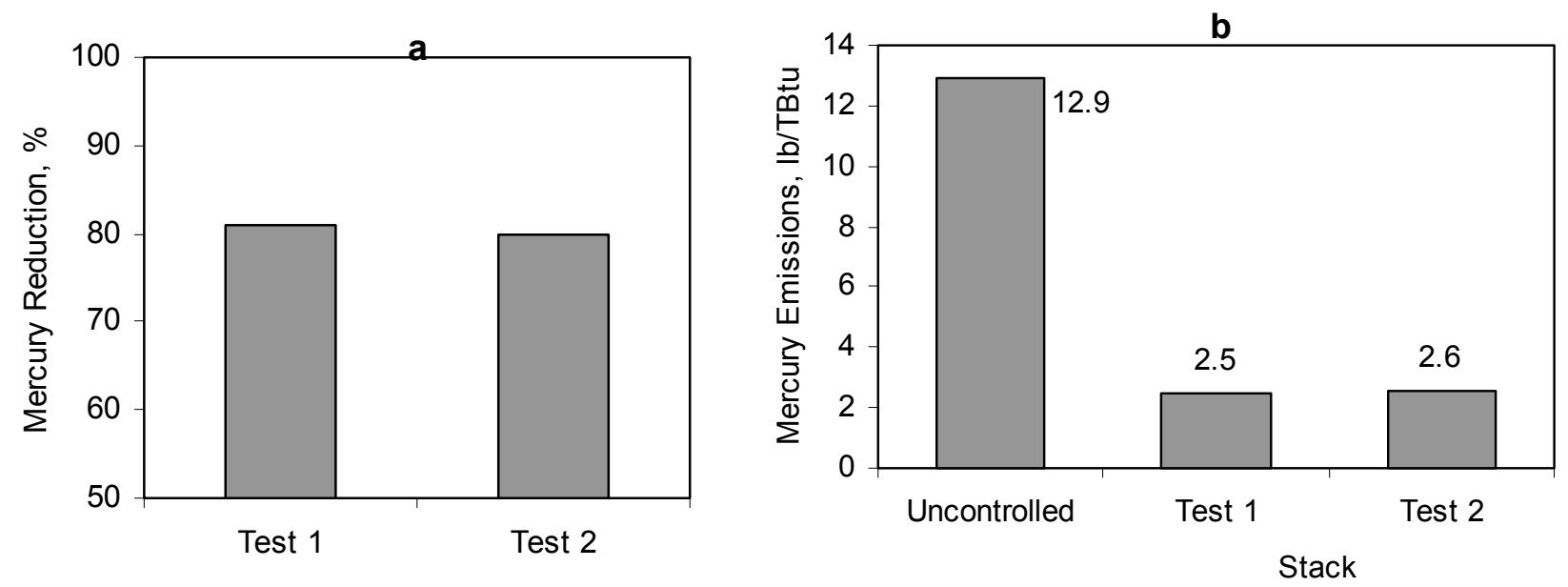

Figure 43. Mercury reduction efficiencies (a) and $\mathrm{Hg}$ emissions (b) at the stack for coal firing.

Reburning optimization also improved the efficiency of $\mathrm{NO}_{\mathrm{x}}$ reduction. $\mathrm{NO}_{\mathrm{x}}$ emissions in Unit 2 prior to reburning retrofit were $0.44 \mathrm{lb} / \mathrm{MBtu}$. Typically, NOx emissions in Unit 2 under reburning conditions were 0.18-0.20 lb/MBtu, about 57\% reduction. Table 12 shows that under deep staging conditions which were implemented to increase LOI minimum $\mathrm{NO}_{\mathrm{x}}$ emissions were 0.12-0.13 lb/MBtu, a 71\% reduction from uncontrolled emissions.

\subsection{Discussion and Comparison with Previous Data}

Testing suggested that ESP temperature had a significant effect on $\mathrm{Hg}$ removal. Figures 44 and 45 show the dependence of $\mathrm{Hg}$ removal efficiency on temperature for blend and coal firing as determined in $\mathrm{Hg}$ optimization and reburning tests described in Section 4.0. LOI in tests presented in Figures 44 and 45 was in the range of $9.5-10.5 \%$ and $2-3 \%$ for blend and coal firing, respectively. Testing demonstrated that ESP temperature reduction from $310^{\circ} \mathrm{F}$ to $270^{\circ} \mathrm{F}$ resulted in improvement in $\mathrm{Hg}$ reduction efficiency from about $40 \%$ to about $80 \%$ for blend firing. These results clearly demonstrate that controlling ESP temperature can improve the effectiveness of $\mathrm{Hg}$ absorption on high carbon fly ash.

Figure 46 shows dependence of $\mathrm{Hg}$ content in fly ash collected in ESP in Hg optimization tests on fly ash surface area. Figure 46 demonstrates that increase in fly ash surface area results in increase in fly ash $\mathrm{Hg}$ content. At the same fly ash surface area, $\mathrm{Hg}$ content in fly ash was higher for coal firing suggesting that fuel properties also affect $\mathrm{Hg}$ removal. Figure 46 also demonstrates 
that dependence of $\mathrm{Hg}$ content in fly ash on surface area is steeper for coal than that for blend firing.

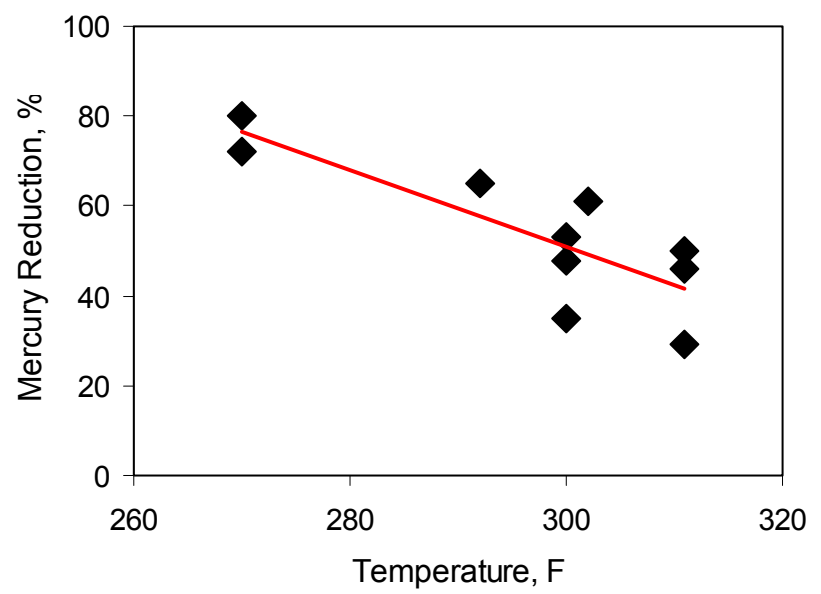

Figure 44. Dependence of $\mathrm{Hg}$ removal efficiency on temperature for blend firing.

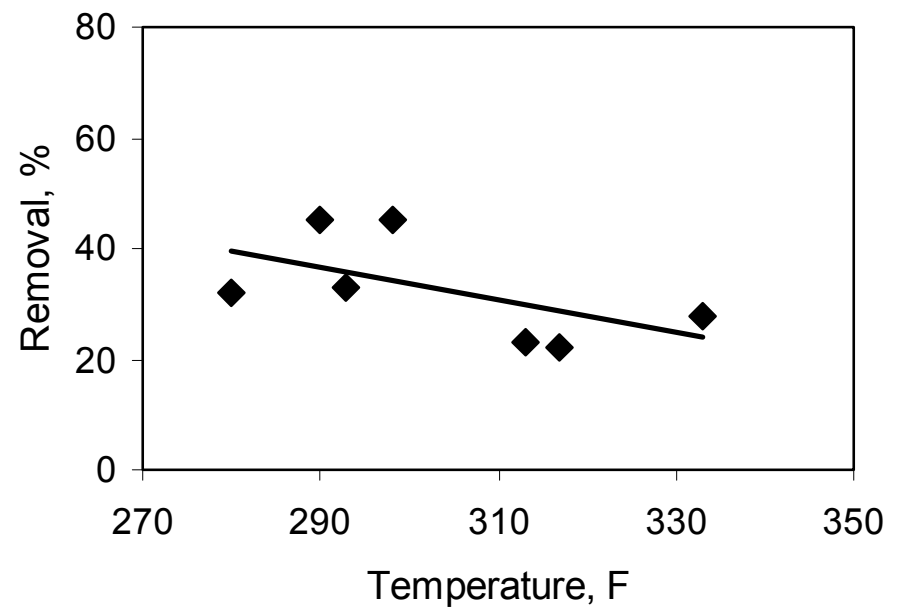

Figure 45. Dependence of $\mathrm{Hg}$ removal efficiency on temperature for coal firing. 


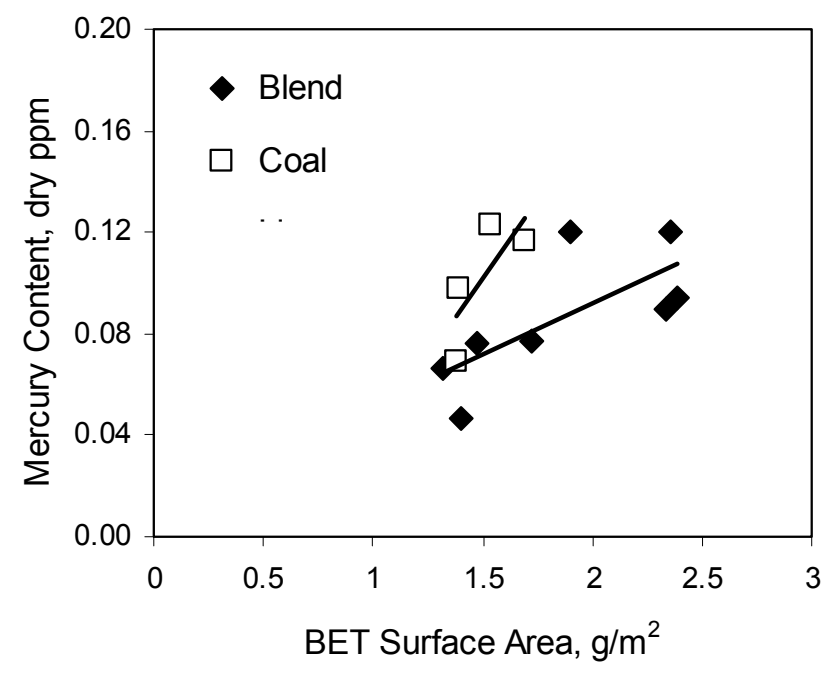

Figure 46. Dependence of $\mathrm{Hg}$ concentration in fly ash on fly ash surface area.

Testing demonstrated that under optimized reburning conditions Hg removal by fly ash was in the range of 60-80\% for blend firing. Thus, project goal of $80 \% \mathrm{Hg}$ control was demonstrated. The two most important parameters that affect efficiency of $\mathrm{Hg}$ removal are carbon in ash content and ESP temperature. The $80 \% \mathrm{Hg}$ control was achieved for LOI in the range of $10-11 \%$ and ESP temperature in the range of $270-285^{\circ} \mathrm{F}$. Since carbon in ash content is affected by combustion conditions and fuel reactivity, fuel properties should be also considered when evaluating potential efficiency of "naturally occurring” Hg capture on fly ash. 


\subsection{Project Summary}

In this project EER conducted a preliminary field evaluation of the integrated approach for $\mathrm{Hg}$ and $\mathrm{NO}_{\mathrm{x}}$ control. The integrated $\mathrm{Hg} / \mathrm{NO}_{\mathrm{x}}$ control method utilized coal reburning (injection of reburning coal and overfire air) and ESP to capture the fly ash. The approach enhanced the "naturally occurring" Hg capture by fly ash through combustion optimization, increasing carbon in ash content, and lowering ESP temperature. Other benefits of the approach included reduced $\mathrm{NO}_{\mathrm{x}}$ emissions, improved boiler performance, increased heat efficiency, and minimized CO emissions as a result of combustion optimization.

The evaluation took place in Green Station Units 1 and 2 located near Henderson, Kentucky and operated by Western Kentucky Energy. Units 1 and 2 are sister units with similar boiler parameters and unit configurations. They are equipped with cold-side ESPs and a wet scrubber. Green Station Units 1 and 2 typically fire two types of fuel: a bituminous coal and a blend of bituminous coals based on availability. Mercury content in the individual coal is typically higher than that in the blend.

The program focused on optimizing combustion conditions and ESP temperature to improve $\mathrm{Hg}$ removal across the ESP. No efforts were made to improve $\mathrm{Hg}$ reduction across the wet scrubber. Project goal was to demonstrate $80 \% \mathrm{Hg}$ control downstream of ESP.

The program comprised field and pilot-scale tests and engineering studies, and consisted of five tasks. The approach to optimizing the reburning system for $\mathrm{Hg}$ control included pilot-scale testing to determine effects of process conditions and fuel composition on $\mathrm{Hg}$ removal, engineering evaluation to determine boiler operating conditions that would allow to achieve optimum conditions for $\mathrm{Hg}$ removal, and Unit 2 optimization for $\mathrm{Hg}$ control. Pilot-scale testing demonstrated that $\mathrm{Hg}$ removal improved with LOI increase and ESP temperature decrease. Testing of $\mathrm{Hg}$ emission in Unit 2 confirmed pilot-scale observations and demonstrated $80 \% \mathrm{Hg}$ reduction downstream of ESP at optimized conditions.

Project results can be summarized as follows:

1. Testing of $\mathrm{Hg}$ emissions in Unit 2 without reburning system in operation and at minimum OFA demonstrated that efficiencies of $\mathrm{Hg}$ reductions downstream of ESP for coal and blend firing were $30-40 \%$. However, since $\mathrm{Hg}$ content in the blend was lower than that in the coal, $\mathrm{Hg}$ emissions were lower for blend firing. Mercury emissions at the ESP outlet were 5.8-6.9 $\mathrm{lb} /$ TBtu and 2.7-3.7 lb/TBtu for coal and blend firing, respectively. 
2. Testing demonstrated that OFA system operation at $22 \%$ air resulted in $10 \%$ incremental increase in $\mathrm{Hg}$ removal efficiency at ESP outlet.

3. Testing demonstrated that about $80 \%$ of $\mathrm{Hg}$ at the ESP outlet was present in the oxidized form.

4. Pilot-scale testing in a $300 \mathrm{~kW}$ Boiler Simulator Facility was conducted to determine effects of process conditions and fuel composition on $\mathrm{Hg}$ removal. Testing focused on determining effects of the following factors on Hg removal: (a) fuel composition, (b) carbon in ash content, and (c) ESP temperature. Testing demonstrated that $\mathrm{Hg}$ removal improved with LOI increase and ESP temperature decrease. Results of pilot-scale testing suggested that $80 \% \mathrm{Hg}$ control could be achieved at $\mathrm{LOI} \geq 8 \%$ and ESP temperatures $\leq 300^{\circ} \mathrm{F}(420 \mathrm{~K})$.

5. Testing of $\mathrm{Hg}$ emissions in Units 1 and 2 under reburning conditions confirmed that $\mathrm{Hg}$ emissions decreased with LOI increase and ESP temperature decrease. Testing demonstrated that maximum $\mathrm{Hg}$ reduction downstream of ESP was $40-45 \%$ at ESP temperature higher than $300^{\circ} \mathrm{F}$ and $60-80 \%$ at ESP temperatures lower than $300^{\circ} \mathrm{F}$.

6. The $80 \% \mathrm{Hg}$ control downstream of ESP in Unit 2 was achieved for blend firing for LOI in the range of $10-11 \%$ and ESP temperature in the range of $270-285^{\circ} \mathrm{F}$.

7. Maximum LOI achieved with coal firing was $6 \%$, about half that of blend firing. As a result of lower LOI, maximum $\mathrm{Hg}$ reduction downstream of ESP for coal firing was $40 \%$. Since carbon in ash content is affected not only by combustion conditions but also by fuel reactivity, fuel properties should be also considered when evaluating efficiency of "naturally occurring" $\mathrm{Hg}$ capture on fly ash.

8. Testing demonstrated that efficiency of $\mathrm{Hg}$ removal across the FGD was in the range of $65-$ $70 \%$. Reduction in concentration of the oxidized $\mathrm{Hg}$ was about $90 \%$. However, about $20 \%$ of the oxidized $\mathrm{Hg}$ was reduced to elemental $\mathrm{Hg}$ across the scrubber. Most $\mathrm{Hg}$ at the stack was present in the elemental form.

9. Mercury emissions at the Unit 2 stack were lower for blend firing due to the lower $\mathrm{Hg}$ content in the blend. Mercury emissions at the stack at tested conditions were in the range of 1.8-3.0 $\mathrm{lb} /$ TBtu and 1.0-1.5 lb/TBtu for coal and blend firing, respectively.

10. Under optimized reburning conditions $\mathrm{NO}_{\mathrm{x}}$ emissions were reduced from uncontrolled 0.44 lb/MBtu to $0.13 \mathrm{lb} /$ MBtu. 


\subsection{Acknowledgement}

The authors of this report would like to acknowledge support of Steve Noland, Senior Environmental Scientist at LG\&E Energy (WKE parent company) who provided general coordination of the mercury testing program at Green Station; Kevin West, Green Station Operation Supervisor who was closely involved in daily activities during field testing, and all of Green Station Control Room Operators and Shift Supervises who were involved with the program. We appreciate dedication of EER combustion research technicians (Andy Furlong, Brian Jacobs, and Robert Elliott) and Loc Ho, Test Engineer, who significantly contributed to this project by generating high quality combustion test data. We also acknowledge program support by U.S. DOE NETL personnel including Dr. Peter Botros, Contracting Office Representative, Lynn Bricket, Project Manager, and Tomas Feeley III, Technology Manager of Environmental \& Water Resources Program.

\subsection{Bibliography}

1. Lissianski, V.V., Zamansky, V.M., Maly, P.M., Seeker, R., Folsom, B., and Koppang, R. "Novel Technology for Multiple Pollutant Control", The A\&WMA Specialty Conference on Mercury Emissions: Fate, Effects, and Control, August 21-23, Chicago, IL 2001.

2. Lissianski, V.V., Zamansky, V.M., Maly, P.M., and Seeker, R.W. "Integration of Combustion Modifications with Mercury Control”, Air Quality III Conference, Washington, DC, September $11,2002$.

3. Lissianski, V.V., Ho, L., Maly, P., Seeker, W.R., and Zamansky, V.M. "Integration of Combustion Modifications with Mercury Control", The 2003 EUEC, Tucson, AZ, January 27-30, 2003

4. Final technical Report to ICCI, Project 98-1/1.2B-2, W. A. Rosenhoover, CONSOL Inc.

5. L. Lindau, M. Durham, J. Bustard, C. Martin "Mercury: myths and realities", Modern Power Systems, March 2003, p. 30

6. Bloom, N.S. (1993) "Mercury Speciation in Flue Gases: Overcoming the Analytical Difficulties." Managing Hazardous Air Pollutants: State of the Art. (W. Chow and K. Connor, Eds.), EPRI TR-10189, Lewis Publishers, Boca Raton, USA p. 148. 
7. Bloom, N.S., Prestbo E.M., Hall B. and von der Geest E.J. (1995) "Determination of Atmospheric Hg by Collection on Iodated Carbon, Acid Digestion and CVAFS Detection," Water, Air, and Soil Pollution. 80: 1315-1318.

8. DOE, National Energy Technology Laboratory (2001) "Comparison of Sampling Methods to Determine Total and Speciated Mercury in Flue Gas," CRADA 00-F038 Final Report DOE/NETL-2001/1147, Pittsburgh, USA. 